\title{
Current State of Diabetes Mellitus Prevalence, Awareness, Treatment, and Control in Latin America: Challenges and Innovative Solutions to Improve Health Outcomes Across the Continent
}

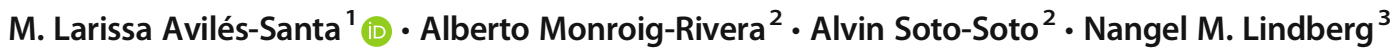 \\ Accepted: 10 September 2020 \\ (C) This is a U.S. government work and not under copyright protection in the U.S.; foreign copyright protection may apply 2020
}

\begin{abstract}
Purpose of Review Latin America is the scenario of great inequalities where about 32 million human beings live with diabetes. Through this review, we aimed at describing the current state of the prevalence, awareness, treatment, and control of diabetes mellitus and completion of selected guidelines of care across Latin America and identify opportunities to advance research that promotes better health outcomes.

Recent Findings The prevalence of diabetes mellitus has been consistently increasing across the region, with some variation: higher prevalence in Mexico, Haiti, and Puerto Rico and lower in Colombia, Ecuador, Dominican Republic, Peru, and Uruguay. Prevalence assessment methods vary, and potentially underestimating the real number of persons with diabetes. Diabetes unawareness varies widely, with up to $50 \%$ of persons with diabetes who do not know they may have the disease. Glycemic, blood pressure, and LDL-C control and completion of guidelines to prevent microvascular complications are not consistently assessed across studies, and the achievement of control goals is suboptimal. On the other hand, multiple interventions, point-of-care/rapid assessment tools, and alternative models of health care delivery have been proposed and tested throughout Latin America.

Summary The prevalence of diabetes mellitus continues to rise across Latin America, and the number of those with the disease may be underestimated. However, some local governments are embedding more comprehensive diabetes assessments in their local national surveys. Clinicians and public health advocates in the region have proposed and initiated various multi-level interventions to address this enormous challenge in the region.
\end{abstract}

Keywords Latin America $\cdot$ Diabetes prevalence $\cdot$ Diabetes treatment $\cdot$ Control $\cdot$ Diabetes complications $\cdot$ Interventions $\cdot$ Health care

\section{Introduction}

Within the last couple of decades, non-communicable diseases (NCDs) have gained worldwide attention, especially in

This article is part of the Topical Collection on Diabetes Epidemiology

M. Larissa Avilés-Santa

avilessantal@nih.gov

1 Division of Extramural Scientific Programs, Clinical and Health Services Research at the National Institute on Minority Health and Health Disparities, Bethesda, MD, USA

2 Ponce Health Sciences University, Ponce, Puerto Rico

3 Kaiser Permanente Health Research Center, Portland, Oregon, USA low- and middle-income countries (LMIC), where they have been increasingly recognized and prevalent $[1,2]$. Among the NCDs, diabetes mellitus has become a global health challenge $[1,3,4]$. Type 2 diabetes mellitus - the most common form of diabetes - due to its rather silent disruption may be a current uninvited companion to over 465 million persons worldwide. In 2019, it was estimated that the number of persons with diabetes in Latin America (LatAm) was 31.6 million [5, 6] and is predicted that by 2030 , the number will increase to 40.2 million, and to 49.1 million by 2045 [6].

Because of its multi-organ and multi-system impact, diabetes has been associated with both acute and long-term complications that affect not only health care needs and costs but also wellbeing and productivity $[7,8]$. Within the last decade, it has also been recognized as one of the leading causes of death in some LatAm countries [9-15] and an important risk factor 
for cardiovascular diseases (CVD), which is the leading cause of death in LatAm [14, 16].

Far from being a monolithic group, the LatAm population is highly heterogeneous, with various populations reflecting diverse genetic ancestry, ethnicity, culture of origin, sociopolitical contexts, environmental exposures, and beliefs and practices $[17,18]$. Levels of inequality in LatAm remain among the highest in the world [19-22]. All these factorscoupled with biological susceptibility, income, education, access health care, cultural influences on nutrition, health, selfimage, and self-care-influence the development of diabetes in LatAm.

We conducted a review of the most current publications on the state of prevalence, awareness, treatment, and control of diabetes mellitus across LatAm. By laying out a detailed accounting of what is known, we aim to identify population, clinical, and health care needs, and opportunities for future research studies and potential interventions.

\section{Literature Search and Review}

We conducted the search using the PubMed electronic database as the primary scientific literature source. LatAm was defined as the countries in the Western hemisphere which were previously colonized by Spain, Portugal, or France. A combination of keywords was used to define the scope of the searches: diabetes prevalence, awareness, treatment, control, guidelines of care, adherence, retinopathy, nephropathy, neuropathy, foot care, fundoscopic exam, and urine albumin, and searched under LatAm and by each individual country. Hispanics/Latinos living in the USA were not included in the search.

We limited the search to publications since 2000 to reflect the most recent research on the prevalence of diabetes across LatAm countries, assessments of awareness, treatment, and control of diabetes (glycemic control), blood pressure and low-density lipoprotein cholesterol (LDL-C), and adherence to guidelines for care recommended by the American Diabetes Association (ADA) [23-25] and the Latin American Diabetes Association (ALAD) [26], and specifically hemoglobin A1c (HbA1c) measurement, fundoscopic exam, foot exam, and urine albumin excretion test. We included literature written in English, Spanish, French, and Portuguese.

In addition to PubMed, when available, we manually searched each country's Ministry of Health and the Pan American Health Organization (PAHO) websites and accessed published and downloadable national health surveys performed during the selected timeframe. Since most available studies did not distinguish between type 1 and type 2 diabetes mellitus, our review is centered on diabetes mellitus (diabetes, henceforth) in general. Because their specific mechanisms of disease and clinical implications, gestational diabetes mellitus, and type 1 diabetes merit separate reviews.

\section{Prevalence of Diabetes Mellitus in Latin America}

The earliest contemporary reports on the prevalence of diabetes mellitus among adults throughout LatAm date from the 1950s and 1960s [27-29], when most countries were beginning to experience epidemiologic transitions [30, 31]. In 2001, Barceló reported an incidence of type 1 diabetes in LatAm in the range 0.1 cases/100,000 in Venezuela to 17.4 cases/ 100,000 in Puerto Rico [32]. However, the authors highlighted a handful of reports on the prevalence of type 2 diabetes and underlined the near absence of surveillance for the disease throughout the LatAm region [32].

From 2005 to 2020, the prevalence of diabetes mellitus across LatAm has been assessed within individual countries and through multinational studies [33-114] and ranged between 3 and $36.3 \%$ (Fig. 1, Table 1). In our review, some national surveys assessed the prevalence of diabetes via population representative samples [33, 36, 38, 40, 42-44, 47, 49, $55,60,61,65,66,68,72,85-87,89,91,96,98,105,107]$ and used similar population sampling methods (e.g., multi-stage, clustered, probabilistic sampling), whereas other studies focused on specific geographic regions or communities [34, $35,37,45,46,48-54,56-58,63,67,73-75,77,82-84$, 92-95, 102, 110-112], recruited participants from clinical settings $[51,59,62,69,95]$, or focused on specific age groups $[37,42,56-58,75,109,112]$. Also, the age range of the population surveyed - and consequently, age-adjustment estimates - varied among surveys.

Most of the studies (especially national surveys) reported the overall prevalence of diabetes without differentiating between type 1 and type 2 diabetes mellitus and many estimated the prevalence of the disease based on selfreport (being aware of having diabetes and/or taking antihyperglycemic medications) only. Some national surveys and independent studies estimated the prevalence based on the sum of self-report and identifying individuals without history of diabetes but hyperglycemia within the diabetes range [26, 115]. The latter group was considered to have "suspected," "undiagnosed," or "unknown" diabetes. Hyperglycemia within the diabetes range was assessed by measuring fasting blood or plasma glucose (FBG or FPG) only, FBG/FPG and 2-h oral glucose tolerance test (OGTT), FBG/FPG and hemoglobin A1c (HbA1c), HbAlc only, or the combination of FBG/FPG, OGTT, and HbAlc, or glucose levels in urine. Some studies measured capillary blood glucose (CBG), while most studies measured venous blood or plasma glucose. While multiple studies used the ADA/ALAD-recommended glucose/HbA1c cut points for 
Fig. 1 Prevalence of diabetes mellitus in Latin America Based on national surveys from 2000 to 2020. Prevalence data was extracted from national surveys, when available. Prevalence was estimated either by self-report of diabetes exclusively or in combination with glycemic tests. References next to each country's name in [brackets]

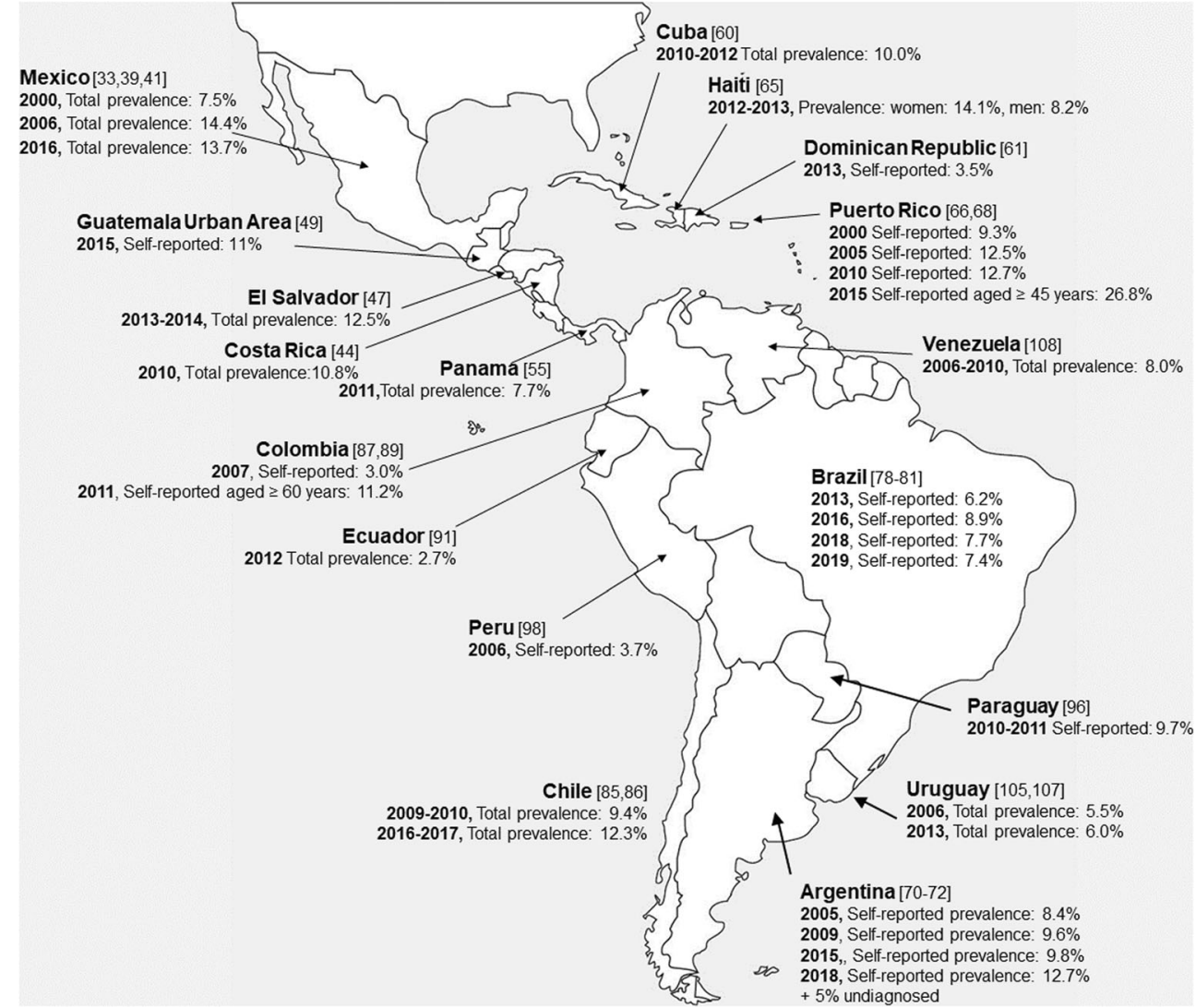

the diagnosis of diabetes [26, 115], some studies used different thresholds (e.g., fasting glucose $\geq 100 \mathrm{mg} / \mathrm{dL}$ (per $\mathrm{CBG}$ ), random blood glucose $\geq 140 \mathrm{mg} / \mathrm{dL}$, or random blood glucose $\geq 200 \mathrm{mg} / \mathrm{dL}$ ).

Although the differences in the methodology described above limit the ability to perform cross-sectional or trend comparisons among countries, we note several commonalities. During 2005-2020, some countries reported an increase in the prevalence of diabetes $[33,36,38-40,66,70-72,79,85$, $86]$, consistent with previously published reviews $[5,15,32$, 116-123]. Compared with the rest of the region, and as previously reported $[5,15,32,124,125]$, diabetes prevalence varies across the region, with higher prevalence in Mexico (13.7\%), Haiti (14.1\% in women and $8.2 \%$ in men), and Puerto Rico (12.5-12.7\% in the population aged $18 \geq$ years and $26.8 \%$ in the population aged $\geq 45$ years), and lower in Colombia (3.0\% in the population aged $18 \geq$ years, but $11.2 \%$ in age group $\geq 60$ years), Dominican Republic (3.5\%), Ecuador (2.7\%), Peru (3.7\%), and Uruguay (5.5-6.0\%) (Fig. 1 , Table 1). Multiple studies reported a greater prevalence of diabetes among women $[36,38,40,42,44,47,49-52,57,60$, $62,63,65,70,72,75,78,79,83-86,90,95,96,110,113]$, and with increasing age, especially over age 60 years $[33,36$, $44,47,50,55,69-72,78,80,81,86,91,93,110]$. Some studies reported an inverse relationship between diabetes and socioeconomic status (SES) $[33,79,103]$ or educational attainment [33, 44, 62, 63, 70, 72, 73, 75, 76, 78, 79, 86, 101]. Other studies reported a direct relationship between having health insurance and self-reported diabetes [42, 70, 97, 100], implying that persons who have health insurance - proxy of access to health care services - would be aware of their health issues and report them accordingly. This interaction also poses questions about not only the access to health care but also the timeliness and quality of the care, and health literacy (or the lack of) that persons in the lowest SES - and at the highest risk of diabetes - would experience. Some studies reported a lower prevalence of diabetes among indigenous populations [35, $48,74]$, with one study proposing that exposure to urbanicity was associated with an increased prevalence of diabetes among some indigenous communities [83]. Indeed, rural to urban migration (or living in rural compared with urban areas) has been associated with increased prevalence or risk of developing diabetes in Peru [126, 127], and multiple countries reported a lower diabetes prevalence in rural compared with urban settings [33, 39, 47, 60, 65, 89-91, 99, 103].

The number of epidemiological studies published since 2005 indicates greater public health awareness about diabetes mellitus across LatAm. Multiple countries have performed at least one national survey on chronic non-communicable diseases in which self-reported diabetes mellitus and/or elevated 


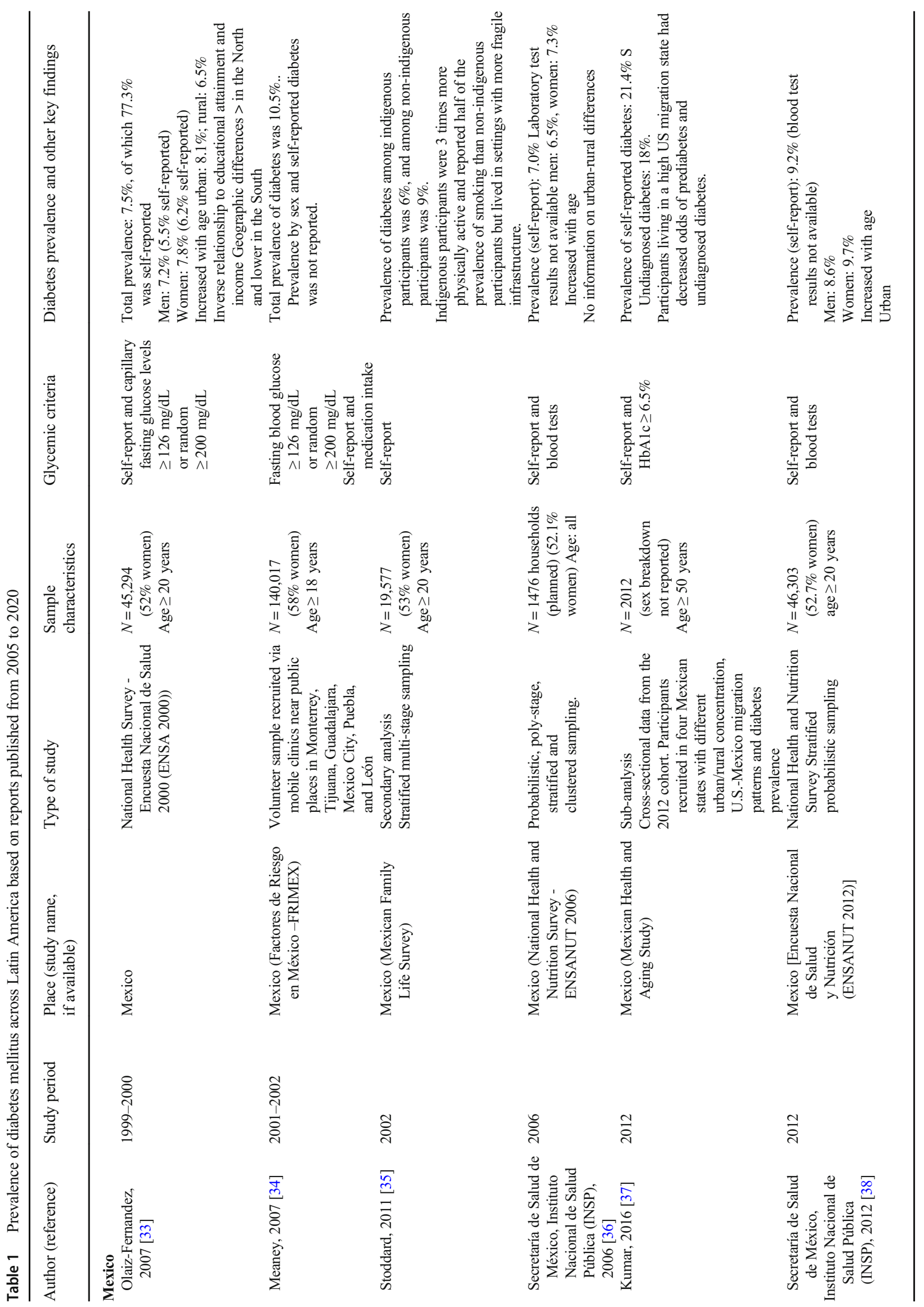




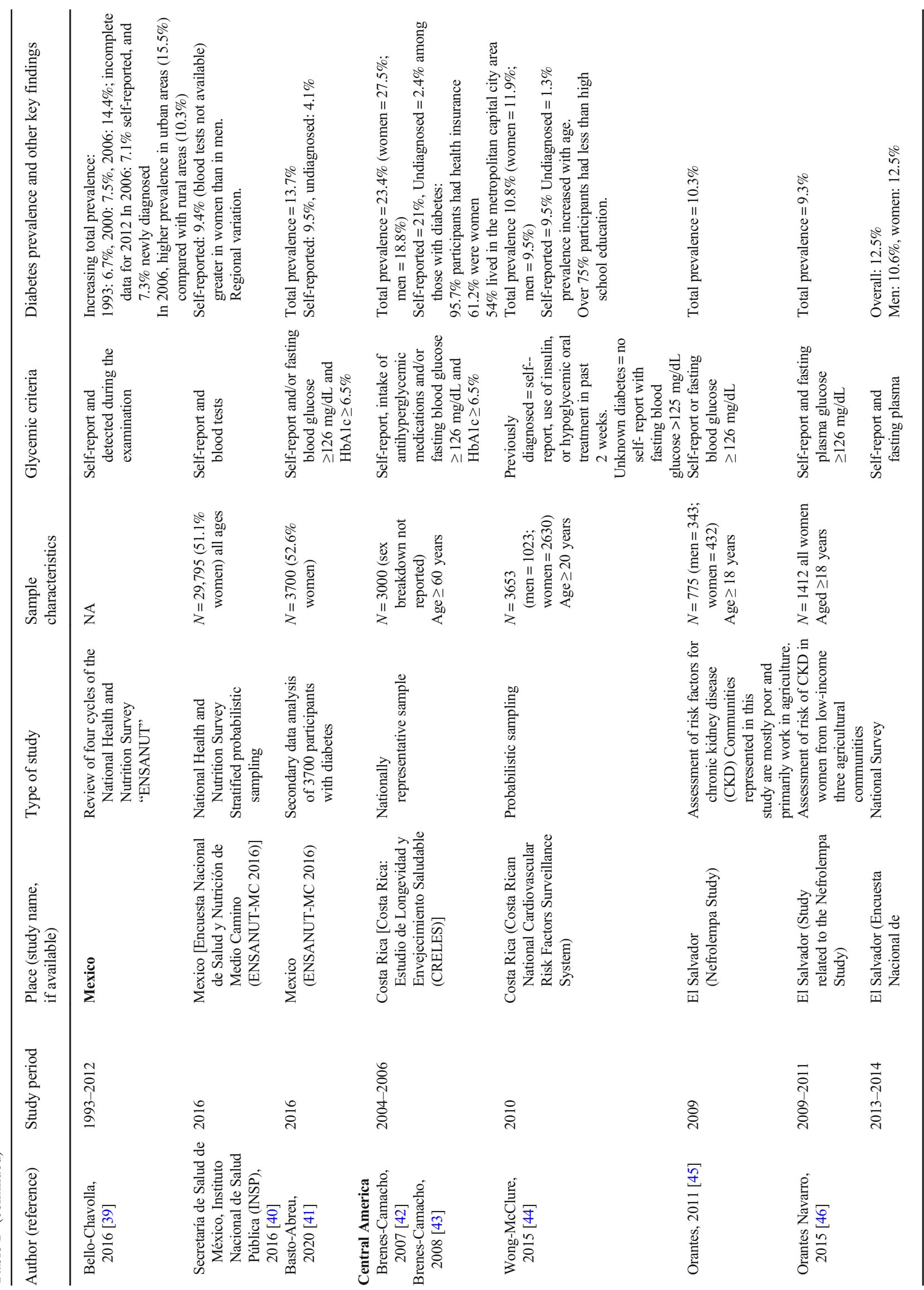




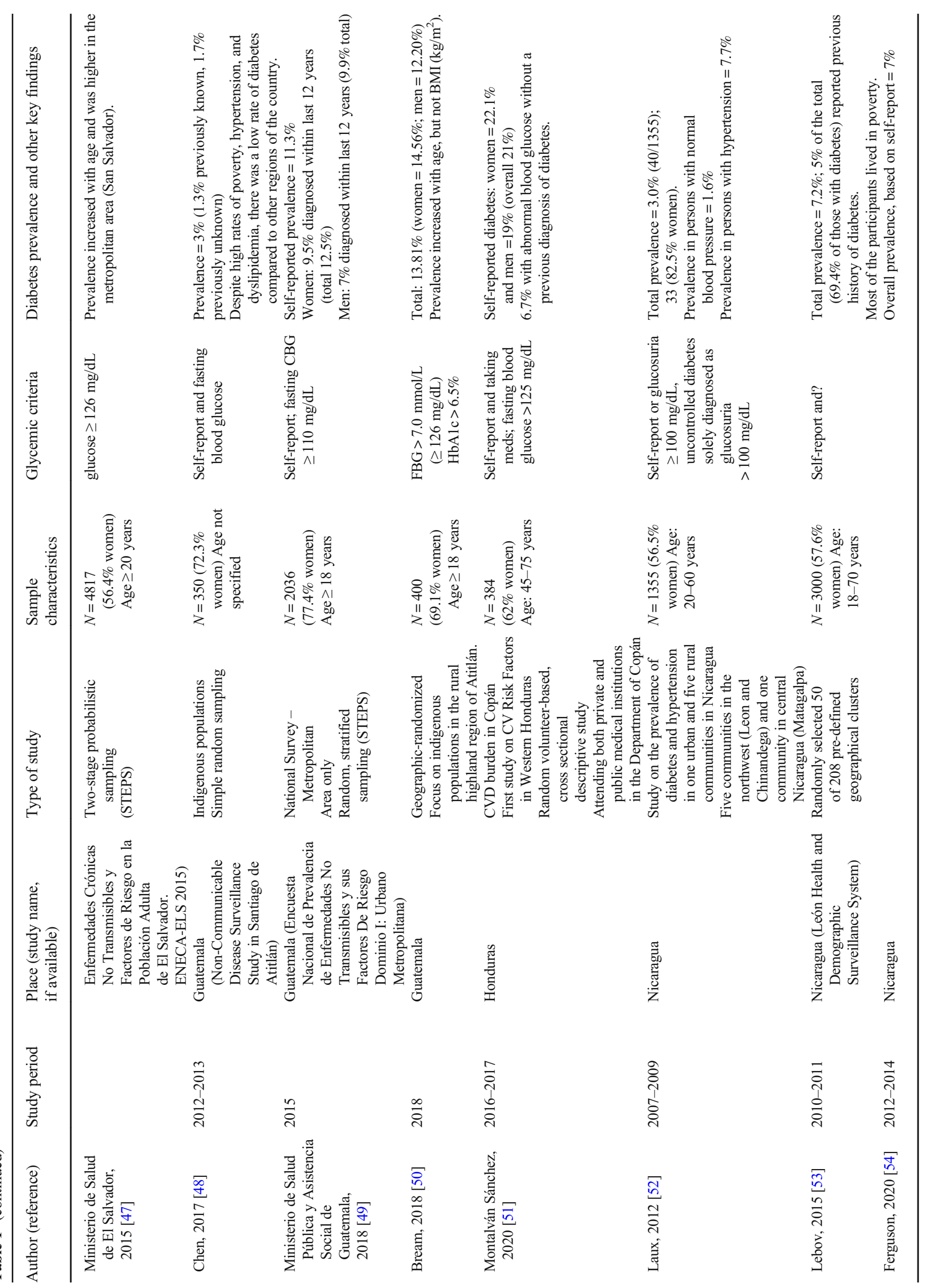




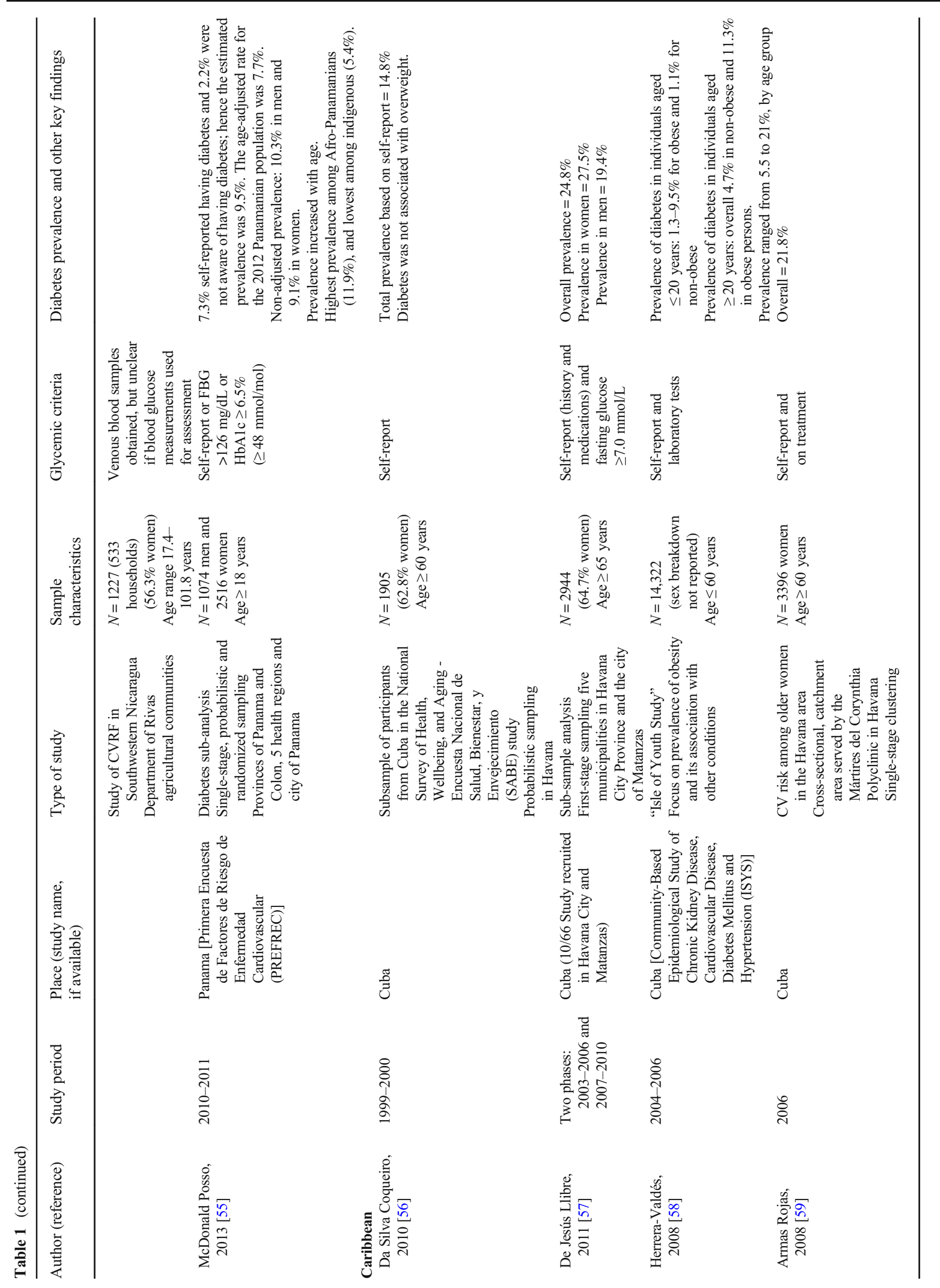




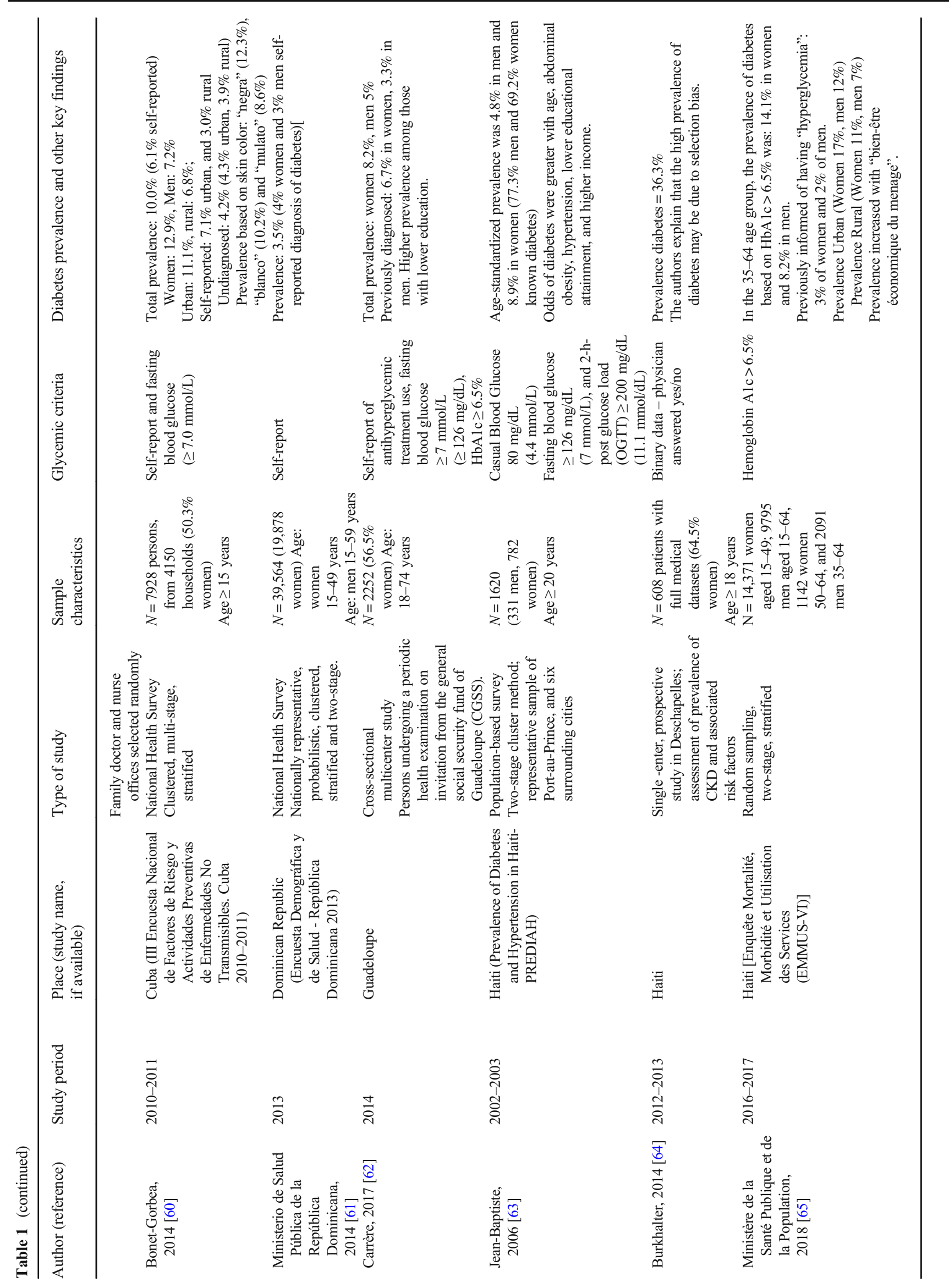









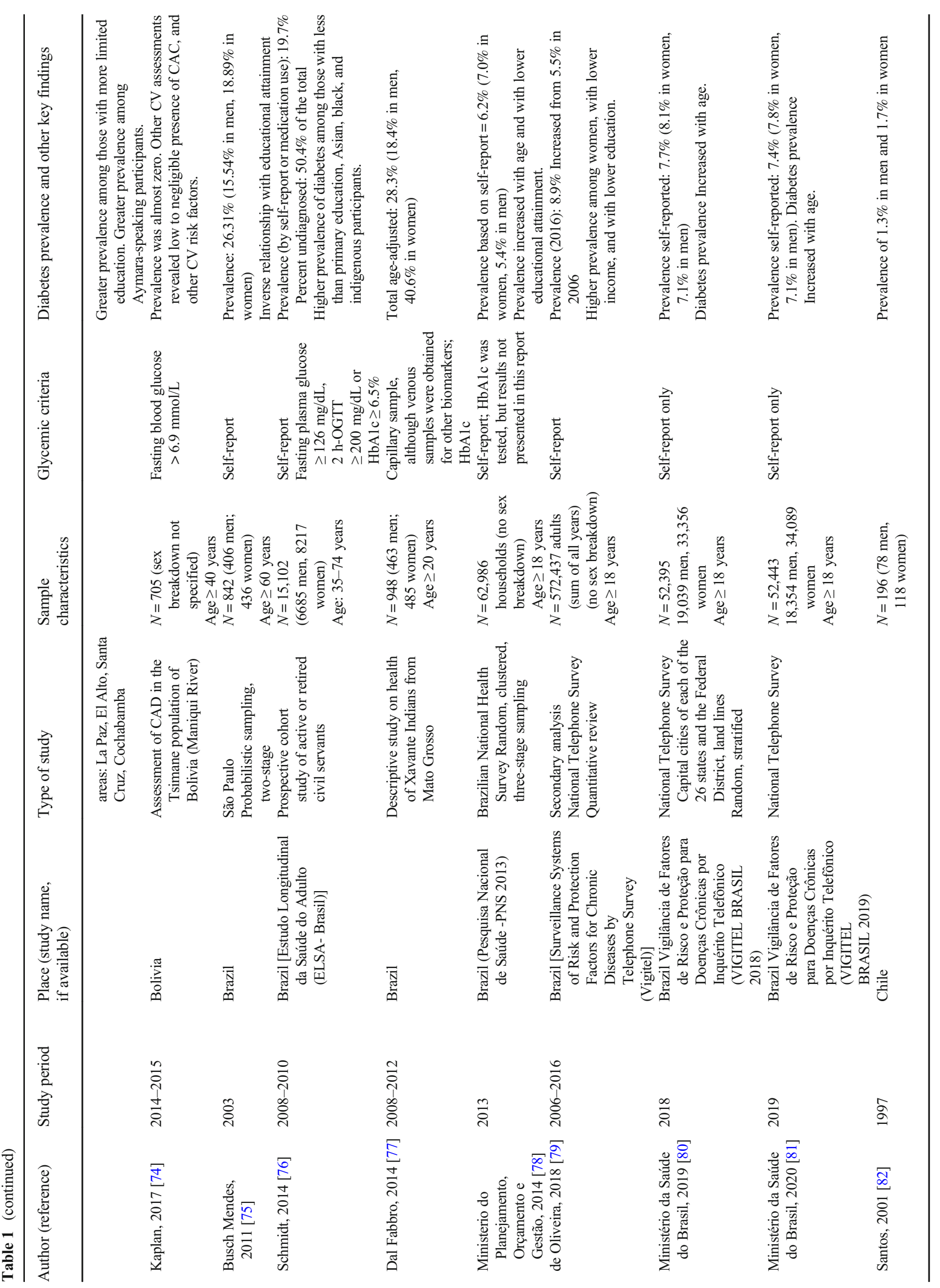




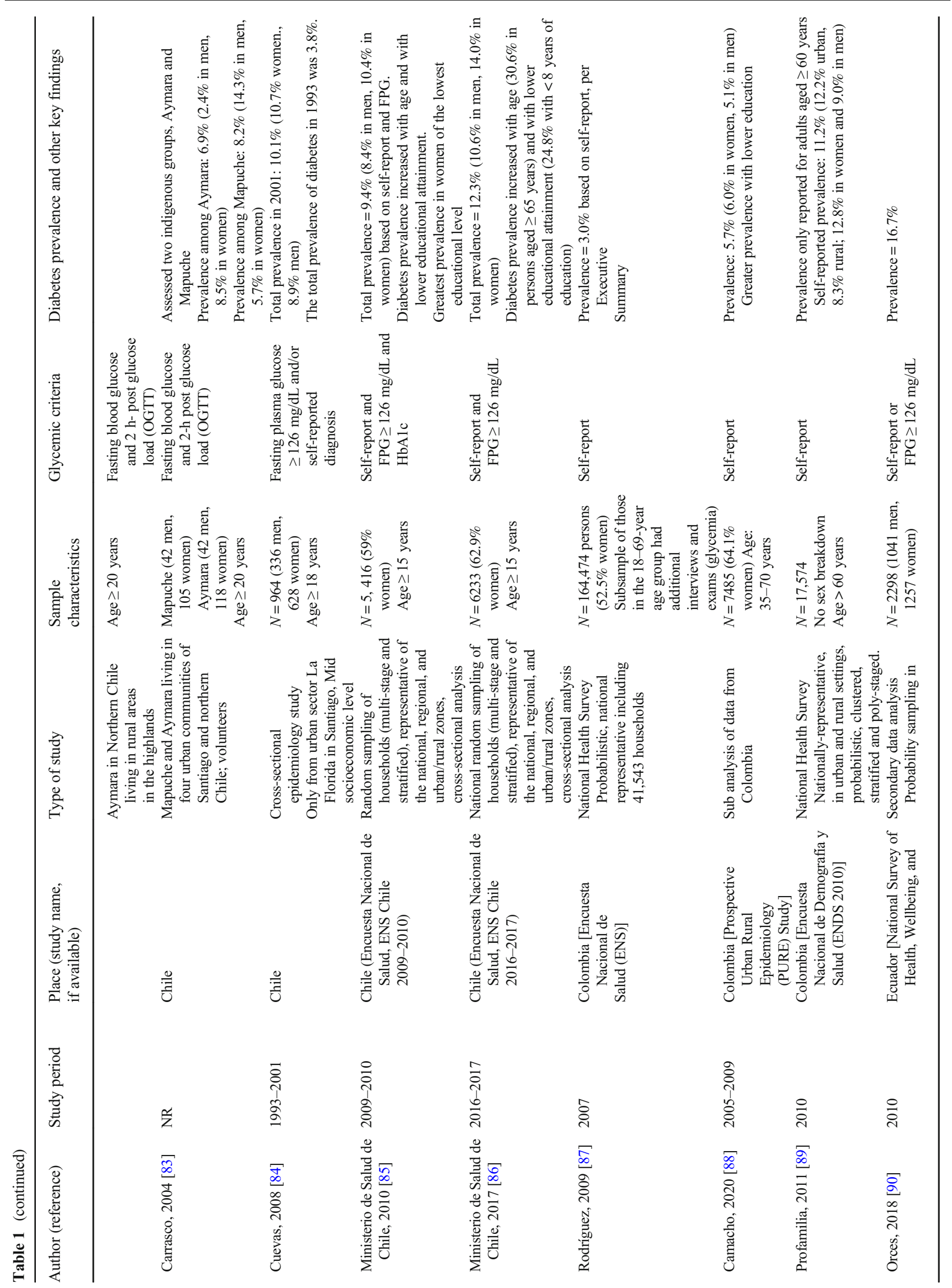




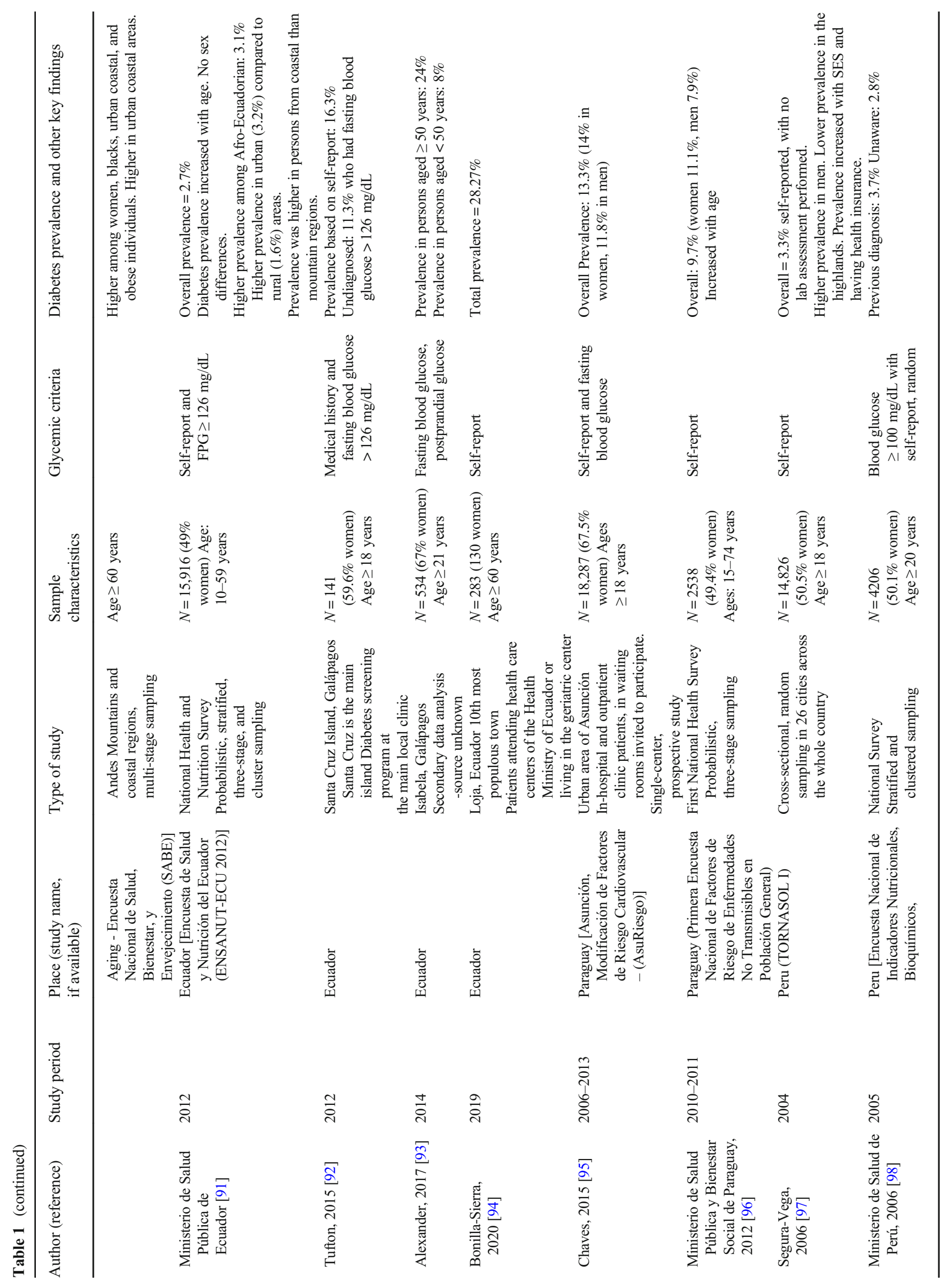




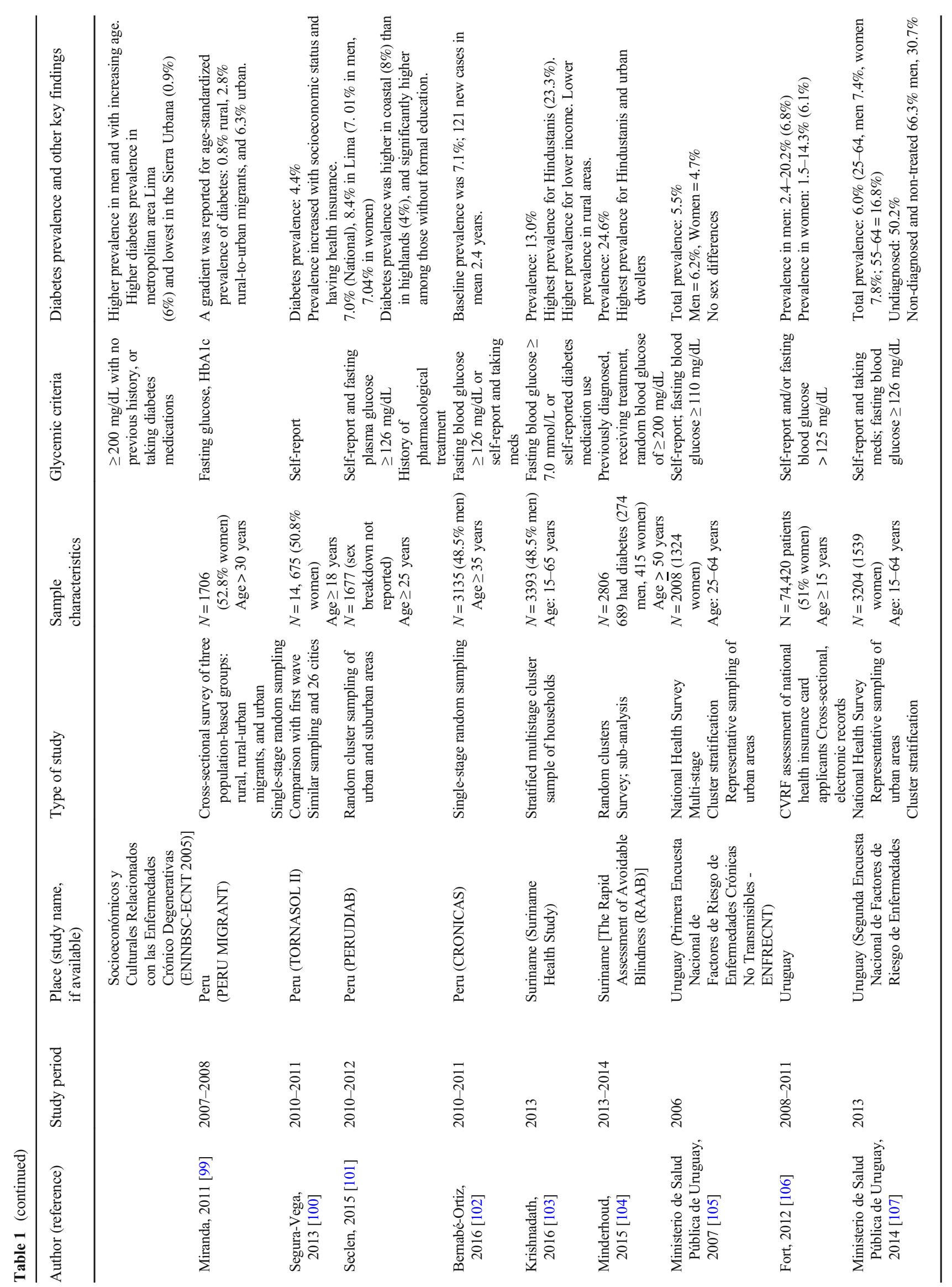




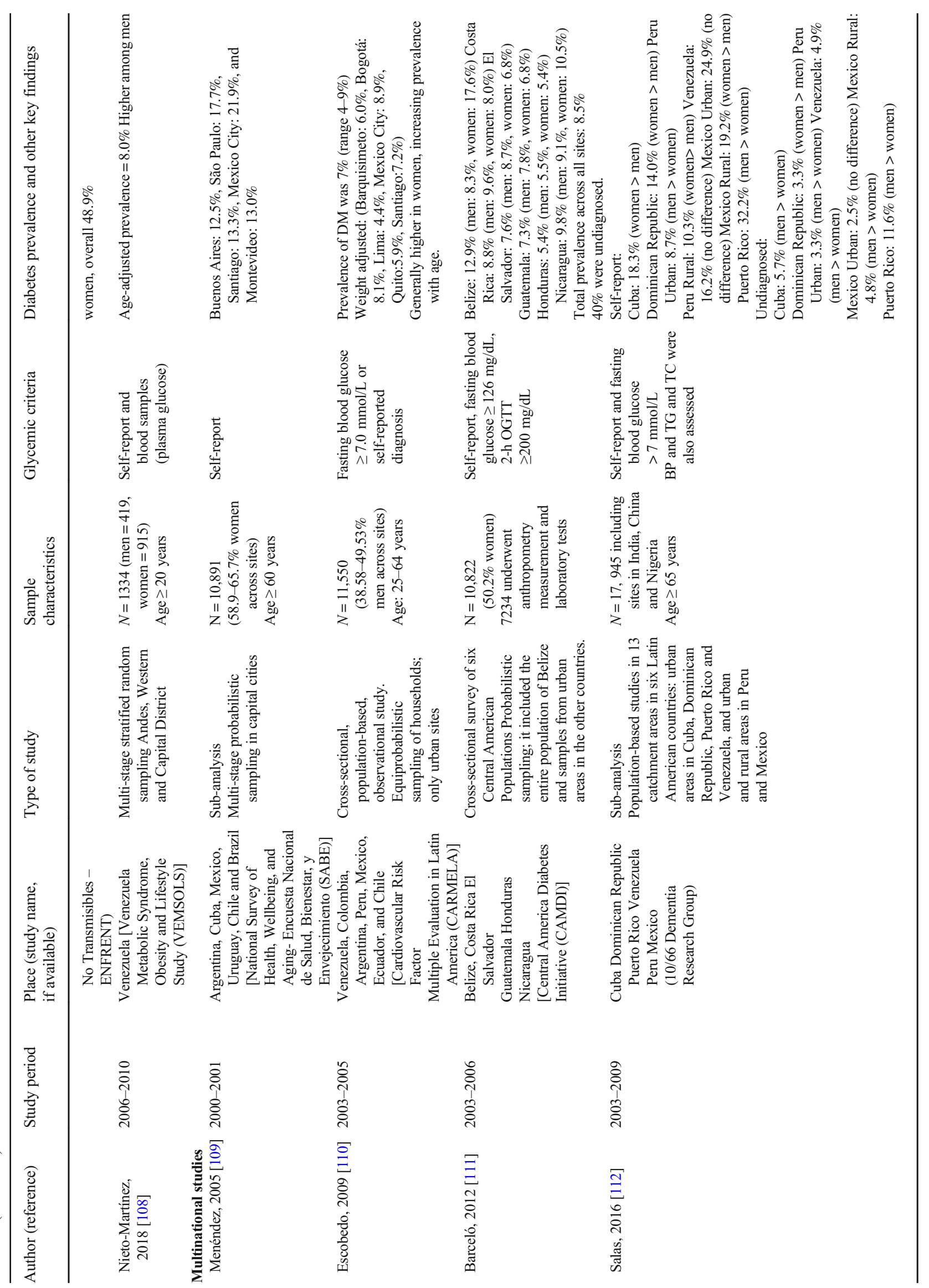


glycemia has been included (Table 1). Some surveys have also included at least one laboratory test (i.e., fasting or random blood glucose measurement or $\mathrm{HbAlc}$ ), which could identify individuals at risk of developing diabetes or those who may have it and are not aware of it. Because hyperglycemia may be mediated by at least two mechanisms of disease-increased hepatic glucose output manifested as fasting hyperglycemia and uncoupled postprandial insulin secretion manifested as postprandial hyperglycemia $[115,128]$ - a single blood test or measurement may not identify all or most of individuals affected by the disease [115]. Therefore, the actual prevalence of diabetes may still be underestimated in many countries, as highlighted in previous reviews $[5,15,124]$.

The etiologies of diabetes mellitus are complex. Thus, the increasing prevalence of diabetes experienced across LatAm may reflect the convergence or interaction of multiple factors $[18,125,129]$. For instance, the increasing prevalence of overweight and obesity documented across LatAm has paralleled the increasing prevalence of diabetes in the region $[84,125,130,131]$. In addition to increased adiposity, type 2 diabetes mellitus and insulin resistance have also been linked to malnutrition (at different life stages) in some LMICs [130, 132-134]. Stress associated with chronic poverty, intergenerational poverty, natural disasters, and other adverse events [1, 129, $132,135]$ has been linked to chronic systemic inflammation and epigenetic changes, potential common denominators of multiple NCDs [136, 137]. Many LatAm major cities may be epicenters where a fragile built environment and infrastructure and changes in lifestyle and nutrition intersect increasing the cumulative risk of developing diabetes in low-income communities [30, 126, 127, 129, $135,138,139]$. Increased life expectancy has been associated with increased diabetes prevalence $[4,16,30,125$, 140], whereas higher educational attainment, increased access to health care, and higher health literacy level are associated with increased awareness of the disease [117]. These are all factors to consider upon designing comprehensive diabetes prevention and treatment strategies across LatAm countries.

In addition, the growing prevalence of diabetes mellitus across LatAm and the complexity of the disease suggest opportunities to create or strengthen collaborations towards its prevention and early detection [141-144]. For example, multinational and multidisciplinary researchpublic health-health care policy-clinical care partnerships which already exist in formal or informal platforms may be well-positioned to evaluate the impact of nutrition, health insurance, housing, and other public policies [79, 141, 143, 145-154] on health outcomes and assess their potential translation into preventive strategies at the public health and clinical care levels. At the same time, the eventual implementation of such strategies will be strengthened by 
local governments' commitment to prioritize the prevention and treatment of NCDs, in this case, diabetes, as previously voiced by experts and advocates in the region [79, $141,155-158]$.

\section{Diabetes Awareness, Treatment, and Control}

\section{Diabetes Awareness}

Although fewer than studies focused on prevalence, a considerable number of reports centered on diabetes awareness, treatment, and control across LatAm were published between 2005 and 2020 (Table 2) [33, 37, 40, 41, 43, 44, $49,51,60-63,65,72,73,87,98,101,103,104,111,112$, 159-189]. A few of the studies evaluated diabetes awareness, treatment, and control altogether [85, 185, 189]. Most studies did not use the term "diabetes awareness," but equated it (or more appropriately, diabetes unawareness) to "suspected," "undiagnosed," "unknown," or "new" diabetes or "elevated glycemia."

"Undiagnosed" diabetes - a proxy for lack of diabetes awareness - ranged widely from 10.3 to $50 \%$ across studies and countries (Table 2). The prevalence of undiagnosed diabetes was higher in Guatemala (48.8\%), Uruguay (48.7\%), Puerto Rico (37.7-50\%), Honduras (31.9-53.7\% range), Mexico (29.9-50\% range), and Nicaragua (43.3\%) and lower in Colombia (Bogota) (23.5\%), the southernmost countries of South America (20.2\%), and Costa Rica (10.3-28.4\%). Irazola et al. [189] described that diabetes awareness slightly increased with educational attainment. However, associations between undiagnosed diabetes with age, sex, educational attainment, SES, or geographic location were not published by most studies.

The observed range of undiagnosed diabetes suggests that the actual prevalence of diabetes across LatAm could exceed previous estimates $[6,124]$ and that a potentially significant proportion of persons with diabetes for whom both macroand microvascular complications may be present but not assessed and treated. Therefore, current estimates of the prevalence of diabetes across continents may not fully account for the necessary resources to provide adequate health care for Latin Americans with diabetes [7, 8, 190, 191]. Considering the workforce and resources needed to screen the millions of persons across the region who are at risk of diabetes or have the disease and are not aware, experts have proposed diabetes predictive models requiring specific easily obtained clinical data points that could be readily used in primary care settings [192-194]. Also, the Finnish Diabetes Risk Score (FINDRISC) has been proposed, tested, or modified to screen and identify individuals at high risk of developing diabetes in Latin America [195-199]. Point-of-care tests for HbAlc and urine microalbumin have also been proposed as alternatives to identify persons with "undiagnosed diabetes" and/or those at risk of chronic kidney disease (CKD) in low-resource and remote settings in LatAm [200-203]. The standardization, reliability, and repeatability of some of these tests, as well as the clinical and public health benefit derived from their integration into the health care systems, may need to be determined [204]. However, these and other emerging diagnostic technologies $[205,206]$ are promising alternatives that could be incorporated to assess the prevalence of diabetes and implement timely interventions.

\section{Treatment and Control of Diabetes, Blood Pressure, and LDL-C}

The percent of persons with diabetes following any treatment for diabetes ranged from 52.6 to $99 \%$ across studies (Table 2). Prescription and/or use of antihyperglycemic medications was mostly assessed via interviews, although a few studies evaluated medical records. Most individuals reported taking oral antihyperglycemic medications either as monotherapy or as a combination of oral medications, while a smaller percent reported using insulin alone or in combination with oral medications. Five (5\%) to $12.9 \%$ only followed diet/exercise prescription $[161,163,167,176,179,186]$, and 3.2 to $10.1 \%$ were not taking any medications [41, 104, 168, 169, 175]. Receiving or adhering to pharmacological treatment was positively associated with having health insurance [71], and receiving medical care in private rather than public health care settings [71, 187]. At least one study observed better pharmacologic treatment adherence with female sex [185].

Achievement of ADA/ALAD-recommended glycemic goals $[23,207]$ was assessed by multiple studies. The percentage of persons attaining $\mathrm{HbAlc}<7 \%$ ranged from 3.5 to $54 \%$. However, some studies defined glycemic control based on fasting or random blood glucose thresholds and reported attainment of glycemic control in the 31.4 to $61.4 \%$ range. Attainment of glycemic control was associated with higher socioeconomic status (SES) [160], having health insurance [160], and better access and services [208]. Not attaining glycemic control was associated with longer duration of diabetes $[163,187,209]$, taking insulin (alone or in combination with oral antihyperglycemic medications) [176], forgetfulness (e.g., taking multiple medication for more than one condition) [185], complex therapeutic regimes [209], inadequate access to health care services [22], and availability or health insurance coverage of medications [187], among other factors.

In addition to glycemic control, a smaller number of studies examined the attainment of ADA/ALADrecommended blood pressure and LDL-C-blood pressure $<130 / 80 \mathrm{mmHg}$ and LDL-C $<100 \mathrm{mg} / \mathrm{dL}$ - for patients with diabetes [24, 207]. The percentage achieving blood pressure goals ranged from 25 to $67 \%$, and the percent achieving LDL-C goals ranged from 12 to $52.6 \%$ 


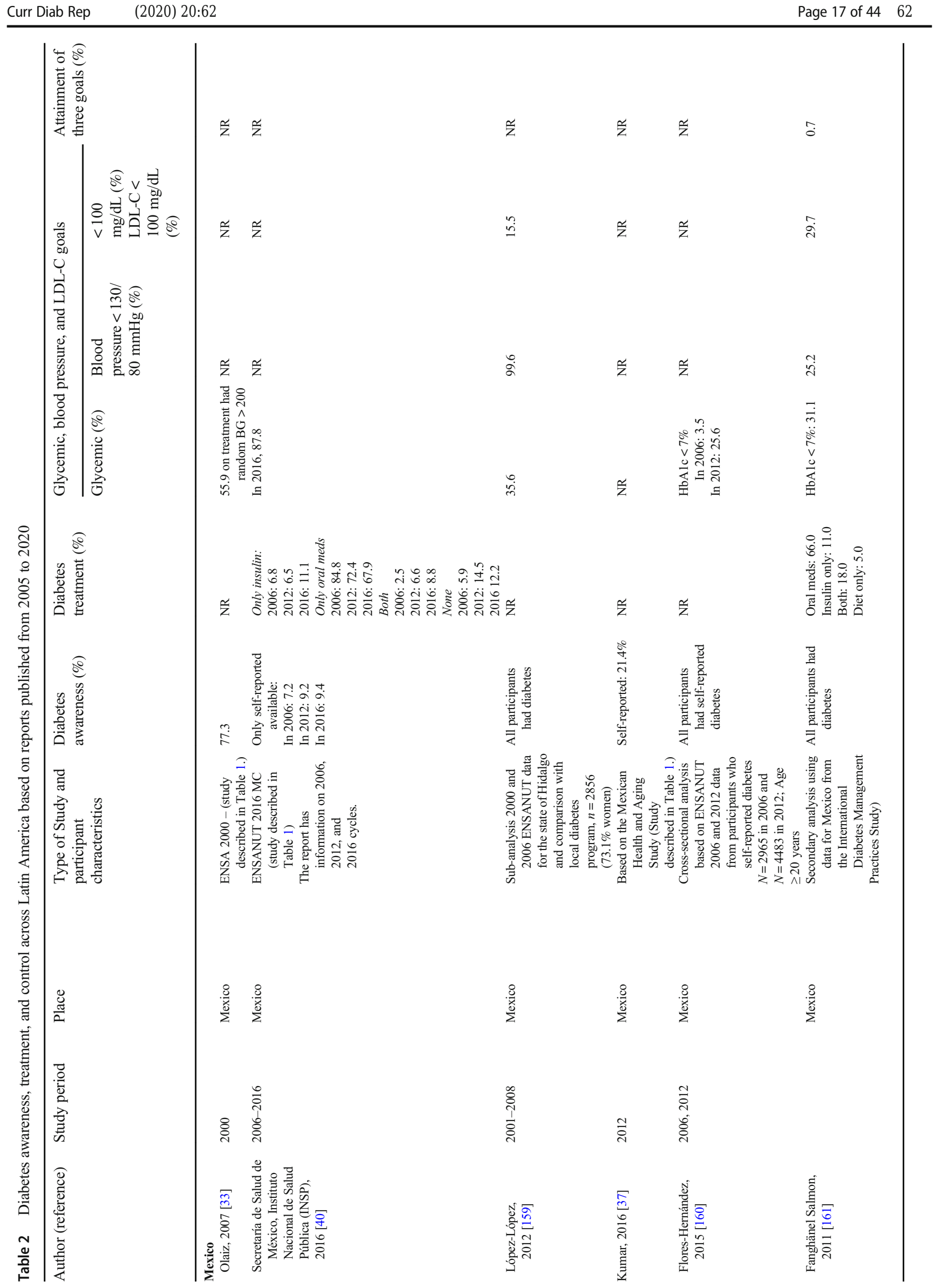




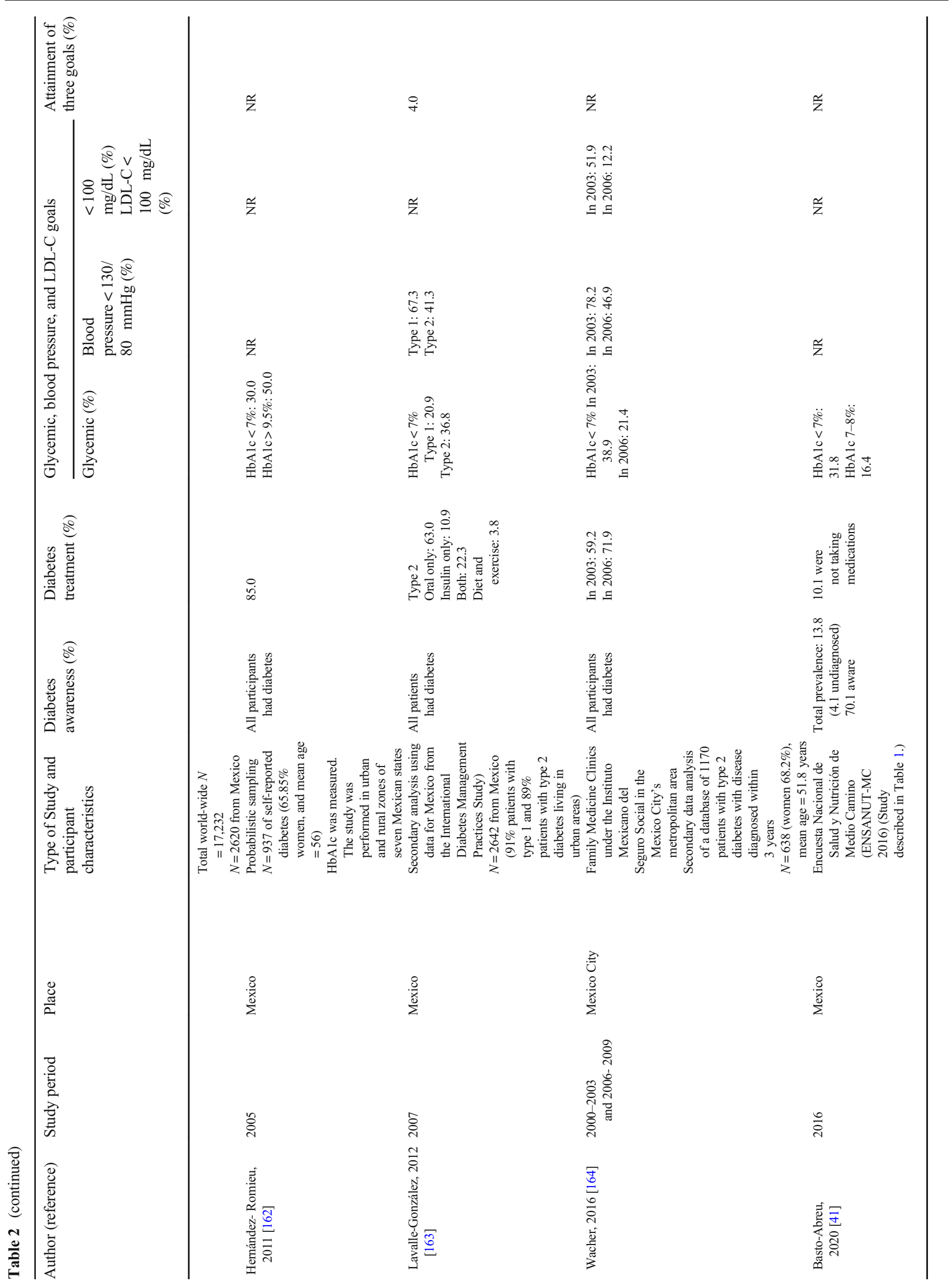




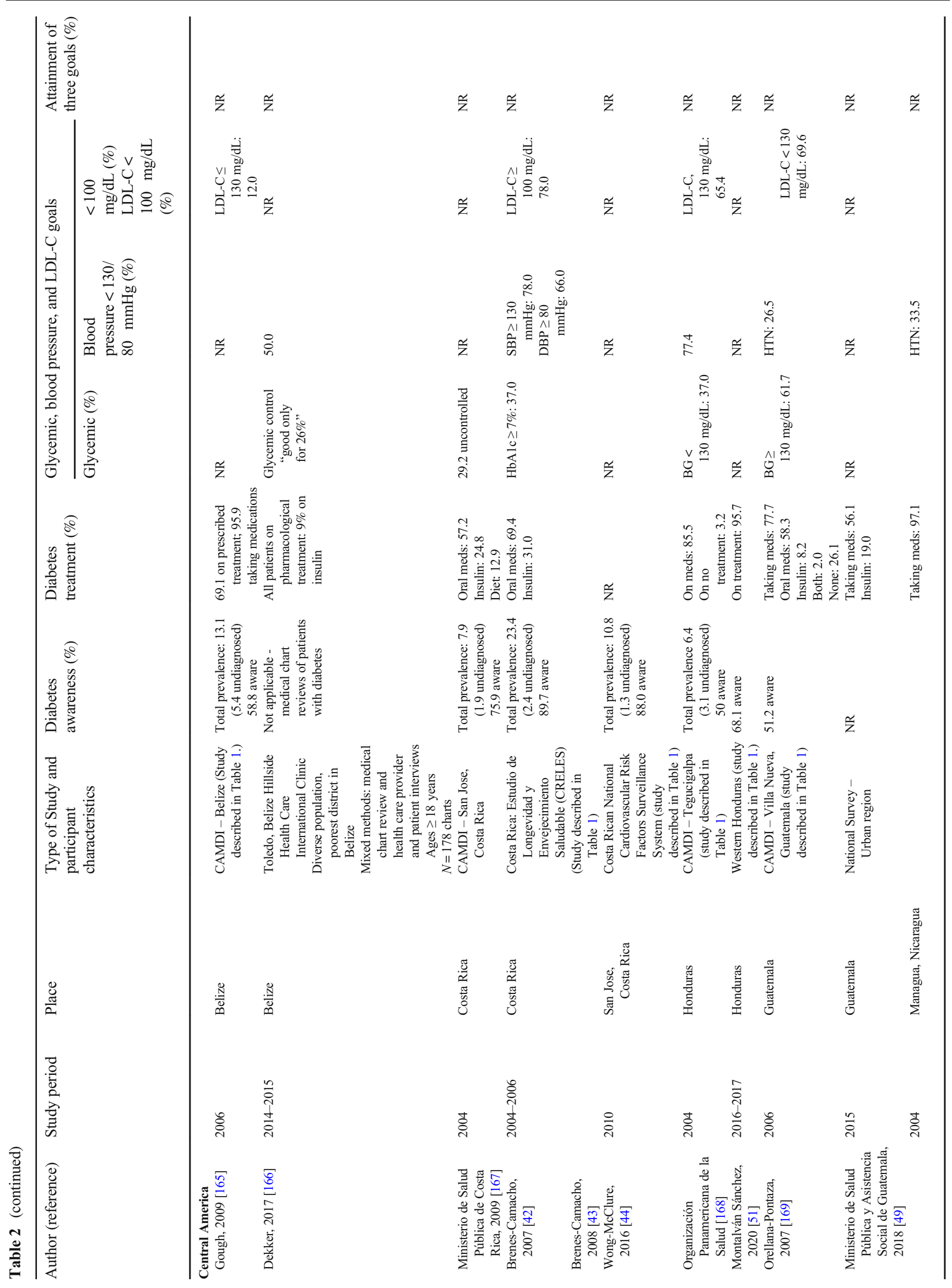




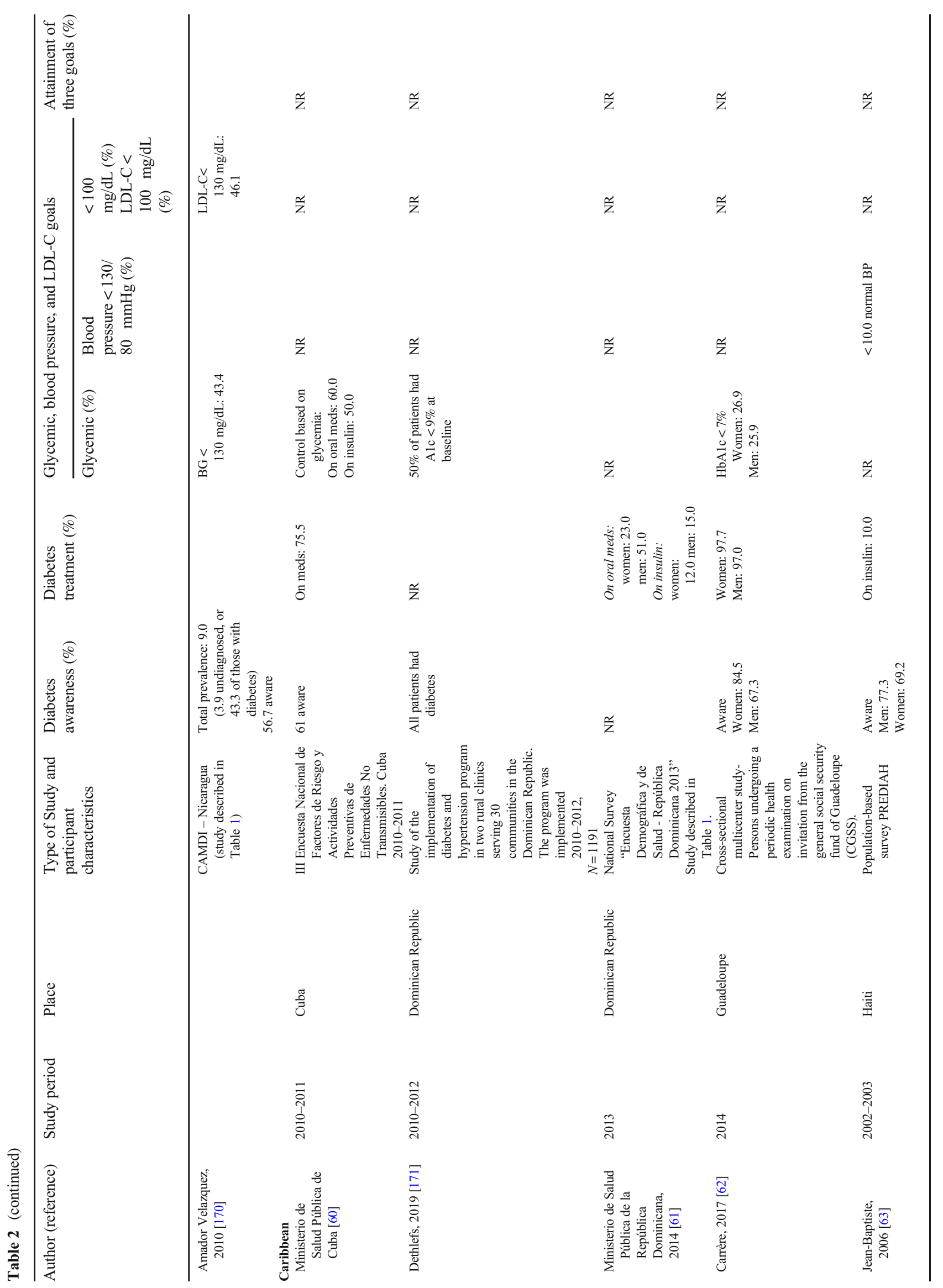




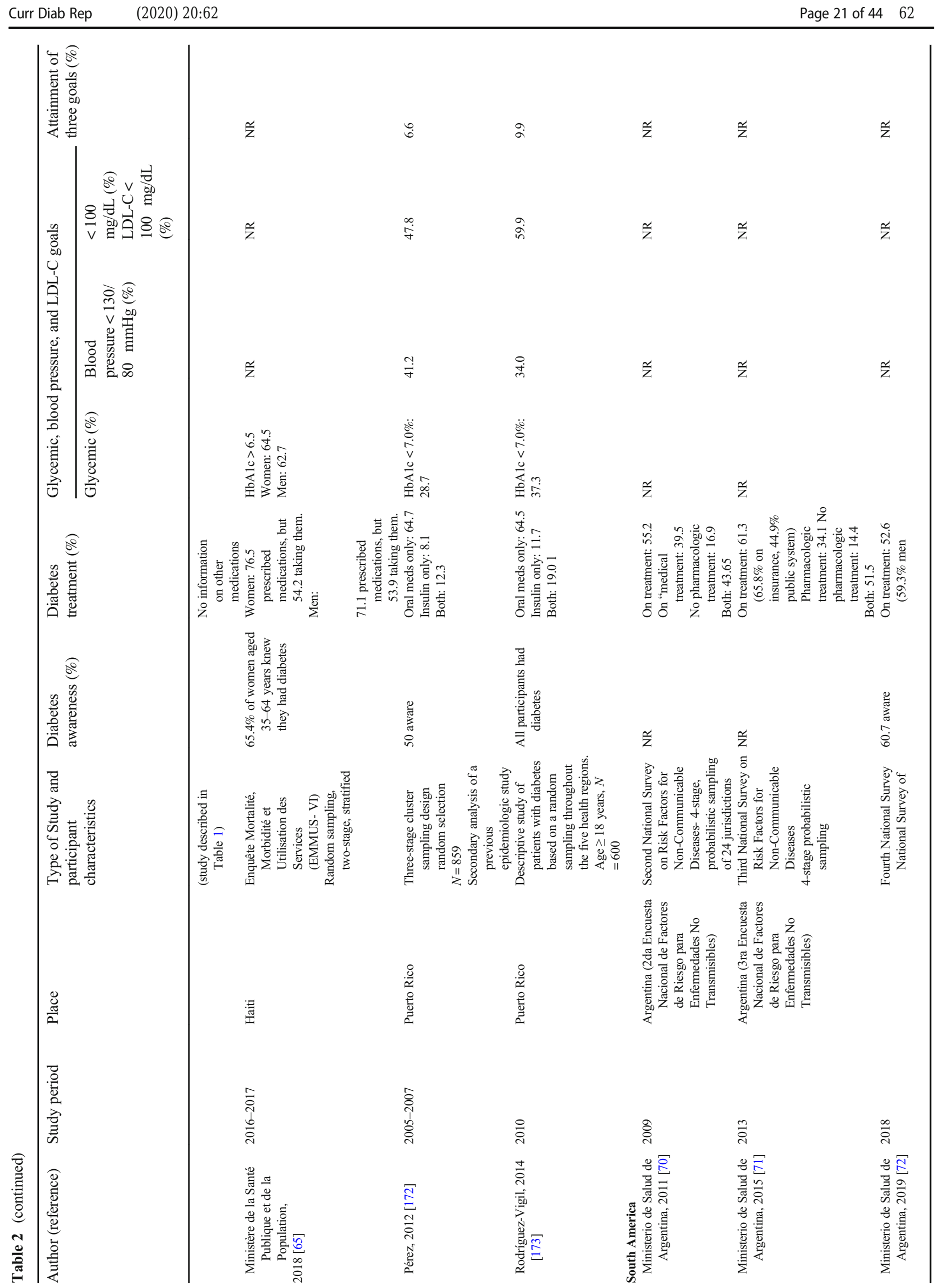




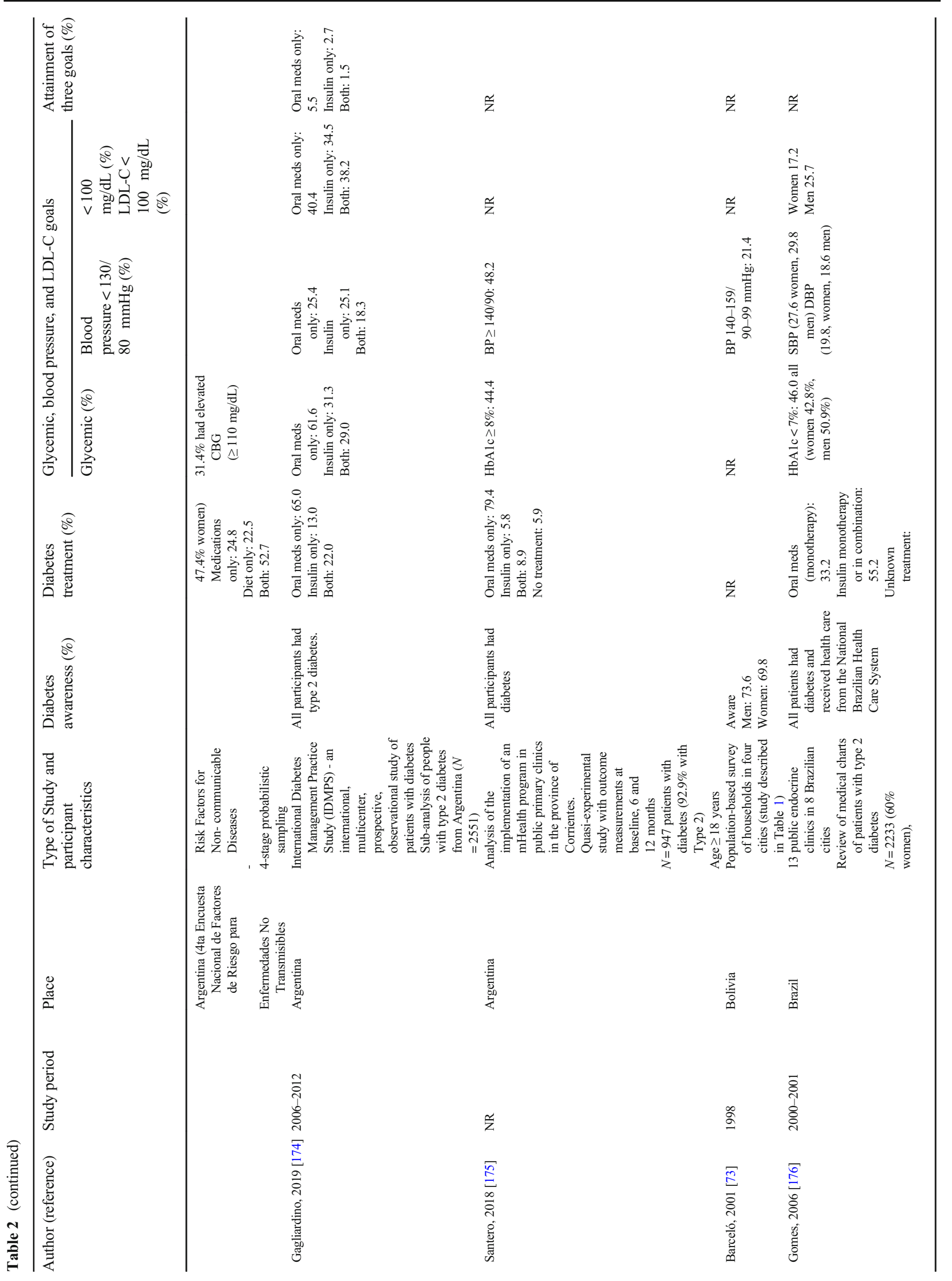




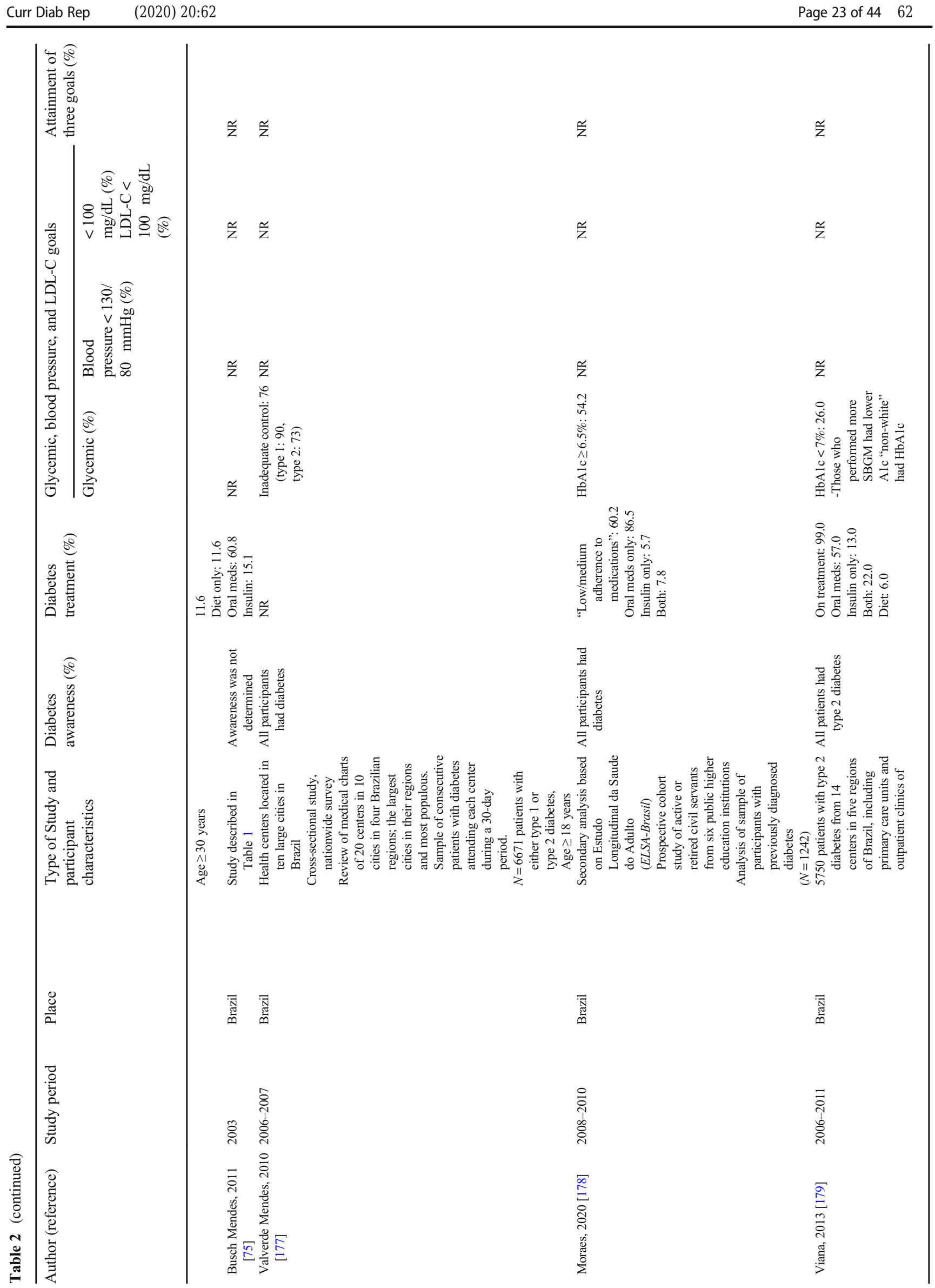




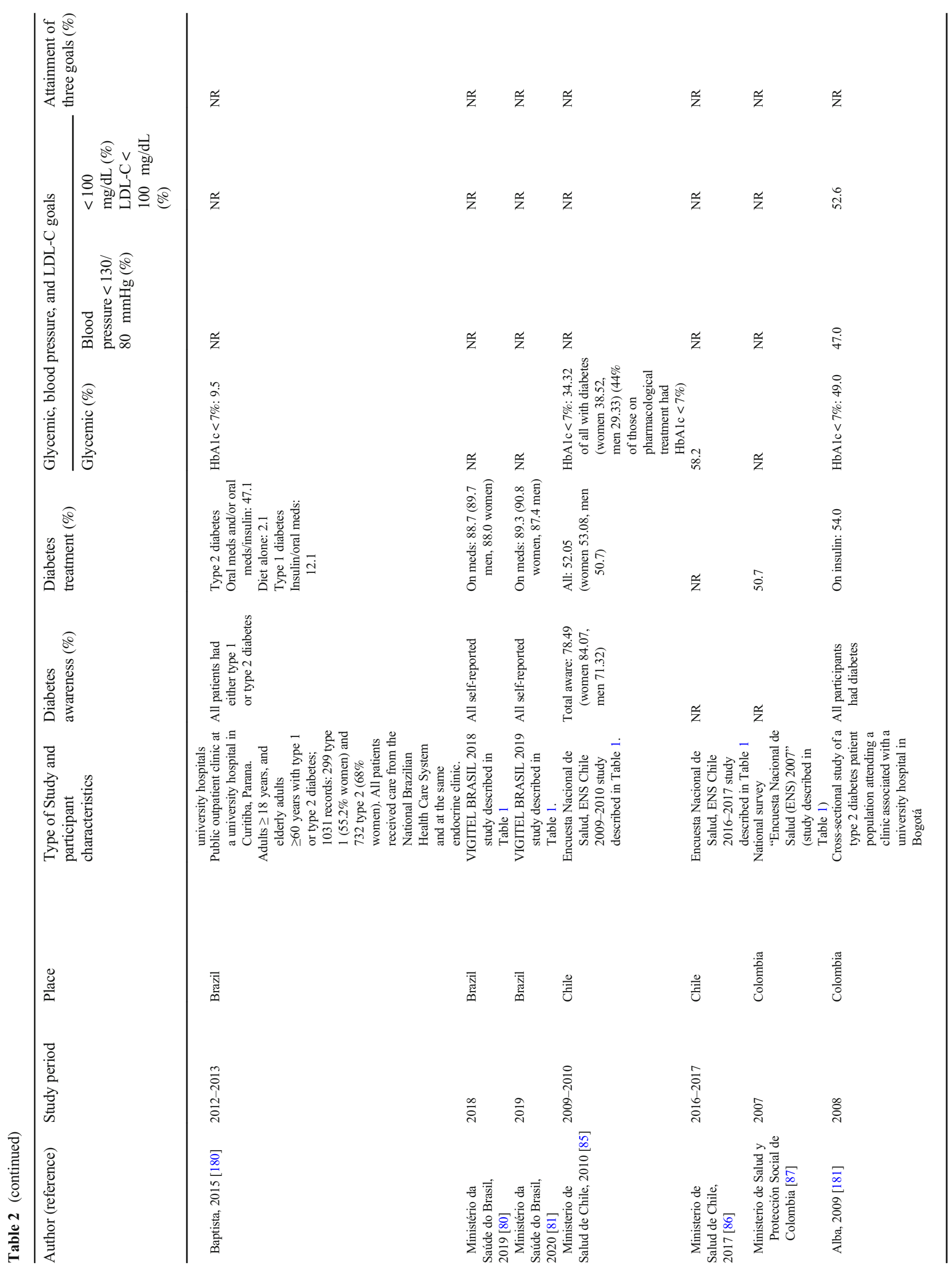




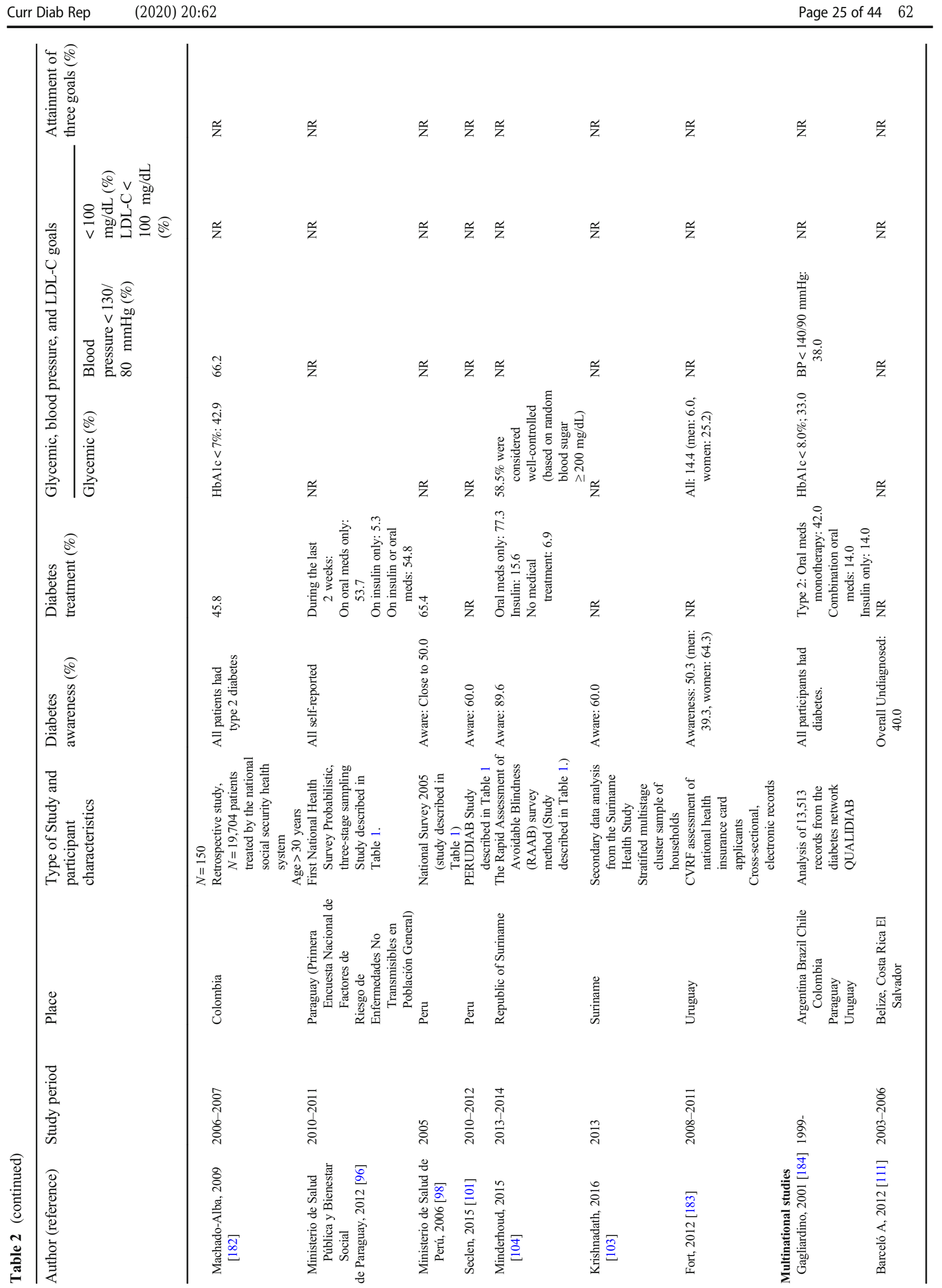




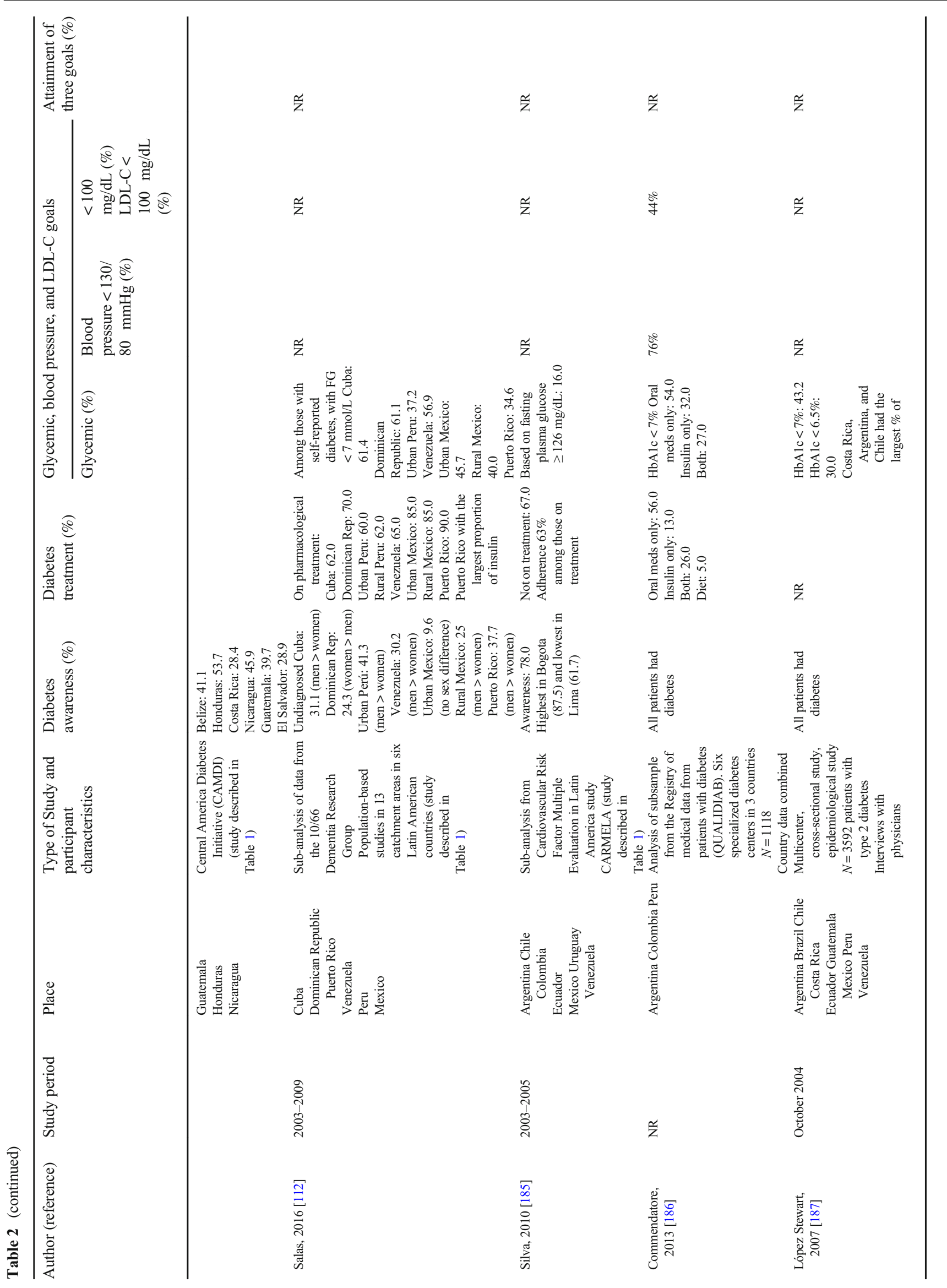




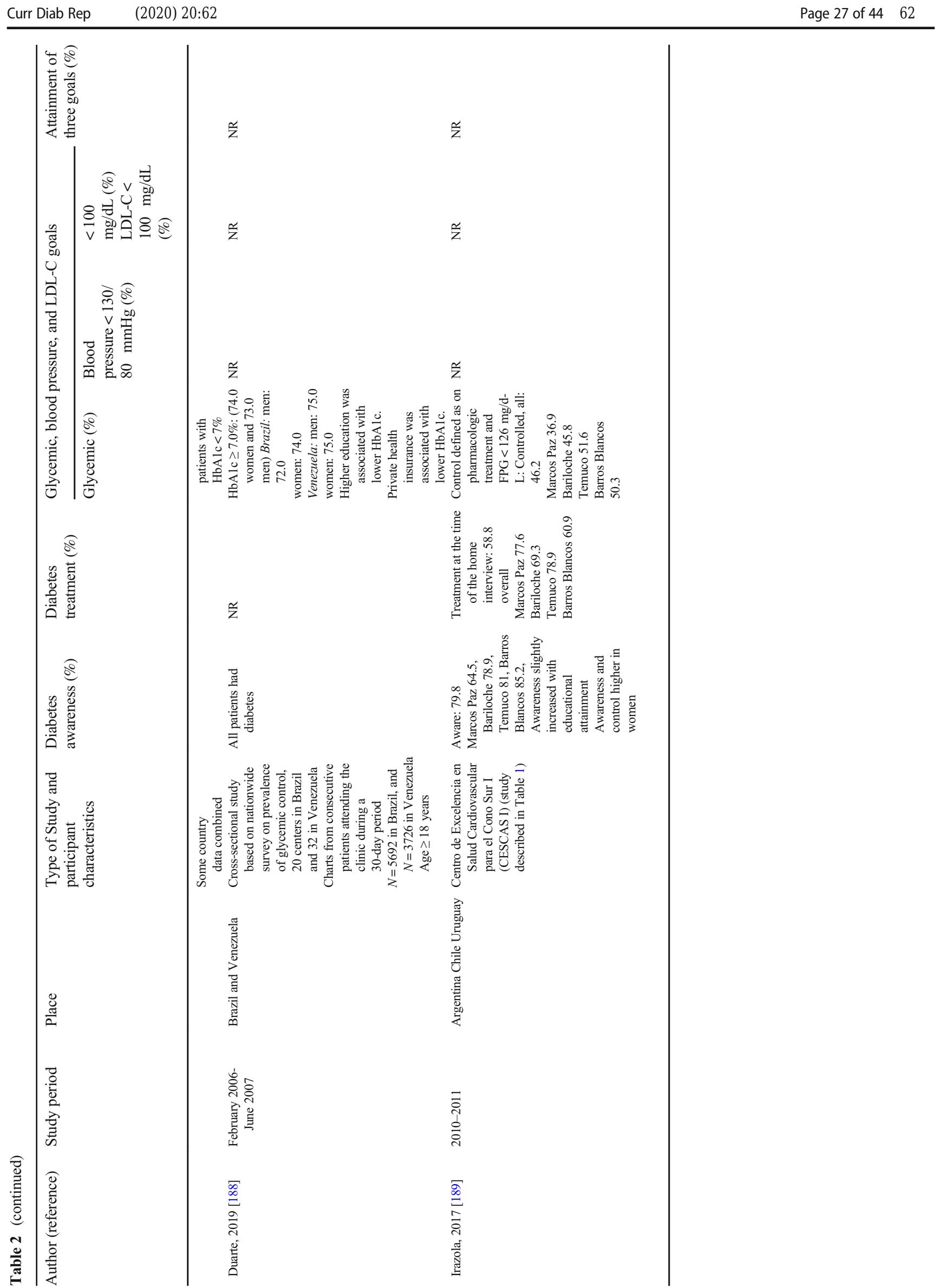


(Table 2). The percent achieving optimal glycemic, blood pressure, and LDL-C levels altogether was reported by a handful of studies and up to $9.9 \%$ (Table 2).

The findings described above denote critical aspects of the state of diabetes care in Latin America. The achievement of glycemic goals reported by the studies included in our review is similar to previously published studies $[164,179,180,187$, 210]. This implies seriously chronic and inadequate glycemic control at the population level across the region.

The inclusion of questions on treatment for glycemic control, medical, and self-care in some national surveys increases our understanding of health-seeking behaviors, both patients' and clinicians' adherence to recommended guidelines of care, and challenges related to the utilization of health care services and availability of medications. The smaller number of studies reporting on the attainment of blood pressure and LDL-C goals and the proportion of patients achieving those goals also poses questions about the prevention of macrovascular complications in persons with diabetes in Latin America, considering the raising prevalence of CVD in the region $[16,211]$. Of note, most national surveys report prevalence and treatment and/or control of diabetes, hypertension, and blood cholesterol and the prevalence of tobacco use individually. Since diabetes involves multiple organs and deserves a holistic care approach, reporting on the co-existence of other $\mathrm{CV}$ risk factors with diabetes would enhance critical understanding of $\mathrm{CV}$ risk and health care needs. Also, some surveys collected biospecimens, but the test results were not included in the reports. It is possible that they are analyzed and published later. Yet including test results in the surveys would offer a more comprehensive picture of the status of diabetes prevention and care needs $[180,212,213]$ to plan interventions accordingly.

\section{Following Guidelines of Care for the Prevention of Microvascular Disease}

Various studies included in our review reported on participants' receiving or following ADA/ALAD-recommended guidelines of care [25] for early detection and prevention of microvascular disease - annual fundoscopic exam, examination for peripheral neuropathy and comprehensive foot examination, annual function/urine albumin excretion testing, and $\mathrm{HbA} 1 \mathrm{c}$ tested at least 3 times per years [38-40, 72, 96, 159, $160,165,166,168,169,171,172,175,176,180,182,186$, 214] (Table 3). Some studies assessed the completion of several guidelines, whereas most studies focused on a few. The completion of the selected ADA guidelines varied, ranging from 14.7 to $97.5 \%$ for the foot exam, from 8.6 to $92 \%$ for the fundoscopic exam, and from 1.1 to $51.1 \%$ for the urine albumin excretion test. Most studies (especially national surveys) inquired about having $\mathrm{HbAlc}$ checked within the previous 12 months. The affirmative response ranged from 3.7 to
90.0\%. In addition to inquiring about $\mathrm{HbAlc}$ testing, some surveys asked whether the participant's blood glucose had been tested (by a health care professional). Having private health insurance was associated with a greater number of affirmative responses to the latter [70, 71, 91].

Despite the smaller number of studies evaluating the completion of the ADA guidelines for foot care and prevention of microvascular disease, and the varied guideline completion rates previously described (Table 3), the prevalence of long-term microvascular complications associated with diabetes has been documented across LatAm. For instance, in the studies included on our review and others published during the same time frame, the rate of foot ulcers ranged from 1.2 to $14.8 \%$ [40, 214-216], and nontraumatic lower extremity amputations attributable to diabetes ranges from 1.2 to $7.3 \%$ [40, 184, 214, 215, 217-221], and the prevalence of diabetic retinopathy ranged from 11.2 to $48 \%$ [40, 184, 214, 222, 223]. CKD has become a major public health concern across Central America [224-226], and the increasing prevalence of diabetes could exacerbate the incidence of CKD - and eventually end-stage renal disease and its associated health complications - in the region [227-229].

\section{Innovative Solutions: Emerging Research and Alternative Models of Care}

The findings described above underline not just the urgent need to prevent diabetes but also to prevent complications among those with established disease, and the potentially underestimated burden on patients, societies, and health care systems across LatAm. In this regard, several innovative models of health care for patients with diabetes have been proposed and tested throughout LatAm. Combining care of diabetes and other chronic conditions would be expected to maximize time and resources and improve health outcome. Although combining diabetes and chronic pulmonary disease care did not demonstrate a difference in outcomes [230], this model could be revisited. Also, interventions at the health care system element of the chronic care model might need to be adapted to the local health care system [231] or synchronized with interventions at other levels. Improvement of health care system structure and processes [232] would assure timely access to patient information and enhance clinician decisionmaking. Integrating social determinants of health into diabetes care demonstrated objective improvements in patient knowledge and cardiometabolic parameters [233]. Enhancing medical continuing education [234], an intervention combining diabetes prevention and self-management [235], co-creating interventions with community stakeholders and other countries $[141,144]$ are other examples of alternatives to improve diabetes care throughout the region. Another major regional example of efforts to implement better care for patients with 





diabetes has been led by the Latin American Diabetes Association (ALAD in Spanish) to engage 17 medical associations and wrote a consensus statement on the treatment of type 2 diabetes in LatAm [207].

Kaselitz et al. published a scoping review of policies and interventions for diabetes in LatAm [147], telehealth, mobile clinics, and other non-traditional health care delivery models. In addition, a non-exhaustive list of examples of past or current interventions, policies, and initiatives is provided in Table 4 [184, 186, 234, 236-252]. Interventions in the list include tele-ophthalmology [249, 250, 253, 254], teambased foot self-care education [236], diabetic retinopathy education and screening at a community pharmacy [255], rapid assessment/diagnostic tools to screen for or detect retinopathy, nephropathy, and risk of developing foot ulcers [201, 256-262] and are examples of clinical research and/or implementation activities designed to strengthen the prevention and early detection of diabetes-associated complications and improve health outcomes throughout LatAm.

Many interventions on diabetes care have focused on patients and/or clinicians as the primary recipients or enablers of the interventions. Because of the complex nature of the disease and the multiple factors that mediate treatment effectiveness, interventions involving other levels or elements within the health care organization or system $[155,157,232$, 263-265] or the health care workforce [158, 263, 266] could be considered. Interventions involving other sectors (e.g., housing, infrastructure, national or local policies) could uncover very valuable and needed strategies to enhance treatment effectiveness and potentially reduce health care costs in the long-term. The feasibility and sustainability of such research efforts - and subsequent policies - would need to be demonstrated and supported locally [143].

\section{Additional Observations}

\section{Women}

Multiple studies in our review reported a higher prevalence of diabetes among women $[36,38,40,42,44,47,49-52,57,60$, $62,63,65,70,72,75,78,79,83-86,90,95,96,110,113]$. While the mediating factors for this sex difference need further study (e.g., history of GDM, which was outside of the scope of this review), the increased prevalence of diabetes among women in some LatAm countries would be expected to have implications for health and health care, and potentially future generations [267-269]. Since diabetes may increase women's risk for CVD, including stroke [270], cognitive decline [271, 272], or some cancers [273, 274], timely and comprehensive preventive care for women of all ages would need to be prioritized.

\section{Older Adults}

Due to the epidemiologic transition already experienced by some countries throughout LatAm, the population pyramid is also shifting towards a greater proportion of older adults. Studies included in our review consistently reported an increased prevalence of diabetes with age. Diabetes care challenges specific to this age group include risk of obesity or undernutrition $[42,56]$, increased risk for disability [57], economic barriers to appropriate access to health care [42], disruption in funding of health insurance [275], disparate completion of diabetes care guidelines based on health insurance coverage [276], inequalities in access to and utilization of health care services [277-279], complex medical care needs and frailty [280], cultural beliefs, mental health, and lack of family or social support [281], among others. Prevention of diabetes and its complications and reliable continuity of care and social support [282] need to be especially tailored for this population across the region.

\section{Indigenous and Other Ethnic Underserved Populations}

A few studies in our review reported a low prevalence of diabetes among some indigenous populations in LatAm $[55,74,82]$, in parallel to some previous reports [283-286] about other indigenous groups in the region and in contrast with the higher prevalence of diabetes among American Indians in the USA [287] and the First Nations in Canada [288]. However, other studies in our review and in the current literature have documented elevated diabetes prevalence or risk among indigenous and other socioeconomically disadvantaged ethnic groups [48, $50,73,76,77,83,90,91,166,289-293]$. Some of the diabetes prevalence studies included in our review focused on or mentioned participants from indigenous groups [35, $48,50,74,83]$ and other underrepresented groups (e.g., Garifuna, Afro-Panamanian, Afro-Peruvian, AfroEcuadorian) $[55,76,90,91,166]$. However, a few studies have evaluated diabetes care, prevalence, and/or prevention of macro- or microvascular complications, diabetes management interventions, other health care needs and access to health care among indigenous populations [241, 244, 246, 294-302], and none on the other groups (that we could identify through our search). Understanding the protective mechanisms (e.g., biochemical, immune, epigenetic) against diabetes experienced by some indigenous populations would be relevant to millions at high risk of developing diabetes. At the same time, the increased prevalence of the metabolic syndrome and diabetes experienced by some indigenous groups and other ethnic groups may increase their risk not only for CVD and other diabetes long-term complications but also for re-emerging 
Table 4 examples of past and ongoing diabetes care interventions initiated in Latin America from 2000 to 2020

\begin{tabular}{lll}
\hline Author [reference] & Year of Study & Place \\
\hline Batista, 2010 [236] & $2000-2010$ & São Paulo, Brazil \\
Barceló, 2010 [237] & $2002-2004$ & Mexico \\
Lerario, 2010 [238] & & \\
Piette, 2013 [239] & 2009 & Brazil \\
\hline
\end{tabular}

Piette, $2011[240]$

Piette, 2016 [241]

Piette, 2014 [242]

Prestes, 2017 [243]

Flood, 2016 [244]

Flood, 2017 [245]

Flood, 2017 [246]

Tapia-Conyer, 2016 [247]

Gallardo-Rincón, 2017 [234]
$2013 \quad$ Bolivia

2013

Bolivia

2016-2017 Argentina

Guatemala

2012

2014-2016

Rural Guatemala

2012 to present Mexico
Key findings

A multidisciplinary health care team was established aiming at increasing limb salvage

The VIDA project - RCT to test improvement of quality of diabetes care in primary health care centers using the chronic care model and the breakthrough series collaborative methodology. The proportion of patients attending the clinics under the intervention with $\mathrm{HbA} 1 \mathrm{c}$ $<7 \%$ increased from $28 \%$ to $39 \%$, and the proportion of patients who achieved 3 or more quality improvement goals increased from $16.6 \%$ to $69.7 \%$.

The Brazilian Diabetes Society developed a new algorithm for the treatment of type 2 diabetes

Interactive Voice Response (IVR) support calls for chronic disease management for Spanish speakers- The investigators report cumulative findings in Honduras, Mexico, and Spanish-speakers in the U.S. Involvement of caregivers enhanced engagement. By self-report, there was improved medication adherence and self-management was similar across sites.

Cloud-Computing Model - The investigators tested a mobile phone-based intervention of weekly VoIP calls and IVR with patients with diabetes and automated emails to clinicians and voicemail reports to family caregivers for six weeks. Improved self-care and diabetes management and significant improvement in glycemic control were reported.

Structured caregiver feedback - The investigators assessed whether automated telephone feedback to caregivers ("CarePartners") increased engagement in mobile-health support among patients with diabetes and hypertension in Bolivia. Significantly greater engagement was observed. Patients who spoke indigenous languages at home were more than $3 \mathrm{X}$ as likely to complete the IVR calls.

Mobile health program for chronic disease self-management in Bolivia - Assessment and implementation of IVR for 12 weeks. It was associated with improved medication adherence, self-reported health status, and satisfaction.

DIAPREM - integrated diabetes care program including systemic changes education, registry and disease management

Implementation and outcomes of a comprehensive type 2 diabetes program in rural Guatemala through a non-government organization and involving nurse-directed care

Implementation of a multi-level quality improvement program for ambulatory diabetes care based on input from patients and other stakeholders

Home-based type 2 diabetes self-management intervention delivered by diabetes educator at home and synchronized with clinic follow-up. Mayan communities

CASALUD Model -is a comprehensive primary health care model implemented in Mexico that enables proactive prevention and disease management using innovative technologies and a patient-centered approach. The program was pilot tested in 2009 and implemented nationwide in 2012. 
Table 4 (continued)

\begin{tabular}{|c|c|c|c|}
\hline Author [reference] & Year of Study & Place & Key findings \\
\hline Salamanca, 2018 [248] & $2014-2017$ & Peru & $\begin{array}{l}\text { Implementation of a diabetic retinopathy referral and } \\
\text { treatment network via collaboration and co-funding } \\
\text { from a non-governmental organization. }\end{array}$ \\
\hline Avendaño-Veloso, 2019 [249] & $2014-2015$ & Chile & $\begin{array}{l}\text { A non-experimental teleophthalmology program in the } \\
\text { public health system to increase the reach of patients at } \\
\text { risk of having diabetic retinopathy. The program } \\
\text { allowed the evaluation of more than a quarter of the } \\
\text { patients with diabetes. }\end{array}$ \\
\hline Flores, 2019 [250] & 2016 & Chile & $\begin{array}{l}\text { Implementation of a telemedicine model management } \\
\text { network for diabetic retinopathy at a primary care level. }\end{array}$ \\
\hline Cani, 2015 [251] & Not mentioned & Brazil & $\begin{array}{l}\text { RCT to an intervention individualized } \\
\text { pharmacotherapeutic care and diabetes education by a } \\
\text { pharmacist. At } 6 \text { months the HbAlc improved } \\
\text { and quality of life }\end{array}$ \\
\hline $\begin{array}{l}\text { Gagliardino, } 2013[252] \\
\text { Gagliardino, } 2001[184] \\
\text { Commendatore, } 2013[186]\end{array}$ & 2007-2009 & $\begin{array}{l}\text { Argentina } \\
\text { Argentina and other countries }\end{array}$ & $\begin{array}{l}\text { PRODIACOR prospective intervention of diabetes } \\
\text { education in primary care settings in the } \\
\text { city of Corrientes } \\
\text { QUALIDIAB Network- Registry of type } 2 \text { diabetes } \\
\text { patients to measure the quality of care }\end{array}$ \\
\hline
\end{tabular}

infectious diseases, like tuberculosis [303-305]. Therefore, disease prevention and health care models that account and reach these populations need to be considered.

\section{Conclusion}

Through this review, we have highlighted the most current reports on prevalence, awareness, treatment, control, and adherence to recommended guidelines of care for diabetes mellitus across LatAm published from 2000 to 2020. During that time frame, a considerable number of surveys assessing the prevalence of the disease and an increasing body of reports on the achievement of treatment and care goals were identified. Such reports demonstrate the imperative need to garner a more comprehensive understanding of the extent of diabetes across countries, and both past and ongoing efforts to establish effective and sustainable models of prevention and high-quality care able to reach and serve all peoples across the region.

During the writing of this manuscript, Latin America had been recognized as the new epicenter of the SARS-CoV-2 (COVID-19) pandemic [306]. The effects of the disease in persons with diabetes in the region are beginning to be uncovered [307-309], while some solutions are proposed [310, 311]. The magnitude of the impact of the pandemic on the health and health care needs of persons with diabetes mellitus and other NCDs - let alone on the health care systems infrastructures - in the region are yet to be known. The task ahead is substantial and will require multidisciplinary and cross-sectoral strategies and collaborations to reduce diabetes burden and improve health outcomes across Latin America.

Acknowledgments The authors would like to thank Ms. Jill Pope (Kaiser Permanente Center for Health Research) for her valuable review of the manuscript and the Ponce Health Sciences University for creating the opportunity for AM-R and AS-S to work in this review.

Authors' Contributions MLAS conceptualized the review. MLAS and NML co-led the literature search and the discussion of findings. AMR and ASS performed part of the literature search, summarized and discussed findings, and contributed to the writing. MLAS performed part of the literature search and wrote the manuscript. NML provided critical review to the manuscript. All authors approved the final version of the manuscript.

\section{Data Availability NA}

\section{Compliance with Ethical Standards}

Conflict of Interest The authors declare that they have no conflict of interest.

Disclaimer The views expressed in this manuscript are those of the authors and do not necessarily reflect the official views of the National Institute on Minority Health and Health Disparities, the National Institutes of Health, or the U.S. federal government.

Code Availability NA

\section{References}

1. Bukhman G, Bavuma C, Gishoma C, Gupta N, Kwan GF, Laing $\mathrm{R}$, et al. Endemic diabetes in the world's poorest people. Lancet 
Diabetes Endocrinol. 2015;3(6):402-3. https://doi.org/10.1016/ s2213-8587(15)00138-2.

2. Miranda JJ, Barrientos-Gutiérrez T, Corvalan C, Hyder AA, LazoPorras M, Oni T, et al. Understanding the rise of cardiometabolic diseases in low- and middle-income countries. Nat Med. 2019;25(11):1667-79. https://doi.org/10.1038/s41591-019-0644-7.

3. King H, Aubert RE, Herman WH. Global burden of diabetes, 1995-2025: prevalence, numerical estimates, and projections. Diabetes Care. 1998;21(9):1414-31. https://doi.org/10.2337/ diacare.21.9.1414.

4. Danaei G, Finucane MM, Lu Y, Singh GM, Cowan MJ, Paciorek $\mathrm{CJ}$, et al. National, regional, and global trends in fasting plasma glucose and diabetes prevalence since 1980: systematic analysis of health examination surveys and epidemiological studies with 370 country-years and 2.7 million participants. Lancet. 2011;378(9785):31-40. https://doi.org/10.1016/s0140-6736(11) 60679-x.

5. Aschner P, Aguilar-Salinas C, Aguirre L, Franco L, Gagliardino JJ, de Lapertosa SG, et al. Diabetes in South and Central America: an update. Diabetes Res Clin Pract. 2014;103(2):238-43. https:// doi.org/10.1016/j.diabres.2013.11.010.

6. Saeedi P, Petersohn I, Salpea P, Malanda B, Karuranga S, Unwin $\mathrm{N}$, et al. Global and regional diabetes prevalence estimates for 2019 and projections for 2030 and 2045: Results from the International Diabetes Federation Diabetes Atlas, 9(th) edition. Diabetes Res Clin Pract. 2019;157:107843. https://doi.org/10. 1016/j.diabres.2019.107843.

7. Arredondo A. Type 2 diabetes and health care costs in Latin America: exploring the need for greater preventive medicine. BMC Med. 2014;12:136. https://doi.org/10.1186/s12916-0140136-z.

8. Barcelo A, Arredondo A, Gordillo-Tobar A, Segovia J, Qiang A. The cost of diabetes in Latin America and the Caribbean in 2015: evidence for decision and policy makers. J Glob Health. 2017;7(2):020410. https://doi.org/10.7189/jogh.07.020410.

9. Colón-Ramos U, Rodríguez-Ayuso I, Gebrekristos HT, Roess A, Pérez CM, Simonsen L. Transnational mortality comparisons between archipelago and mainland Puerto Ricans. J Immigr Minor Health. 2017;19(5):1009-17. https://doi.org/10.1007/s10903016-0448-5.

10. Alegre-Díaz J, Herrington W, López-Cervantes M, Gnatiuc L, Ramirez R, Hill M, et al. Diabetes and cause-specific mortality in Mexico City. N Engl J Med. 2016;375(20):1961-71. https:// doi.org/10.1056/NEJMoa1605368.

11. Bracco PA, Gregg EW, Rolka DB, Schmidt MI, Barreto SM, Lotufo PA, et al. A nationwide analysis of the excess death attributable to diabetes in Brazil. J Glob Health. 2020;10(1):010401. https://doi.org/10.7189/jogh.10.010401.

12. Carrillo-Larco RM, Barengo NC, Albitres-Flores L, BernabeOrtiz A. The risk of mortality among people with type 2 diabetes in Latin America: a systematic review and meta-analysis of population-based cohort studies. Diabetes Metab Res Rev. 2019;35(4):e3139. https://doi.org/10.1002/dmrr.3139.

13. Agudelo-Botero M, Dávila-Cervantes CA. Burden of mortality due to diabetes mellitus in Latin America 2000-2011: the case of Argentina, Chile, Colombia, and Mexico. Gac Sanit. 2015. https://doi.org/10.1016/j.gaceta.2015.01.015.

14. Panamerican Health Organization. Mortality in the Americas (https://www.paho.org/salud-en-las-americas-2017/?tag= cardiovascular-diseases). Pan American Health Organization, Washington, D.C. 2017. [Last Accessed on August 6, 2020].

15. Aschner P. Diabetes trends in Latin America. Diabetes Metab Res Rev. 2002;18(Suppl 3):S27-31. https://doi.org/10.1002/dmrr.280.

16. Fernando L, Pamela S, Alejandra L. Cardiovascular disease in Latin America: the growing epidemic. Prog Cardiovasc Dis. 2014;57(3):262-7. https://doi.org/10.1016/j.pcad.2014.07.007.
17. Conomos MP, Laurie CA, Stilp AM, Gogarten SM, McHugh CP, Nelson SC, et al. Genetic diversity and association studies in US Hispanic/Latino populations: qpplications in the Hispanic Community Health Study/Study of Latinos. Am J Hum Genet. 2016;98(1):165-84. https://doi.org/10.1016/j.ajhg.2015.12.001.

18. Avilés-Santa ML, Colón-Ramos U, Lindberg NM, Mattei J, Pasquel FJ, Pérez CM. From Sea to Shining Sea and the Great Plains to Patagonia: A Review on Current Knowledge of Diabetes Mellitus in Hispanics/Latinos in the US and Latin America. Front Endocrinol (Lausanne). 2017;8:298. https://doi.org/10.3389/ fendo.2017.00298.

19. Rodriguez-Castelan C, Lopez-Calva LF, Lustig N, Valderrama D. Understanding the dynamics of labor income inequality in Latin America (http://repec.tulane.edu/RePEc/pdf/tul1608.pdf). Tulane Economics Working Paper Series 2016. Accessed 4 August 2020 and 5 October 2020

20. Abramo L, Cecchini S, Ullmann H. Addressing health inequalities in Latin America: the role of social protection. Cien Saude Colet. 2020;25(5):1587-98. https://doi.org/10.1590/141381232020255.32802019 .

21. Greene J, Guanais F. An examination of socioeconomic equity in health experiences in six Latin American and Caribbean countries. Rev Panam Salud Publica. 2018;42:e127. https://doi.org/10. 26633/rpsp.2018.127.

22. Houghton N, Bascolo E, Del Riego A. Socioeconomic inequalities in access barriers to seeking health services in four Latin American countries. Rev Panam Salud Publica. 2020;44:e11. https://doi.org/ 10.26633/rpsp.2020.11.

23. American Diabetes Association. 6. Glycemic targets: $<\mathrm{em}>$ Standards of medical care in diabetes $-2020</ \mathrm{em}>$. Diabetes Care. 2020;43(Supplement 1):S66-S76. https://doi.org/ $10.2337 / \mathrm{dc} 20-\mathrm{S} 006$.

24. American Diabetes Association. 10. Cardiovascular disease and risk management: $<\mathrm{em}>$ Standards of Medical Care in Diabetes 2020</em>. Diabetes Care. 2020;43(Supplement 1):S111-S34. https://doi.org/10.2337/dc20-S010.

25. American Diabetes Association. 11. Microvascular complications and foot care: <em>Standards of Medical Care in Diabetes -2020</em>. Diabetes Care. 2020;43(Supplement 1):S135-S51. https://doi.org/10.2337/dc20-S011.

26. Asociación Latino Americana de Diabetes (ALAD). Guias ALAD sobre Diagnostico, Control y Tratamiento de la Diabetes Mellitus Tipo 2 con Medicina Basada en Evidencia, Edicion 2019 (www.revistaalad.com). Revista de la Asociacion Latinomericana de Diabetes (ALAD). 2019.

27. Paniagua M, Vizcarrondo R. Diabetes mellitus in Puerto Rico; statistical survey of 700 cases. Diabetes. 1952;1(5):373-7. https://doi.org/10.2337/diab.1.5.373.

28. West KM, Kalbfleisch JM. Glucose tolerance, nutrition, and diabetes in Uruguay, Venezuela, Malaya, and East Pakistan. Diabetes. 1966;15(1):9-18. https://doi.org/10.2337/diab.15.1.9.

29. Neri R. Panorama of chronic disorders in the República Oriental de Uruguay. Salud Publica Mex. 1967;9(5):687-707.

30. Omran AR. The epidemiologic transition. A theory of the epidemiology of population change. Milbank Mem Fund Q. 1971;49(4):509-38.

31. Frenk J, Lozano R, Bobadilla JL. The epidemiological transition in Latin America. Notas Poblacion. 1994;22(60):79-101.

32. Barceló A, Rajpathak S. Incidence and prevalence of diabetes mellitus in the Americas. Rev Panam Salud Publica. 2001;10(5): 300-8. https://doi.org/10.1590/s1020-49892001001100002.

33. Olaiz-Fernandez G, Rojas R, Aguilar-Salinas CA, Rauda J, Villalpando S. Diabetes Mellitus en adultos mexicanos. Resultados de la Encuesta Nacional de Salud 2000. Salud Publica Mex. 2007;49:S331-S7. 
34. Meaney E, Lara-Esqueda A, Ceballos-Reyes GM, Asbun J, Vela A, Martínez-Marroquín Y, et al. Cardiovascular risk factors in the urban Mexican population: the FRIMEX study. Public Health. 2007;121(5):378-84. https://doi.org/10.1016/j.puhe.2006.11.008.

35. Stoddard P, Handley MA, Vargas Bustamante A, Schillinger D. The influence of indigenous status and community indigenous composition on obesity and diabetes among Mexican adults. Soc Sci Med. 2011;73(11):1635-43. https://doi.org/10.1016/j. socscimed.2011.09.006.

36. Secretaría de Salud de México, Instituto Nacional de Salud Pública (INSP). Encuesta Nacional de Salud y Nutricion - 2006 (ENSANUT 2006) (https://ensanut.insp.mx/encuestas/ ensanut2006/index.php). In: Instituto Nacional de Salud Publica SdSdM, editor. Mexico2006. [Last Accessed on August 6, 2020].

37. Kumar A, Wong R, Ottenbacher KJ, Al SS. Prediabetes, undiagnosed diabetes, and diabetes among Mexican adults: findings from the Mexican Health and Aging Study. Ann Epidemiol. 2016;26(3):163-70. https://doi.org/10.1016/j.annepidem.2015. 12.006 .

38. Secretaría de Salud de México, Instituto Nacional de Salud Pública (INSP). Encuesta Nacional de Salud y Nutricion - 2012 (ENSANUT 2012) (https://ensanut.insp.mx/encuestas/ ensanut2012/index.php). In: Instituto Nacional de Salud Publica SdSdM, editor. Mexico2012. [Last Accessed on August 6, 2020].

39. Bello-Chavolla OY, Rojas-Martinez R, Aguilar-Salinas CA, Hernández-Avila M. Epidemiology of diabetes mellitus in Mexico. Nutr Rev. 2017;75(suppl 1):4-12. https://doi.org/10. 1093/nutrit/nuw030.

40. Secretaría de Salud de México, Instituto Nacional de Salud Pública (INSP). Encuesta Nacional de Salud y Nutricion de Medio Camino 2016 (ENSANUT 2016) (https://ensanut.insp. $\mathrm{mx} / \mathrm{encuestas} / \mathrm{ens}$ anut $2016 / \mathrm{doctos} / \mathrm{informes} /$ ENSANUT2016ResultadosNacionales.pdf) (https://www.gob. mx/salud). Mexico, D. F., Mexico2016. [Last Accessed on August 6, 2020].

41. Basto-Abreu A, Barrientos-Gutiérrez T, Rojas-Martínez R, Aguilar-Salinas CA, López-Olmedo N, De la Cruz-Góngora V, et al. Prevalence of diabetes and poor glycemic control in Mexico: results from Ensanut 2016. Salud Publica Mex. 2020;62(1):50-9. https://doi.org/10.21149/10752.

42. Brenes-Camacho G, Rosero-Bixby L. Diabetes mellitus en adultos mayores costarricenses. Poblacion y Salud en Mesoamerica Revista Electronica (https://revistas.ucr.ac.cr/index.php/psm) . 2007;5(1, Article number 2, jul-dic 2007):12. [Last Accessed on October 5, 2020].

43. Brenes-Camacho G, Rosero-Bixby L. Metabolic control in a nationally representative diabetic elderly sample in Costa Rica: patients at community health centers vs patients at other health care settings. BMC Int Health Hum Rights. 2008;8:5. https://doi.org/ 10.1186/1472-698x-8-5.

44. Wong-McClure R, Gregg EW, Barcelo A, Sanabria-Lopez L, Lee $\mathrm{K}$, Abarca-Gomez L, et al. Prevalence of diabetes and impaired fasting glucose in Costa Rica: Costa Rican National Cardiovascular Risk Factors Survey, 2010. J Diabetes. 2016;8(5):686-92. https://doi.org/10.1111/1753-0407.12348.

45. Orantes CM, Herrera R, Almaguer M, Brizuela EG, Núñez L, Alvarado NP, et al. Epidemiology of chronic kidney disease in adults of Salvadoran agricultural communities. MEDICC Rev. 2014;16(2):23-30.

46. Orantes Navarro CM, Herrera Valdés R, López MA, Calero DJ. Fuentes de Morales J, Alvarado Ascencio NP et al. Epidemiological characteristics of chronic kidney disease of non-traditional causes in women of agricultural communities of El Salvador. Clin Nephrol. 2015;83(7 Suppl 1):24-31. https://doi. org/10.5414/cnp83s 024 .
47. Ministerio de Salud de El Salvador. Encuesta Nacional Sobre Enfermedades Cronicas No Transmisibles en la Poblacion Adulta de El Salvador (ENECA-ELS 2015) (https://www.salud. gob.sv/archivos/comunicaciones/archivos_comunicados2017/ pdf/presentaciones evento20032017/01-ENECA-ELS-2015.pdf) (https://www.salud.gob.sv/) . San Salvador, El Salvador2015. [Last Accessed on August 6, 2020].

48. Chen D, Rivera-Andrade Á, González J, Burt D, MendozaMontano C, Patrie J, et al. Prevalence of risk factors for noncommunicable diseases in an indigenous community in Santiago Atitlán, Guatemala. Rev Panam Salud Publica. 2017;41:e7. https://doi.org/10.26633/rpsp.2017.7.

49. Ministerio de Salud Pública y Asistencia Social de Guatemala. Encuesta Nacional de Prevalencia de Enfermedades No Transmisibles y sus Factores de Riesgo en Poblacion de 18 anos o mas. Dominio I: Urbano Metropolitana, Departamento de Guatemala, diciembre 2015 (http://epidemiologia.mspas.gob.gt/ files/Publicaciones\%202019/ENT/STEPS\%20ENT\% 20MSPAS\%202018.pdf) (https://www.mspas.gob.gt/) . Guatemala, Guatemala2018. [Last Accessed on August 6, 2020].

50. Bream KDW, Breyre A, Garcia K, Calgua E, Chuc JM, Taylor L. Diabetes prevalence in rural Indigenous Guatemala: a geographicrandomized cross-sectional analysis of risk. PLoS One. 2018;13(8):e0200434. https://doi.org/10.1371/journal.pone. 0200434.

51. Montalvan Sanchez EE, Urrutia SA, Rodriguez AA, Duarte G, Murillo A, Rivera R, et al. Cardiovascular risk assessment in the resource limited setting of Western Honduras: an epidemiological perspective. Int J Cardiol Heart Vasc. 2020;27:100476. https://doi. org/10.1016/j.ijcha.2020.100476.

52. Laux TS, Bert PJ, González M, Unruh M, Aragon A, Lacourt CT. Prevalence of hypertension and associated risk factors in six Nicaraguan communities. Ethn Dis. 2012;22(2):129-35.

53. Lebov JF, Valladares E, Peña R, Peña EM, Sanoff SL, Cisneros $\mathrm{EC}$, et al. A population-based study of prevalence and risk factors of chronic kidney disease in León. Nicaragua Can J Kidney Health Dis. 2015;2:6. https://doi.org/10.1186/s40697-015-0041-1.

54. Ferguson R, Leatherman S, Fiore M, Minnings K, Mosco M, Kaufman J, et al. Prevalence and risk factors for CKD in the general population of southwestern Nicaragua. J Am Soc Nephrol. 2020;31(7):1585-93. https://doi.org/10.1681/asn. 2019050521

55. Mc Donald PA, Montenegro GJ, Cruz GC, Moreno de Rivera AL, Cumbrera OA. Prevalence, sociodemographic distribution, treatment and control of diabetes mellitus in Panama. Diabetol Metab Syndr. 2013;5(1):69. https://doi.org/10.1186/1758-5996-5-69.

56. Da Silva Coqueiro R, Rodrigues Barbosa A, Ferreti Borgatto A. Nutritional status, health conditions and socio-demographic factors in the elderly of Havana, Cuba: data from SABE survey. $\mathrm{J}$ Nutr Health Aging. 2010;14(10):803-8. https://doi.org/10.1007/ s12603-010-0126-6.

57. Llibre Jde J, Valhuerdi A, Calvo M, García RM, Guerra M, Laucerique T, et al. Dementia and other chronic diseases in older adults in Havana and Matanzas: the 10/66 study in Cuba. MEDICC Rev. 2011;13(4):30-7.

58. Herrera-Valdés R, Almaguer M, Chipi J, Toirac X, Martínez O, Castellanos $\mathrm{O}$, et al. Prevalence of obesity and its association with chronic kidney disease, hypertension and diabetes mellitus. Isle of Youth Study (ISYS), Cuba. MEDICC Rev. 2008;10(2):14-20.

59. Armas NB, Hernández Yde L, Dueñas AF, García Rde L, Castillo A. Cardiovascular risk among older women in a Havana Health Area. MEDICC Rev. 2008;10(2):21-6.

60. Bonet-Gorbea M, Varona P, Chang La Rosa M, Garcia Rocha RG, Suárez-Medina R, Montes de Oca M et al. III Encuesta Nacional de factores de riesgo y actividades preventivas de enfermedades no trasmisibles. Cuba 2010-2011 (https://www. 
researchgate.net/publication/325370475_III_Encuesta_Nacional_ de_factores_de_riesgo_y_actividades_preventivas_de enfermedades no trasmisibles Cuba 2010-2011). La Habana, Cuba: ECIMED - Editorial Ciencias Medicas; 2014. [Last Accessed on August 6, 2020].

61. Ministerio de Salud Pública de la República Dominicana. Encuesta Demografica y de Salud - Republica Dominicana, 2013. 2014. (https://dhsprogram.com/pubs/pdf/FR292/FR292. pdf) [Last Accessed on August 6, 2020].

62. Carrère P, Fagour C, Sportouch D, Gane-Troplent F, HélènePelage J, Lang T, et al. Diabetes mellitus and obesity in the French Caribbean: a special vulnerability for women? Women Health. 2018;58(2):145-59. https://doi.org/10.1080/03630242. 2017.1282396.

63. Jean-Baptiste ED, Larco P, Charles-Larco N, Vilgrain C, Simon $\mathrm{D}$, Charles R. Glucose intolerance and other cardiovascular risk factors in Haiti. Prevalence of diabetes and hypertension in Haiti (PREDIAH). Diabetes Metab. 2006;32(5 Pt 1):443-51. https:// doi.org/10.1016/s1262-3636(07)70302-6.

64. Burkhalter F, Sannon H, Mayr M, Dickenmann M, Ernst S. Prevalence and risk factors for chronic kidney disease in a rural region of Haiti. Swiss Med Wkly. 2014;144:w14067. https://doi. org/10.4414/smw.2014.14067.

65. Ministère de la Santé Publique et de la Population (MSPP) H. Haiti - Enquête Mortalité, Morbidité et Utilisation des Services (EMMUS-VI 2016-2017) (https://www.dhsprogram.com/pubs/ pdf/FR326/FR326.pdf) (https://www.mspp.gouv.ht/ documentation.php? start $=0 \&$ debut $=\&$ fin $=\&$ categorie $=0 \&$ mot $=$ enquete) . In: (MSPP) MdlSPedlP, editor.2018. [Last Accessed on August 6, 2020].

66. Geiss L, Li Y, Kirtland K, Barker L, Burrows NR, Gregg EW. Increasing prevalence of diagnosed diabetes-United States and Puerto Rico, 1995-2010. MMWR Morb Mortal Wkly Rep. 2012;61(45):918-21.

67. Pérez CM, Soto-Salgado M, Suárez E, Guzmán M, Ortiz AP. High prevalence of diabetes and prediabetes and their coexistence with cardiovascular risk factors in a Hispanic Community. J Immigr Minor Health. 2015;17(4):1002-9. https://doi.org/10. 1007/s10903-014-0025-8.

68. Pickens CM, Pierannunzi C, Garvin W, Town M. Surveillance for certain health behaviors and conditions among states and selected local areas - behavioral risk factor surveillance system, United States, 2015. MMWR Surveill Summ. 2018;67(9):1-90. https:// doi.org/10.15585/mmwr.ss6709a1.

69. Cruz NI, Santiago E, Abdul-Hadi A. Prevalence of diabetes mellitus in the surgical population of the University of Puerto Rico Affiliated Hospitals: a study using the surgery database. P R Health Sci J. 2016;35(3):160-4.

70. Ministerio de Salud de Argentina. Segunda Encuesta Nacional de Factores de Riesgo Para Enfermedades No Transmisibles, Argentina 2009 (http://www.msal.gob.ar/images/stories/bes/ graficos $/ 0000001600 \mathrm{cnt}-2 \mathrm{da}$-encuesta-nacional-factores-riesgo 2009_informe-completo.pdf). Buenos Aires, Argentina2011. [Last Accessed on August 6, 2020].

71. Ministerio de Salud de Argentina. Tercera Encuesta Nacional de Factores de Riesgo Para Enfermedades No Transmisibles, Argentina 2013 (http://www.msal.gob.ar/images/stories/bes/ graficos/0000000544cnt-3ra-encuesta-nacional-factores-riesgo 2013_informe-completo.pdf). Buenos Aires, Argentina: 2015. [Last Accessed on August 6, 2020].

72. Ministerio de Salud de Argentina. Cuarta Encuesta Nacional de Factores de Riesgo Para Enfermedades No Transmisibles, 2018 (http://www.msal.gob.ar/images/stories/bes/graficos/ 0000001622cnt-2019-10_4ta-encuesta-nacional-factores-riesgo. pdf). Buenos Aires, Argentina2019. [Last Accessed on August 6, 2020].
73. Barceló A, Daroca MC, Ribera R, Duarte E, Zapata A, Vohra M. Diabetes in Bolivia. Rev Panam Salud Publica. 2001;10(5):318 23. https://doi.org/10.1590/s1020-49892001001100004.

74. Kaplan H, Thompson RC, Trumble BC, Wann LS, Allam AH, Beheim B, et al. Coronary atherosclerosis in indigenous South American Tsimane: a cross-sectional cohort study. Lancet. 2017;389(10080):1730-9. https://doi.org/10.1016/s01406736(17)30752-3.

75. Mendes Tde A, Goldbaum M, Segri NJ, Barros MB, Cesar CL, Carandina L, et al. Diabetes mellitus: factors associated with prevalence in the elderly, control measures and practices, and health services utilization in São Paulo, Brazil. Cad Saude Publica. 2011;27(6):1233-43. https://doi.org/10.1590/s0102$311 \times 2011000600020$.

76. Schmidt MI, Hoffmann JF, de Fátima Sander Diniz M, Lotufo PA, Griep RH, Bensenor IM, et al. High prevalence of diabetes and intermediate hyperglycemia - The Brazilian Longitudinal Study of Adult Health (ELSA-Brasil). Diabetol Metab Syndr. 2014;6:123. https://doi.org/10.1186/1758-5996-6-123.

77. Dal Fabbro AL, Franco LJ, da Silva AS, Sartorelli DS, Soares LP, Franco LF, et al. High prevalence of type 2 diabetes mellitus in Xavante Indians from Mato Grosso. Brazil Ethn Dis. 2014;24(1): 35-40.

78. Ministério do Planejamento Orçamento e Gestão, -IBGE. Pesquisa Nacional de Saude 2013. Percepcao do estado de saude, estilos de vida e doencas cronicas. (https://www.saude.gov.br/ vigilancia-em-saude/vigilancia-de-doencas-cronicas-naotransmissiveis-dent/pesquisa-nacional-de-saude-pns). Rio de Janeiro, Brazil: Instituto Brasileiro de Geografia e Estatistica IBGE; 2014. [Last Accessed on August 6, 2020].

79. de Oliveira AP, Maia EG, Silva FM, Martins APB, Claro RM. Needed Improvements in Diabetes Prevention and Management in Brazil. Prev Chronic Dis. 2018;15:E153. https://doi.org/10. 5888/pcd15.180269.

80. Ministério da Saúde do Brasil. Vigilância de Fatores de Risco e Proteção para Doenças Crônicas por Inquérito Telefônico (VIGITEL BRASIL 2018) (https://portalarquivos2.saude.gov.br/ images/pdf/2019/julho/25/vigitel-brasil-2018.pdf) (http://bvsms. saude.gov.br/bvs/publicacoes/vigitel_brasil_2018_vigilancia fatores_risco.pdf). Brasilia, Brazil: 2019. [Last Accessed on August 6, 2020].

81. Ministério da Saúde do Brasil. Vigilância de Fatores de Risco e Proteção para Doenças Crônicas por Inquérito Telefônico (VIGITEL BRASIL 2019) (https://portalarquivos.saude.gov.br/ images/pdf/2020/April/27/vigitel-brasil-2019-vigilancia-fatoresrisco.pdf) (http://bvsms.saude.gov.br/bvs/publicacoes/vigitel_ brasil 2019 vigilancia fatores risco.pdf). Brasilia, Brazil: 2019. [Last Accessed on August 6, 2020].

82. Santos JL, Pérez-Bravo F, Carrasco E, Calvillán M, Albala C. Low prevalence of type 2 diabetes despite a high average body mass index in the Aymara natives from Chile. Nutrition. 2001;17(4):305-9. https://doi.org/10.1016/s0899-9007(00) 00551-7.

83. Carrasco EP, Pérez FB, Angel BB, Albala CB, Santos JL, Larenas GY, et al. Prevalence of type 2 diabetes and obesity in two Chilean aboriginal populations living in urban zones. Rev Med Chil. 2004;132(10):1189-97. https://doi.org/10.4067/s003498872004001000005 .

84. Cuevas A, Molina A, Rigotti A, Miquel JF, Marshall G, Reyes S, et al. Trends in obesity and diabetes prevalence in a Chilean urban population: 1993-2001. Metab Syndr Relat Disord. 2008;6(3): 219-22. https://doi.org/10.1089/met.2008.0018.

85. Ministerio de Salud de Chile. Encuesta Nacional de Salud, ENS Chile 2009-2010 (https://cursoemergencia.files.wordpress.com/ 2013/04/encuesta-nacional-de-salud-2009-2010.pdf) (https:// 
www.minsal.cl/) (http://epi.minsal.cl/resultados-encuestas/). Santiago, Chile2009-2010. [Last Accessed on August 6, 2020].

86. Ministerio de Salud de Chile. Encuesta Nacional de Salud 20162017 (https://www.minsal.cl/tercera-encuesta-nacional-de-saludestablece-prioridades-sanitarias-para-la-proxima-decada/) (https:// www.minsal.cl/) (http://epi.minsal.cl/resultados-encuestas/). Santiago, Chile2016-2017. [Last Accessed on August 6, 2020].

87. Rodriguez J, Ruiz F, Penaloza E, Eslava J, Gomez LC, Sanchez H et al. Encuesta Nacional de Salud 2007. Resultados Nacionales (https://www.minsalud.gov.co/Documentos\%20y\% 20Publicaciones/ENCUESTA\%20NACIONAL.pdf). (https:// www.minsalud.gov.co/Paginas/default.aspx). Bogota, Colombia: Fundacion Cultural Javeriana de Artes Graficas -JAVEGRAF-; 2009. [Last Accessed on August 6, 2020].

88. Camacho PA, Gomez-Arbelaez D, Otero J, González-Gómez S, Molina DI, Sanchez G, et al. Self-reported prevalence of chronic non-communicable diseases in relation to socioeconomic and educational factors in Colombia: a community-based study in 11 departments. Glob Heart. 2020;15(1):35. https://doi.org/10.5334/ gh.792.

89. Profamilia. Encuesta Nacional de Demografia y Salud (ENDS 2010). Bogota, Colombia: Printex Impresores, Ltda.; 2011.

90. Orces $\mathrm{CH}$, Lorenzo C. Prevalence of prediabetes and diabetes among older adults in Ecuador: analysis of the SABE survey. Diabetes Metab Syndr. 2018;12(2):147-53. https://doi.org/10. 1016/j.dsx.2017.12.002.

91. Ministerio de Salud Pública de Ecuador. Encuesta Nacional de Salud y Nutricion del Ecuador: ENSANUT-ECU 2012 (https:// www.ecuadorencifras.gob.ec/documentos/web-inec/Estadisticas Sociales/ENSANUT/MSP_ENSANUT-ECU_06-10-2014.pdf) [Last Accessed on August 6, 2020] (https://www.salud.gob.ec/). Quito, Ecuador2013.

92. Tufton N, Chowdhury T. Prevalence of diabetes on Santa Cruz Island in Galapagos Archipelago. Prev Chronic Dis. 2015;12:E94. https://doi.org/10.5888/pcd12.150108.

93. Alexander A, Florez H, Ladera N. Hyperglycemia and dyslipidemia of Isabela, Galápagos, Ecuador: a pilot study of cardiovascular risk factors in an Isolated Island community. Diabetes Res Clin Pract. 2017;130:108-12. https://doi.org/10.1016/j.diabres. 2017.05.015.

94. Bonilla-Sierra P, Vargas-Martínez AM, Davalos-Batallas V, Leon-Larios F, Lomas-Campos MD. Chronic diseases and associated factors among older adults in Loja, Ecuador. Int J Environ Res Public Health. 2020;17(11). https://doi.org/10.3390/ ijerph17114009.

95. Chaves G, Brítez N, Maciel V, Klinkhof A, Mereles D. Prevalence of cardiovascular risk factors in an urban ambulatory adult population: AsuRiesgo study, Paraguay. Rev Panam Salud Publica. 2015;38(2):136-43.

96. Ministerio de Salud Pública y Bienestar Social de Paraguay. Primera Encuesta Nacional de Factores de Riesgo de Enfermedades No Transmisibles en Poblacion General (http:// portal.mspbs.gov.py/dvent/encuesta-nacional-factores-de-riesgo2011/) (www.mspbs.gov.py). Asuncion, Paraguay2012. [Last Accessed on August 6, 2020].

97. Segura-Vega L. Agusti, R., Parodi-Ramirez, J., e investigadores del estudio TORNASOL. Factores de Riesgo de las Enfermedades Cardiovasculares en el Peru (Estudio TORNASOL). Rev Peruana Cardiol. 2006;32(2):82-128.

98. Ministerio de Salud de Peru. Encuesta Nacional de Indicadores Nutricionales, Bioquimicos, Socioeconomicos y Culturales Relacionados con las Enfermedades Cronico Degenerativas (ENINBSC-ECNT 2005) (https://www.ins.gob.pe/insvirtual/ BiblioDig/MISC/ENIN/IFENIN.pdf) (https://www.gob.pe/ minsa/). In: Peru MoHo, editor. Lima, Peru2006. [Last Accessed on August 6, 2020].
99. Miranda JJ, Gilman RH, Smeeth L. Differences in cardiovascular risk factors in rural, urban and rural-to-urban migrants in Peru. Heart. 2011;97(10):787-96. https://doi.org/10.1136/hrt.2010. 218537.

100. Segura-Vega L, Agusti R, Ruiz-Mori E, e investigadores del Estudio. Factores de Riesgo de las enfermedades cardiovasculares en el Peru II. Estudio TORNASOL II comparado con TORNASOL I despues de cinco anos. Rev Peruana Cardiol. 2013;39(1):6-59.

101. Seclen SN, Rosas ME, Arias AJ, Huayta E, Medina CA. Prevalence of diabetes and impaired fasting glucose in Peru: report from PERUDIAB, a national urban population-based longitudinal study. BMJ Open Diabetes Res Care. 2015;3(1):e000110. https://doi.org/10.1136/bmjdrc-2015-000110.

102. Bernabé-Ortiz A, Carrillo-Larco RM, Gilman RH, Miele CH, Checkley W, Wells JC, et al. Geographical variation in the progression of type 2 diabetes in Peru: The CRONICAS Cohort Study. Diabetes Res Clin Pract. 2016;121:135-45. https://doi. org/10.1016/j.diabres.2016.09.007.

103. Krishnadath IS, Smits CC, Jaddoe VW, Hofman A, Toelsie JR. A National surveillance survey on noncommunicable disease risk factors: suriname health study protocol. JMIR Res Protoc. 2015;4(2):e75. https://doi.org/10.2196/resprot.4205.

104. Minderhoud J, Pawiroredjo JC. Bueno de Mesquita-Voigt AM, Themen HC, Siban MR, Forster-Pawiroredjo CM et al. Diabetes and diabetic retinopathy in people aged 50 years and older in the Republic of Suriname. Br J Ophthalmol. 2016;100(6):814-8. https://doi.org/10.1136/bjophthalmol-2015-307177.

105. Ministerio de Salud Pública del Uruguay. Primera Encuesta Nacional de Factores de Riesgo de Enfermedades Cronicas No Transmisibles - ENFRECNT (https://www.gub.uy/ministeriosalud-publica/comunicacion/publicaciones/primera-encuestanacional-de-factores-de-riesgo-de-enfermedades-cronicas). 2006. [Last Accessed on August 6, 2020].

106. Fort MP, Alvarado-Molina N, Peña L, Mendoza Montano C, Murrillo S, Martínez H. Barriers and facilitating factors for disease self-management: a qualitative analysis of perceptions of patients receiving care for type 2 diabetes and/or hypertension in San José, Costa Rica and Tuxtla Gutiérrez. Mexico BMC Fam Pract. 2013;14:131. https://doi.org/10.1186/1471-2296-14-131.

107. Ministerio de Salud Pública del Uruguay. Segunda Encuesta Nacional de Factores de Riesgo de Enfermedades No Transmisibles - ENFRENT (https://www.gub.uy/ministeriosalud-publica/comunicacion/publicaciones/2da-encuestanacional-de-factores-de-riesgo-de-enfermedades-no). 2016. [Last Accessed on August 6, 2020].

108. Nieto-Martínez R, Mechanick JI, Brajkovich I, Ugel E, Risques A, Florez H, et al. Prevalence of diabetes in three regions of Venezuela. The VEMSOLS study results. Prim Care Diabetes. 2018;12(2):126-32. https://doi.org/10.1016/j.pcd.2017.11.005.

109. Menéndez J, Guevara A, Arcia N, León Díaz EM, Marín C, Alfonso JC. Chronic diseases and functional limitation in older adults: a comparative study in seven cities of Latin America and the Caribbean. Rev Panam Salud Publica. 2005;17(5-6):353-61. https://doi.org/10.1590/s1020-49892005000500007.

110. Escobedo J, Buitrón LV, Velasco MF, Ramírez JC, Hernández R, Macchia A, et al. High prevalence of diabetes and impaired fasting glucose in urban Latin America: the CARMELA Study. Diabet Med. 2009;26(9):864-71. https://doi.org/10.1111/j.1464-5491. 2009.02795.x.

111. Barcelo A, Gregg EW, Gerzoff RB, Wong R, Perez Flores E, Ramirez-Zea M, et al. Prevalence of diabetes and intermediate hyperglycemia among adults from the first multinational study of noncommunicable diseases in six Central American countries: the Central America Diabetes Initiative (CAMDI). Diabetes Care. 2012;35(4):738-40. https://doi.org/10.2337/dc11-1614. 
112. Salas A, Acosta D, Ferri CP, Guerra M, Huang Y, Jacob KS, et al. The Prevalence, correlates, detection and control of diabetes among older people in low and middle income countries. a 10/ 66 Dementia Research Group Population-Based survey. PLoS One. 2016;11(2):e0149616. https://doi.org/10.1371/journal.pone. 0149616.

113. Rubinstein AL, Irazola VE, Calandrelli M, Elorriaga N, Gutierrez $\mathrm{L}$, Lanas F, et al. Multiple cardiometabolic risk factors in the Southern Cone of Latin America: a population-based study in Argentina, Chile, and Uruguay. Int J Cardiol. 2015;183:82-8. https://doi.org/10.1016/j.ijcard.2015.01.062.

114. Macinko J, Andrade FCD, Nunes BP, Guanais FC. Primary care and multimorbidity in six Latin American and Caribbean countries. Rev Panam Salud Publica. 2019;43:e8. https://doi.org/10. 26633/rpsp.2019.8.

115. American Diabetes Association. 2. Classification and diagnosis of diabetes: <em>Standards of Medical Care in Diabetes-2020</ em>. Diabetes Care. 2020;43(Supplement 1):S14-S31. https:// doi.org/10.2337/dc20-S002.

116. Camejo M, Garcia A, Rodriguez E, Carrizales M. E., Chique, J. Vision Epidemiologica de la Diabetes Mellitus en Venezuela. Registro Epidemiologico y Propuesta de Registro. Programas de Deteccion Precoz. Rev Venez Endocrinol Metabol. 2012;10:2-6.

117. Rubinstein A, Gutierrez L, Beratarrechea A, Irazola VE. Increased prevalence of diabetes in Argentina is due to easier health care access rather than to an actual increase in prevalence. PLoS One. 2014;9(4):e92245. https://doi.org/10.1371/journal.pone.0092245.

118. Coutinho WF, Silva Júnior WS. Diabetes Care in Brazil. Ann Glob Health. 2015;81(6):735-41. https://doi.org/10.1016/j.aogh. 2015.12.010.

119. Nieto-Martínez R, González-Rivas JP, Lima-Martínez M, Stepenka V, Rísquez A, Mechanick JI. Diabetes Care in Venezuela. Ann Glob Health. 2015;81(6):776-91. https://doi. org/10.1016/j.aogh.2015.11.002.

120. Mc Donald Posso AJ, Bradshaw Meza RA, Mendoza Morales EA, Jaen Y, Cumbrera Ortega A, Mendoza Posada EJ. Diabetes in Panama: epidemiology, risk factors, and clinical management. Ann Glob Health. 2015;81(6):754-64. https://doi.org/10.1016/j. aogh.2015.12.014.

121. Villena JE. Diabetes Mellitus in Peru. Ann Glob Health. 2015;81(6):765-75. https://doi.org/10.1016/j.aogh.2015.12.018.

122. Telo GH, Cureau FV, de Souza MS, Andrade TS, Copês F, Schaan BD. Prevalence of diabetes in Brazil over time: a systematic review with meta-analysis. Diabetol Metab Syndr. 2016;8(1): 65. https://doi.org/10.1186/s13098-016-0181-1.

123. Carrillo-Larco RM, Bernabé-Ortiz A. Type 2 diabetes mellitus in peru: a systematic review of prevalence and incidence in the general population. Rev Peru Med Exp Salud Publica. 2019;36(1):2636. https://doi.org/10.17843/rpmesp.2019.361.4027.

124. Barceló A. Diabetes in the Americas. Epidemiol Bull. 2001;22(2): $1-3$.

125. Bello-Chavolla OY, Aguilar-Salinas CA. Diabetes in Latin America. In: Dagogo-Jack S, editor. Diabetes mellitus in developing countries and underserved communities. Cham: Springer International Publishing; 2017. p. 101-26.

126. Burroughs Pena MS, Bernabé-Ortiz A, Carrillo-Larco RM, Sánchez JF, Quispe R, Pillay TD, et al. Migration, urbanisation and mortality: 5-year longitudinal analysis of the PERU MIGRANT study. J Epidemiol Community Health. 2015;69(7): 715-8. https://doi.org/10.1136/jech-2015-205657.

127. Ruiz-Alejos A, Carrillo-Larco RM, Miranda JJ, Anderson CAM, Gilman RH, Smeeth L, et al. Addressing the impact of urban exposure on the incidence of type 2 diabetes mellitus: The PERU MIGRANT Study. Sci Rep. 2018;8(1):5512. https://doi. org/10.1038/s41598-018-23812-6.
128. Carrera Boada CA, Martínez-Moreno JM. Pathophysiology of diabetes mellitus type 2: beyond the duo "insulin resistancesecretion deficit". Nutr Hosp. 2013;28(Suppl 2):78-87. https:// doi.org/10.3305/nh.2013.28.sup2.6717.

129. Mendenhall E, Kohrt BA, Norris SA, Ndetei D, Prabhakaran D. Non-communicable disease syndemics: poverty, depression, and diabetes among low-income populations. Lancet. 2017;389(10072):951-63. https://doi.org/10.1016/s01406736(17)30402-6.

130. Albala C, Vio F, Kain J, Uauy R. Nutrition transition in Latin America: the case of Chile. Nutr Rev. 2001;59(6):170-6. https:// doi.org/10.1111/j.1753-4887.2001.tb07008.x.

131. Carrillo-Larco RM, Pearson-Stuttard J, Bernabe-Ortiz A, Gregg EW. The Andean Latin-American burden of diabetes attributable to high body mass index: a comparative risk assessment. Diabetes Res Clin Pract. 2020;160:107978. https://doi.org/10.1016/j. diabres.2019.107978.

132. Abu-Bakare A, Taylor R, Gill GV, Alberti KG. Tropical or malnutrition-related diabetes: a real syndrome? Lancet. 1986;1(8490):1135-8. https://doi.org/10.1016/s0140-6736(86) 91846-5.

133. Morrison EY, Ragoobirsingh D, Peter SA. The unitarian hypothesis for the aetiology of diabetes mellitus. Med Hypotheses. 2006;67(5):1115-20. https://doi.org/10.1016/j.mehy.2006.04. 061.

134. Llanos G, Libman I. Diabetes in the Americas. Bull Pan Am Health Organ. 1994;28(4):285-301.

135. Wissow LS. Diabetes, poverty, and Latin America. Patient Educ Couns. 2006;61(2):169-70. https://doi.org/10.1016/j.pec.2006. 03.007 .

136. McCurley JL, Mills PJ, Roesch SC, Carnethon M, Giacinto RE, Isasi CR, et al. Chronic stress, inflammation, and glucose regulation in U.S. Hispanics from the HCHS/SOL Sociocultural Ancillary Study. Psychophysiology. 2015;52(8):1071-9. https:// doi.org/10.1111/psyp.12430.

137. Lopez-Jaramillo P, Lahera V, Lopez-Lopez J. Epidemic of cardiometabolic diseases: a Latin American point of view. Ther Adv Cardiovasc Dis. 2011;5(2):119-31. https://doi.org/10.1177/ 1753944711403189

138. Frenk J, Frejka T, Bobadilla JL, Stern C, Lozano R, Sepúlveda J, et al. The epidemiologic transition in Latin America. Bol Oficina Sanit Panam. 1991;111(6):485-96.

139. Mendoza W, Miranda JJ. Global shifts in cardiovascular disease, the epidemiologic transition, and other contributing factors: toward a new practice of global health cardiology. Cardiol Clin. 2017;35(1):1-12. https://doi.org/10.1016/j.ccl.2016.08.004.

140. Meslé F, Vallin J. From epidemiological transition to health transition. Med Trop (Mars). 2007;67(6):545-51.

141. Barreto SM, Miranda JJ, Figueroa JP, Schmidt MI, Munoz S, Kuri-Morales PP, et al. Epidemiology in Latin America and the Caribbean: current situation and challenges. Int J Epidemiol. 2012;41(2):557-71. https://doi.org/10.1093/ije/dys017.

142. Chomsky-Higgins K, Miclau TA, Mackechnie MC, Aguilar D, Avila JR, Dos Reis FB, et al. Barriers to Clinical Research in Latin America. Front Public Health. 2017;5:57. https://doi.org/ 10.3389/fpubh.2017.00057.

143. Owolabi M, Miranda JJ, Yaria J, Ovbiagele B. Controlling cardiovascular diseases in low and middle income countries by placing proof in pragmatism. BMJ Glob Health. 2016;1(3). https://doi.org/ 10.1136/bmjgh-2016-000105.

144. Lazo-Porras M, Perez-Leon S, Cardenas MK, Pesantes MA, Miranda JJ, Suggs LS, et al. Lessons learned about co-creation: developing a complex intervention in rural Peru. Glob Health Action. 2020;13(1):1754016. https://doi.org/10.1080/16549716. 2020.1754016. 
145. Afshin A, Micha R, Webb M, Capewell S, Whitsel L, Rubinstein A, et al. Effectiveness of dietary policies to reduce noncommunicable diseases. In: Prabhakaran D, Anand S, Gaziano TA, Mbanya JC, Wu Y, Nugent R, editors. Cardiovascular, Respiratory, and Related Disorders. Washington: The International Bank for Reconstruction and Development / The World Bank (C) 2017 International Bank for Reconstruction and Development / The World Bank; 2017.

146. Franco M, Orduñez P, Caballero B, Tapia Granados JA, Lazo M, Bernal JL, et al. Impact of energy intake, physical activity, and population-wide weight loss on cardiovascular disease and diabetes mortality in Cuba, 1980-2005. Am J Epidemiol. 2007;166(12):1374-80. https://doi.org/10.1093/aje/kwm226.

147. Kaselitz E, Rana GK, Heisler M. Public Policies and Interventions for Diabetes in Latin America: a Scoping Review. Curr Diab Rep. 2017;17(8):65. https://doi.org/10.1007/s11892-017-0888-x.

148. Posner BM, Quatromoni PA, Franz M. Nutrition policies and interventions for chronic disease risk reduction in international settings: the INTERHEALTH nutrition initiative. Nutr Rev. 1994;52(5):179-87. https://doi.org/10.1111/j.1753-4887.1994. tb01417.x.

149. Rubinstein AL, Irazola VE, Poggio R, Gulayin P, Nejamis A, Beratarrechea A. Challenges and opportunities for implementation of interventions to prevent and control CVD in low-resource settings: a report from CESCAS in Argentina. Glob Heart. 2015;10(1):21-9. https://doi.org/10.1016/j.gheart.2014.12.011.

150. Siqueira-Catania A, Cezaretto A, de Barros CR, Salvador EP, Dos Santos TC, Ferreira SR. Cardiometabolic risk reduction through lifestyle intervention programs in the Brazilian public health system. Diabetol Metab Syndr. 2013;5:21. https://doi.org/10.1186/ 1758-5996-5-21.

151. Solomons NW. Programme and policy issues related to promoting positive early nutritional influences to prevent obesity, diabetes and cardiovascular disease in later life: a developing countries view. Matern Child Nutr. 2005;1(3):204-15. https://doi.org/10. 1111/j.1740-8709.2005.00030.x.

152. Fisberg M, Kovalskys I, Salas GG, Pareja Torres RG, Yépez García MC, Cortés Sanabria LY, et al. Developing a cooperative multicenter study in Latin America: lessons learned from the Latin American Study of Nutrition and Health Project. Rev Panam Salud Publica. 2017;41:e111. https://doi.org/10.26633/rpsp. 2017.111.

153. Werneck AO, Baldew SS, Miranda JJ, Díaz Arnesto O, Stubbs B, Silva DR. Physical activity and sedentary behavior patterns and sociodemographic correlates in 116,982 adults from six South American countries: the South American physical activity and sedentary behavior network (SAPASEN). Int J Behav Nutr Phys Act. 2019;16(1):68. https://doi.org/10.1186/s12966-019-0839-9.

154. Diez Roux AV, Slesinski SC, Alazraqui M, Caiaffa WT, Frenz P, Jordán Fuchs R, et al. A novel international partnership for actionable evidence on urban health in Latin America: LAC-Urban Health and SALURBAL. Global Chall. 2019;3(4):1800013. https://doi.org/10.1002/gch2.201800013.

155. Taype-Rondan A, Lazo-Porras M, Moscoso-Porras M, MoreanoSáenz M, Miranda JJ. Inadequate glycaemic control in LMIC: health system failures in Peru. Br J Gen Pract. 2016;66(645): 197. https://doi.org/10.3399/bjgp16X684541.

156. Beran D, Miranda JJ, Cardenas MK, Bigdeli M. Health systems research for policy change: lessons from the implementation of rapid assessment protocols for diabetes in low- and middleincome settings. Health Res Policy Syst. 2015;13:41. https://doi. org/10.1186/s12961-015-0029-4.

157. Cardenas MK, Miranda JJ, Beran D. Delivery of Type 2 diabetes care in low- and middle-income countries: lessons from Lima. Peru Diabet Med. 2016;33(6):752-60. https://doi.org/10.1111/ dme.13099.
158. Escalante M, Gagliardino JJ, Guzmán JR, Tschiedel B. Call-toaction: timely and appropriate treatment for people with type 2 diabetes in Latin America. Diabetes Res Clin Pract. 2014;104(3): 343-52. https://doi.org/10.1016/j.diabres.2014.01.004.

159. López-López E, Gutiérrez-Soria D, Idrovo AJ. Evaluation of a diabetes care program using the effective coverage framework. Int J Qual Health Care. 2012;24(6):619-25. https://doi.org/10. 1093/intqhe/mzs056.

160. Flores-Hernández S, Saturno-Hernández PJ, Reyes-Morales H, Barrientos-Gutiérrez T, Villalpando S, Hernández-Ávila M. Quality of Diabetes Care: The challenges of an increasing epidemic in Mexico. Results from two national health surveys (2006 and 2012). PLoS One. 2015;10(7):e0133958. https://doi.org/10.1371/ journal.pone.0133958.

161. Fanghänel Salmón G, Sánchez-Reyes L, Chiquete Anaya E, de la Luz CJ, Escalante HA. Multicenter international registry to evaluate the clinical practice delivered to patients with type 2 diabetes mellitus: a sub-analysis of the experience in Mexico. Gac Med Mex. 2011;147(3):226-33.

162. Hernández-Romieu AC, Elnecavé-Olaiz A, Huerta-Uribe N, Reynoso-Noverón N. Analysis of population survey for determining the factors associated with the control diabetes mellitus in Mexico. Salud Publica Mex. 2011;53(1):34-9. https://doi.org/ 10.1590/s0036-36342011000100006.

163. Lavalle-González FJ, Chiquete E, de la Luz J, Ochoa-Guzmán A, Sánchez-Orozco LV, Godínez-Gutiérrez SA. Achievement of therapeutic targets in Mexican patients with diabetes mellitus. Endocrinol Nutr. 2012;59(10):591-8. https://doi.org/10.1016/j. endonu.2012.07.005.

164. Wacher NH, Silva M, Valdez L, Cruz M, Gómez-Díaz RA. Poor metabolic control in primary care. Gac Med Mex. 2016;152(3): $350-6$

165. Gough E, Emmanuel E, Jenkins V, Thompson L, Perez E, Barcelo A et al. Central America Diabetes Initiative (CAMDI): survey of diabetes, hyperntion and chronic disease risk factor, Belize (https://www.paho.org/hq/dmdocuments/2012/PAHO-CAMDIReport-BELIZE-2009.pdf) (https://www.paho.org/hq/index.php? option $=$ com_docman\&view $=$ list $\&$ format $=h t m l \& l$ layout $=$ default\&slug=reports-4402\&Itemid=270\&lang=fr). Belize City, Belize: Pan American Health Organization (PAHO); 2009. [Last Accessed on August 6, 2020].

166. Dekker AM, Amick AE, Scholcoff C, Doobay-Persaud A. A mixed-methods needs assessment of adult diabetes mellitus (type II) and hypertension care in Toledo. Belize BMC Health Serv Res. 2017;17(1):171. https://doi.org/10.1186/s12913-017-2075-9.

167. Ministerio de Salud, Caja Costarricense del Seguro Social, Organización Panamericana de la Salud. Encuesta de Diabetes, Hipertension y Factores de Riesgo de Enfermedades Cronicas, San Jose, Costa Rica, 2004. (https://www.paho.org/hq/ dmdocuments/2012/OPS-CAMDI-COSTA-RICA-2009.pdf) (https://www.paho.org/hq/index.php?option =com docman $\&$ view $=$ list $\&$ format $=h t m 1 \&$ layout $=$ default $\&$ slug $=$ reports-4402\&Itemid=270\&lang=fr). 2009. [Last Accessed on August 6, 2020].

168. Organización Panamericana de la Salud. Iniciativa Centroamericana de Diabetes (CAMDI): Encuesta de Diabetes, Hipertension y Factores de Riesgo de Enfermedades Cronicas. Tegucigalpa, Honduras, 2004. (https://www.paho.org/hq/ dmdocuments/2010/ENCUESTA DE DIABETES HONDURAS.pdf) (https://www.paho.org/hq/index.php? option=com_content\&view=article \&id=3070:2010-survey-ondiabetes-hypertension-chronic-disease-risk-factors-centralamerica\&Itemid $=1353 \&$ lang=en\#surveys ). 2009. [Last Accessed on August 6, 2020].

169. Orellana Pontaza P, Ramirez-Zea M, Barcelo A, Gil E, Gregg EW, Meiners $M$ et al. Iniciativa Centroamericana de Diabetes 
(CAMDI): Encuesta de Diabetes, Hipertension y Factores de Riesgo de Enfermedades Cronicas, Villa Nueva, Guatemala, 2006 (https://www.paho.org/hq/dmdocuments/2012/PAHOCAMDI-Guatemala-2009.pdf) (https://www.paho.org/hq/index. php?option $=$ com docman \&view $=$ list $\&$ format $=\mathrm{html} \&$ layout $=$ default\&slug=reports-4402\&Itemid=270\&lang=fr). Washington, D.C.: Organizacion Panamericana de la Salud; 2007. [Last Accessed on August 6, 2020].

170. Amador Velazquez JJ, Pastora Arostegui M, Barcelo A, Aldighieri S, Gregg EW, Pena R et al. Iniciativa Centromericana de Diabetes (CAMDI). Encuesta de Diabetes, Hipertension y Factores de Riesgo de Enfermedades Cronicas. Managua, Nicaragua, 2010. (https://www.paho.org/hq/ index.php?option $=$ com_content $\&$ view $=$ article $\&$ id $=3070: 2010$ survey-on-diabetes-hypertension-chronic-disease-risk-factorscentral-america\&Itemid=1353\&lang=en\#surveys) $(\mathrm{https}: / \mathrm{www}$. paho.org/hq/index.php?option=com_content $\&$ view $=$ article \&id $=$ 3040:2010-encuesta-diabetes-factores-managuanicaragua\&Itemid $=1353 \&$ lang $=e n)$. Washington, D. C.: Pan American Health Organization; 2010. [Last Accessed on August 6, 2020].

171. Dethlefs HJ, Walker EA, Schechter CB, Dowd R, Filipi L, Garcia $\mathrm{JF}$, et al. Evaluation of a program to improve intermediate diabetes outcomes in rural communities in the Dominican Republic. Diabetes Res Clin Pract. 2019;148:212-21. https://doi.org/10. 1016/j.diabres.2019.01.010.

172. Pérez CM, Febo-Vázquez I, Guzmán M, Ortiz AP, Suárez E. Are adults diagnosed with diabetes achieving the American Diabetes Association clinical practice recommendations? P R Health Sci J. 2012;31(1):18-23

173. Rodríguez-Vigil E, Rodríguez-Chacón M, Trabanco C, IrizarryRamos J. Achievement of national clinical practice recommendations among those in the Puerto Rican population with diabetes mellitus. P R Health Sci J. 2014;33(4):157-62.

174. Gagliardino JJ, Elgart J, Forti L, Guaita MS, Chantelot JM. Treatto-target $\mathrm{HbA}(1 \mathrm{c})$ and lipid profile to prolong $\beta$-cell mass/function and optimize treatment goal attainment. Diabetes Metab Res Rev. 2019;35(6):e3166. https://doi.org/10.1002/dmrr.3166.

175. Santero M, Morelli D, Nejamis A, Gibbons L, Irazola V, Beratarrechea A. Using mHealth strategies in a Diabetes Management Program to improve the quality of care in Argentina: Study design and baseline data. Prim Care Diabetes. 2018;12(6):510-6. https://doi.org/10.1016/j.pcd.2018.07.014.

176. Gomes MB, Gianella D, Faria M, Tambascia M, Fonseca RM, Réa R, et al. Prevalence of Type 2 diabetic patients within the targets of care guidelines in daily clinical practice: a multi-center study in Brazil. Rev Diabet Stud. 2006;3(2):82-7. https://doi.org/ 10.1900/rds.2006.3.82.

177. Mendes AB, Fittipaldi JA, Neves RC, Chacra AR, Moreira ED Jr. Prevalence and correlates of inadequate glycaemic control: results from a nationwide survey in 6,671 adults with diabetes in Brazil. Acta Diabetol. 2010;47(2):137-45. https://doi.org/10.1007/ s00592-009-0138-z.

178. Moraes HAB, Mengue SS, Molina M, Cade NV. Factors associated with glycemic control in a sample of individuals with Diabetes Mellitus taken from the Longitudinal Study of Adult Health, Brazil, 2008-2010. Epidemiol Serv Saude. 2020;29(3): e2018500. https://doi.org/10.5123/s1679-49742020000300017.

179. Viana LV, Leitão CB, Kramer CK, Zucatti AT, Jezini DL, Felício $\mathrm{J}$, et al. Poor glycaemic control in Brazilian patients with type 2 diabetes attending the public healthcare system: a cross-sectional study. BMJ Open. 2013;3(9):e003336. https://doi.org/10.1136/ bmjopen-2013-003336.

180. Baptista DR, Thieme RD, Reis WC, Pontarolo R, Correr CJ. Proportion of Brazilian diabetes patients that achieve treatment goals: implications for better quality of care. Diabetol Metab Syndr. 2015;7:113. https://doi.org/10.1186/s13098-015-0107-3.

181. Alba LH, Bastidas C, Vivas JM, Gil F. Prevalence of glycemic control and associated factors in type 2 diabetes mellitus patients at the Hospital Universitario de San Ignacio, Bogotá-Colombia. Gac Med Mex. 2009;145(6):469-74.

182. Machado-Alba JE, Moncada-Escobar JC, Gaviria H. Quality and effectiveness of diabetes care for a group of patients in Colombia. Rev Panam Salud Publica. 2009;26(6):529-35. https://doi.org/10. 1590/s1020-49892009001200008.

183. Fort Z. Factores de riesgo cardiovascular en 74.420 solicitantes de carne de salud. Rev Urug Cardiol. 2012;27:150-61.

184. Gagliardino JJ, de la Hera M, Siri F. Evaluation of the quality of care for diabetic patients in Latin America. Rev Panam Salud Publica. 2001;10(5):309-17. https://doi.org/10.1590/s102049892001001100003.

185. Silva H, Hernandez-Hernandez R, Vinueza R, Velasco M, Boissonnet CP, Escobedo J, et al. Cardiovascular risk awareness, treatment, and control in urban Latin America. Am J Ther. 2010;17(2):159-66. https://doi.org/10.1097/MJT. 0b013e3181a84ec5.

186. Commendatore V, Dieuzeide G, Faingold C, Fuente G, Luján D, Aschner P, et al. Registry of people with diabetes in three Latin American countries: a suitable approach to evaluate the quality of health care provided to people with type 2 diabetes. Int J Clin Pract. 2013;67(12):1261-6. https://doi.org/10.1111/ijcp.12208.

187. Lopez Stewart G, Tambascia M, Rosas Guzmán J, Etchegoyen F, Ortega Carrión J, Artemenko S. Control of type 2 diabetes mellitus among general practitioners in private practice in nine countries of Latin America. Rev Panam Salud Publica. 2007;22(1):12-20. https://doi.org/10.1590/s1020-49892007000600002.

188. F GD, da Silva Moreira S, Almeida M, de Souza Teles CA, Andrade CS, Reingold AL, et al. Sex differences and correlates of poor glycaemic control in type 2 diabetes: a cross-sectional study in Brazil and Venezuela. BMJ Open. 2019;9(3):e023401. https://doi.org/10.1136/bmjopen-2018-023401.

189. Irazola V, Rubinstein A, Bazzano L, Calandrelli M, ChungShiuan C, Elorriaga N, et al. Prevalence, awareness, treatment and control of diabetes and impaired fasting glucose in the Southern Cone of Latin America. PLoS One. 2017;12(9): e0183953. https://doi.org/10.1371/journal.pone.0183953.

190. Arredondo A, Azar A, Recamán AL. Diabetes, a global public health challenge with a high epidemiological and economic burden on health systems in Latin America. Glob Public Health. 2018;13(7):780-7. https://doi.org/10.1080/17441692.2017. 1316414.

191. Gagliardino JJ, Olivera EM, Etchegoyen GS, González C, Guidi ML. Evaluation and cost of the health care process of diabetic patients. Medicina (B Aires). 2000;60(6):880-8.

192. Olivera AR, Roesler V, Iochpe C, Schmidt MI, Vigo Á, Barreto $\mathrm{SM}$, et al. Comparison of machine-learning algorithms to build a predictive model for detecting undiagnosed diabetes - ELSABrasil: accuracy study. Sao Paulo Med J. 2017;135(3):234-46. https://doi.org/10.1590/1516-3180.2016.0309010217.

193. Arellano-Campos O, Gómez-Velasco DV, Bello-Chavolla OY, Cruz-Bautista I, Melgarejo-Hernandez MA, Muñoz-Hernandez $\mathrm{L}$, et al. Development and validation of a predictive model for incident type 2 diabetes in middle-aged Mexican adults: the metabolic syndrome cohort. BMC Endocr Disord. 2019;19(1):41. https://doi.org/10.1186/s12902-019-0361-8.

194. Milton EC, Herman WH, Aiello AE, Danielson KR, MendozaAvelarez MO, Piette JD. Validation of a type 2 diabetes screening tool in rural Honduras. Diabetes Care. 2010;33(2):275-7. https:// doi.org/10.2337/dc09-1021.

195. Bernabe-Ortiz A, Perel P, Miranda JJ, Smeeth L. Diagnostic accuracy of the Finnish Diabetes Risk Score (FINDRISC) for 
undiagnosed T2DM in Peruvian population. Prim Care Diabetes. 2018;12(6):517-25. https://doi.org/10.1016/j.pcd.2018.07.015.

196. Muñoz-González MC, Lima-Martínez MM, Nava A, Trerotola G, Paoli M, Cabrera-Rego JO, et al. FINDRISC modified for Latin America as a screening tool for persons with impaired glucose metabolism in Ciudad Bolívar. Venezuela Med Princ Pract. 2019;28(4):324-32. https://doi.org/10.1159/000499468.

197. Nieto-Martínez R, González-Rivas JP, Ugel E, Marulanda MI, Durán M, Mechanick JI, et al. External validation of the Finnish diabetes risk score in Venezuela using a national sample: The EVESCAM. Prim Care Diabetes. 2019;13(6):574-82. https:// doi.org/10.1016/j.pcd.2019.04.006.

198. Carrillo-Larco RM, Aparcana-Granda DJ, Mejia JR, BernabéOrtiz A. FINDRISC in Latin America: a systematic review of diagnosis and prognosis models. BMJ Open Diabetes Res Care. 2020;8(1). https://doi.org/10.1136/bmjdrc-2019-001169.

199. Aschner PM, Muñoz OM, Girón D, García OM, Fernández-Ávila DG, Casas L, et al. Clinical practice guideline for the prevention, early detection, diagnosis, management and follow up of type 2 diabetes mellitus in adults. Colomb Med (Cali). 2016;47(2):109 31.

200. Saxton AT, Miranda JJ, Ortiz EJ, Pan W. Assessment of two diabetes point-of-care analyzers measuring hemoglobin A1c in the Peruvian Amazon. Ann Glob Health. 2018;84(4):618-24. https://doi.org/10.9204/aogh.2368.

201. Valdez-González LA, Méndez-Padrón A, Gómez-Díaz RA, Valladares-Salgado A, Sánchez-Becerra MC, MondragónGonzález R, et al. Agreement between the 'point of care' tests for microalbuminuria and $\mathrm{HbA} 1 \mathrm{c}$ performed in mexican family medicine units and the results of standard laboratory tests. Scand J Clin Lab Invest. 2018;78(1-2):87-93. https://doi.org/10.1080/ 00365513.2017 .1416664

202. Piette JD, Milton EC, Aiello AE, Mendoza-Avelares MO, Herman WH. Comparison of three methods for diabetes screening in a rural clinic in Honduras. Rev Panam Salud Publica. 2010;28(1): 49-57. https://doi.org/10.1590/s1020-49892010000700008.

203. Cortés-Sanabria L, Martínez-Ramírez HR, Hernández JL, RojasCampos E, Canales-Muñoz JL, Cueto-Manzano AM. Utility of the Dipstick Micraltest II in the screening of microalbuminuria of diabetes mellitus type 2 and essential hypertension. Rev Investig Clin. 2006;58(3):190-7.

204. Beran D, Chappuis F, Damasceno A, Jha N, Pesantes MA, Singh $\mathrm{SB}$, et al. High-quality health systems: time for a revolution in research and research funding. Lancet Glob Health. 2019;7(3): e303-e4. https://doi.org/10.1016/s2214-109x(18)30529-1.

205. Plüddemann A, Heneghan C, Price CP, Wolstenholme J, Thompson M. Point-of-care blood test for ketones in patients with diabetes: primary care diagnostic technology update. Br J Gen Pract. 2011;61(589):530-1. https://doi.org/10.3399/ bjgp11X588600.

206. Plüddemann A, Price CP, Thompson M, Wolstenholme J, Heneghan C. Primary care diagnostic technology update: pointof-care testing for glycosylated haemoglobin. Br J Gen Pract. 2011;61(583):139-40. https://doi.org/10.3399/bjgp11X556290.

207. Guzmán JR, Lyra R, Aguilar-Salinas CA, Cavalcanti S, Escaño F, Tambasia M, et al. Treatment of type 2 diabetes in Latin America: a consensus statement by the medical associations of 17 Latin American countries. Latin American Diabetes Association. Rev Panam Salud Publica. 2010;28(6):463-71. https://doi.org/10. 1590/s1020-49892010001200008

208. Silva AD, Rosa T, Batista LE, Kalckmann S, Louvison MCP, Teixeira D, et al. Racial inequities and aging: analysis of the 2010 cohort of the Health, Welfare and Aging Study (SABE). Rev Bras Epidemiol. 2019;21Suppl 02(Suppl 02):e180004. https://doi.org/10.1590/1980-549720180004.supl.2.
209. Lima RF, Fontbonne A, Carvalho EM, Montarroyos UR, Barreto $\mathrm{MN}$, Cesse E. Factors associated with glycemic control in people with diabetes at the Family Health Strategy in Pernambuco. Rev Esc Enferm USP. 2016;50(6):937-45. https://doi.org/10.1590/ s0080-623420160000700009.

210. Aschner P, Gagliardino JJ, Ilkova H, Lavalle F, Ramachandran A, Mbanya JC, et al. Persistent poor glycaemic control in individuals with type 2 diabetes in developing countries: 12 years of realworld evidence of the International Diabetes Management Practices Study (IDMPS). Diabetologia. 2020;63(4):711-21. https://doi.org/10.1007/s00125-019-05078-3.

211. Rivera-Andrade A, Luna MA. Trends and heterogeneity of cardiovascular disease and risk factors across Latin American and Caribbean countries. Prog Cardiovasc Dis. 2014;57(3):276-85. https://doi.org/10.1016/j.pcad.2014.09.004.

212. Chan JC, Gagliardino JJ, Baik SH, Chantelot JM, Ferreira SR, Hancu N, et al. Multifaceted determinants for achieving glycemic control: the International Diabetes Management Practice Study (IDMPS). Diabetes Care. 2009;32(2):227-33. https://doi.org/10. 2337/dc08-0435.

213. Belizan M, Alonso JP, Nejamis A, Caporale J, Copo MG, Sánchez $\mathrm{M}$, et al. Barriers to hypertension and diabetes management in primary health care in Argentina: qualitative research based on a behavioral economics approach. Transl Behav Med. 2019. https:// doi.org/10.1093/tbm/ibz040.

214. Rojas-Martínez R, Basto-Abreu A, Aguilar-Salinas CA, ZárateRojas E, Villalpando S, Barrientos-Gutiérrez T. Prevalence of previously diagnosed diabetes mellitus in Mexico. Salud Publica Mex. 2018;60(3):224-32. https://doi.org/10.21149/8566.

215. Carro GV, Saurral R, Sagüez FS, Witman EL. Diabetic foot among hospitalized patients in Latin America. Medicina (B Aires). 2018;78(4):243-51.

216. Chen-Ku CH, Gonzalez-Galvez G, Vásquez M, Fuente G, Nakazone MA, Silva Giordano AI, et al. Vascular Complications In Patients With Type 2 Diabetes: Prevalence And Comorbidities In 6 Countries of Latin America (a cohort of the discover study program). Endocr Pract. 2019;25(10):994 1002. https://doi.org/10.4158/ep-2018-0473.

217. Parisi MC, Moura Neto A, Menezes FH, Gomes MB, Teixeira RM, de Oliveira JE, et al. Baseline characteristics and risk factors for ulcer, amputation and severe neuropathy in diabetic foot at risk: the BRAZUPA study. Diabetol Metab Syndr. 2016;8:25. https://doi.org/10.1186/s13098-016-0126-8.

218. Laclé A, Valero-Juan LF. Diabetes-related lower-extremity amputation incidence and risk factors: a prospective seven-year study in Costa Rica. Rev Panam Salud Publica. 2012;32(3):192-8. https:// doi.org/10.1590/s1020-49892012000900004.

219. Costa WJT, Penha-Silva N, Bezerra IMP, Paulo Dos Santos I, Ramos JLS, Castro JM, et al. Analysis of Diabetes MellitusRelated Amputations in the State of Espírito Santo, Brazil. Medicina (Kaunas). 2020;56(6). https://doi.org/10.3390/ medicina56060287.

220. Ascencio-Montiel IJ. 10 years analysis of diabetes-related major lower extremity amputations in Mexico. Arch Med Res. 2018;49(1):58-64. https://doi.org/10.1016/j.arcmed.2018.04.005.

221. Bonilla GA, Hornsby PP, Pannone AF, Case SK, Aviles ES, Carrasco Apolinario ME, et al. Demographic and clinical characteristics of dominican adults admitted to a diabetic foot clinic in the Dominican Republic, 2015. Diabetes Metab Syndr. 2019;13(3):1727-32. https://doi.org/10.1016/j.dsx.2019.03.034.

222. Adrianzén RE, Rioja M, Manrique A. Frequency and severity of diabetic retinopathy in patients with type 2 diabetes mellitus at the Regional Institute of Ophthalmology. Rev Peru Med Exp Salud Publica. 2019;36(2):260-4. https://doi.org/10.17843/rpmesp. 2019.362.4076. 
223. Drummond KRG, Malerbi FK, Morales PH, Mattos TCL, Pinheiro AA, Mallmann F, et al. Regional differences in the prevalence of diabetic retinopathy: a multi center study in Brazil. Diabetol Metab Syndr. 2018;10:17. https://doi.org/10.1186/ s13098-018-0319-4.

224. Cusumano AM, González Bedat MC. Chronic kidney disease in Latin America: time to improve screening and detection. Clin J Am Soc Nephrol. 2008;3(2):594-600. https://doi.org/10.2215/cjn. 03420807.

225. Correa-Rotter R, García-Trabanino R. Mesoamerican Nephropathy. Semin Nephrol. 2019;39(3):263-71. https://doi. org/10.1016/j.semnephrol.2019.02.004.

226. González Villalpando C, Stern MP, Arredondo Pérez B, Martínez Díaz S, Islas Andrade S, Revilla C, et al. Nephropathy in low income diabetics: the Mexico City Diabetes Study. Arch Med Res. 1996;27(3):367-72.

227. Correa-Rotter R, González-Michaca L. Early detection and prevention of diabetic nephropathy: a challenge calling for mandatory action for Mexico and the developing world. Kidney Int Suppl. 2005;98:S69-75. https://doi.org/10.1111/j.1523-1755.2005. 09813.x.

228. Valdez-Ortiz R, Navarro-Reynoso F, Olvera-Soto MG, MartinAlemañy G, Rodríguez-Matías A, Hernández-Arciniega CR, et al. Mortality in patients with chronic renal disease without health insurance in Mexico: opportunities for a national renal health policy. Kidney Int Rep. 2018;3(5):1171-82. https://doi. org/10.1016/j.ekir.2018.06.004.

229. Zenteno-Castillo P, Muñoz-López DB, Merino-Reyes B, VegaSánchez Á, Preciado-Puga M, González-Yebra AL, et al. Prevalence of diabetic nephropathy in Type 2 Diabetes Mellitus in rural communities of Guanajuato, Mexico. Effect after 6 months of Telmisartan treatment. J Clin Transl Endocrinol. 2015;2(4): 125-8. https://doi.org/10.1016/j.jcte.2015.08.001.

230. Bachmann MO, Bateman ED, Stelmach R, Cruz ÁA, Pacheco de Andrade M, Zonta R, et al. Integrating primary care of chronic respiratory disease, cardiovascular disease and diabetes in Brazil: Practical Approach to Care Kit (PACK Brazil): study protocol for randomised controlled trials. J Thorac Dis. 2018;10(7):4667-77. https://doi.org/10.21037/jtd.2018.07.34.

231. da Silva Marinho MG, Fontbonne A, Vasconcelos Barbosa JM, de Melo Rodrigues H. Freese de Carvalho E, Vieira de Souza W et al. The impact of an intervention to improve diabetes management in primary healthcare professionals' practices in Brazil. Prim Care Diabetes. 2017;11(6):538-45. https://doi.org/10.1016/j.pcd.2017. 06.002

232. Simão C, Costa MB, Colugnati FAB, de Paula EA, Vanelli CP, de Paula RB. Quality of Care of patients with diabetes in primary health services in Southeast Brazil. J Environ Public Health. 2017;2017:1709807. https://doi.org/10.1155/2017/1709807.

233. Silva-Tinoco R, Cuatecontzi-Xochitiotzi T, De la Torre-Saldaña V, León-García E, Serna-Alvarado J, Guzmán-Olvera E, et al. Role of social and other determinants of health in the effect of a multicomponent integrated care strategy on type 2 diabetes mellitus. Int J Equity Health. 2020;19(1):75. https://doi.org/10. 1186/s12939-020-01188-2.

234. Gallardo-Rincón H, Saucedo-Martínez R, Mujica-Rosales R, Lee EM, Israel A, Torres-Beltran B, et al. Online continuing medical education as a key link for successful noncommunicable disease self-management: the CASALUD ${ }^{\mathrm{TM}}$ Model. Diabetes Metab Syndr Obes. 2017;10:443-55. https://doi.org/10.2147/dmso. S137891.

235. Lew KN, McLean Y, Byers S, Taylor H, Braizat OM. Combined diabetes prevention and disease self-management intervention for Nicaraguan ethnic minorities: a pilot study. Prog Community Health Partnersh. 2017;11(4):357-66. https://doi.org/10.1353/ cpr.2017.0043.
236. Batista F, Augusto Magalhães A, Gamba M, Nery C, Cardoso C. Ten years of a multidisciplinary diabetic foot team approach in Sao Paulo. Brazil Diabet Foot Ankle. 2010;1. https://doi.org/10. 3402/dfa.v1i0.5203.

237. Barceló A, Cafiero E, de Boer M, Mesa AE, Lopez MG, Jiménez RA, et al. Using collaborative learning to improve diabetes care and outcomes: the VIDA project. Prim Care Diabetes. 2010;4(3): 145-53. https://doi.org/10.1016/j.pcd.2010.04.005.

238. Lerario AC, Chacra AR, Pimazoni-Netto A, Malerbi D, Gross JL, Oliveira JE, et al. Algorithm for the treatment of type 2 diabetes: a position statement of Brazilian Diabetes Society. Diabetol Metab Syndr. 2010;2(1):35. https://doi.org/10.1186/1758-5996-2-35.

239. Piette JD, Marinec N, Gallegos-Cabriales EC, Gutierrez-Valverde JM, Rodriguez-Saldaña J, Mendoz-Alevares M, et al. Spanishspeaking patients' engagement in interactive voice response (IVR) support calls for chronic disease self-management: data from three countries. J Telemed Telecare. 2013;19(2):89-94. https://doi.org/10.1177/1357633x13476234.

240. Piette JD, Mendoza-Avelares MO, Ganser M, Mohamed M, Marinec N, Krishnan S. A preliminary study of a cloudcomputing model for chronic illness self-care support in an underdeveloped country. Am J Prev Med. 2011;40(6):629-32. https:// doi.org/10.1016/j.amepre.2011.02.014.

241. Piette JD, Marinec N, Janda K, Morgan E, Schantz K, Yujra AC, et al. Structured caregiver feedback enhances engagement and impact of mobile health support: a randomized trial in a lowermiddle-income country. Telemed J E Health. 2016;22(4):261-8. https://doi.org/10.1089/tmj.2015.0099.

242. Piette JD, Valverde H, Marinec N, Jantz R, Kamis K, de la Vega $\mathrm{CL}$, et al. Establishing an independent mobile health program for chronic disease self-management support in bolivia. Front Public Health. 2014;2:95. https://doi.org/10.3389/fpubh.2014.00095.

243. Prestes M, Gayarre MA, Elgart JF, Gonzalez L, Rucci E, Paganini $\mathrm{JM}$, et al. Improving diabetes care at primary care level with a multistrategic approach: results of the DIAPREM programme. Acta Diabetol. 2017;54(9):853-61. https://doi.org/10.1007/ s00592-017-1016-8.

244. Flood D, Mux S, Martinez B, García P, Douglas K, Goldberg V, et al. Implementation and outcomes of a comprehensive type 2 diabetes program in rural Guatemala. PLoS One. 2016;11(9): e0161152. https://doi.org/10.1371/journal.pone.0161152.

245. Flood D, Douglas K, Goldberg V, Martinez B, Garcia P, Arbour $\mathrm{M}$, et al. A quality improvement project using statistical process control methods for type 2 diabetes control in a resource-limited setting. Int J Qual Health Care. 2017;29(4):593-601. https://doi. org/10.1093/intqhe/mzx051.

246. Flood D, Hawkins J, Rohloff P. A home-based type 2 diabetes self-management intervention in rural Guatemala. Prev Chronic Dis. 2017;14:E65. https://doi.org/10.5888/pcd14.170052.

247. Tapia-Conyer R, Gallardo-Rincón H, Saucedo-Martinez R. CASALUD: an innovative health-care system to control and prevent non-communicable diseases in Mexico. Perspect Public Health. 2015;135(4):180-90. https://doi.org/10.1177/ 1757913913511423.

248. Salamanca O, Geary A, Suárez N, Benavent S, Gonzalez M. Implementation of a diabetic retinopathy referral network. Peru Bull World Health Organ. 2018;96(10):674-81. https://doi.org/ 10.2471/blt.18.212613.

249. Avendaño-Veloso A, Parada-Hernández F, González-Ramos R, Dougnac-Osses C, Carrasco-Sáez JL, Scanlon PH. Teleophthalmology: a strategy for timely diagnosis of sightthreatening diabetic retinopathy in primary care, Concepción, Chile. Int J Ophthalmol. 2019;12(9):1474-8. https://doi.org/10. 18240/ijo.2019.09.16.

250. Flores R, Donoso R, Anguita R. Management of diabetic retinopathy using telemedicine and network integration. Rev Med Chil. 
2019;147(4):444-50. https://doi.org/10.4067/s003498872019000400444.

251. Cani CG, Lopes Lda S, Queiroz M, Nery M. Improvement in medication adherence and self-management of diabetes with a clinical pharmacy program: a randomized controlled trial in patients with type 2 diabetes undergoing insulin therapy at a teaching hospital. Clinics (Sao Paulo). 2015;70(2):102-6. https://doi.org/ 10.6061/clinics/2015(02)06.

252. Gagliardino JJ, Lapertosa S, Pfirter G, Villagra M, Caporale JE, Gonzalez CD, et al. Clinical, metabolic and psychological outcomes and treatment costs of a prospective randomized trial based on different educational strategies to improve diabetes care (PRODIACOR). Diabet Med. 2013;30(9):1102-11. https://doi. org/10.1111/dme.12230.

253. Beauregard D, Schiffman JS, Tang R. Collaborative telemedicine between optometry and ophthalmology: an initiative from the University of Houston. Stud Health Technol Inform. 1999;64: 173-8.

254. Villena JE, Yoshiyama CA, Sánchez JE, Hilario NL, Merin LM. Prevalence of diabetic retinopathy in Peruvian patients with type 2 diabetes: results of a hospital-based retinal telescreening program. Rev Panam Salud Publica. 2011;30(5):408-14.

255. Jiménez-Ramírez F, Pérez R. Diabetic retinopathy education and screening at the community pharmacy in Puerto Rico. P R Health Sci J. 2011;30(3):139-44.

256. Acevedo Castellón RI, Carranza Vargas E, Cortés Chavarría RE, Rodríguez Vargas GA. Rapid assessment of avoidable blindness and diabetic retinopathy in individuals aged 50 years or older in Costa Rica. PLoS One. 2019;14(2):e0212660. https://doi.org/10. 1371/journal.pone.0212660.

257. Ministerio de Salud de Argentina. Encuesta Rapida de Ceguera Evitable, Argentina, 2013 (http://www.msal.gob.ar/images/ stories/bes/graficos/0000000603cnt-2015-01_encuesta-rapidaceguera-evitable.pdf) Argentina2013. [Last Accessed on August $6,2020]$.

258. Limburg H, Espinoza R, Lansingh VC, Silva JC. Functional low vision in adults from Latin America: findings from populationbased surveys in 15 countries. Rev Panam Salud Publica. 2015;37(6):371-8.

259. Polack S, Yorston D, López-Ramos A, Lepe-Orta S, Baia RM, Alves L, et al. Rapid assessment of avoidable blindness and diabetic retinopathy in Chiapas. Mexico Ophthalmology. 2012;119(5):1033-40. https://doi.org/10.1016/j.ophtha.2011.11. 002 .

260. Martinez J, Hernandez-Bogantes E, Wu L. Diabetic retinopathy screening using single-field digital fundus photography at a district level in Costa Rica: a pilot study. Int Ophthalmol. 2011;31(2): 83-8. https://doi.org/10.1007/s10792-010-9413-9.

261. Mendoza-Herrera K, Quezada AD, Pedroza-Tobías A, Hernández-Alcaraz C, Fromow-Guerra J, Barquera S. A Diabetic Retinopathy Screening Tool for Low-Income Adults in Mexico. Prev Chronic Dis. 2017;14:E95. https://doi.org/10.5888/ pcd14.170157.

262. Lazo-Porras M, Bernabe-Ortiz A, Sacksteder KA, Gilman RH, Malaga G, Armstrong DG, et al. Implementation of foot thermometry plus mHealth to prevent diabetic foot ulcers: study protocol for a randomized controlled trial. Trials. 2016;17(1):206. https:// doi.org/10.1186/s13063-016-1333-1.

263. Jimenez MM, Bui AL, Mantilla E, Miranda JJ. Human resources for health in Peru: recent trends (2007-2013) in the labour market for physicians, nurses and midwives. Hum Resour Health. 2017;15(1):69. https://doi.org/10.1186/s12960-017-0243-y.
264. Emmerick IC, Luiza VL, Camacho LA, Vialle-Valentin C, RossDegnan D. Barriers in household access to medicines for chronic conditions in three Latin American countries. Int J Equity Health. 2015;14:115. https://doi.org/10.1186/s12939-015-0254-z.

265. Esterson YB, Carey M, Piette JD, Thomas N, Hawkins M. A systematic review of innovative diabetes care models in low-and middle-income countries (LMICs). J Health Care Poor Underserved. 2014;25(1):72-93. https://doi.org/10.1353/hpu. 2014.0037.

266. Maia LG, Silva LAD, Guimarães RA, Pelazza BB, Leite GR, Barbosa MA. The quality of primary care services, vocational training and the More Doctors Program in a health region of southwest Goiás. Rev Bras Epidemiol. 2020;23:e200014. https:// doi.org/10.1590/1980-549720200014.

267. Butte NF, Cai G, Cole SA, Comuzzie AG. Viva la Familia Study: genetic and environmental contributions to childhood obesity and its comorbidities in the Hispanic population. Am J Clin Nutr. 2006;84(3):646-54; quiz 73-4. https://doi.org/10.1093/ajcn/84.3. 646.

268. Pinney SE, Joshi A, Yin V, Min SW, Rashid C, Condon DE, et al. Exposure to gestational diabetes enriches immune related pathways in the transcriptome and methylome of human amniocytes. J Clin Endocrinol Metab. 2020. https://doi.org/10.1210/clinem/ dgaa466.

269. Gómez Dantés H, Castro MV, Franco-Marina F, Bedregal P, Rodríguez García J, Espinoza A, et al. Burden of disease in Latin America. Salud Publica Mex. 2011;53(Suppl 2):s72-7.

270. Tejero ME. Cardiovascular disease in Latin American women. Nutr Metab Cardiovasc Dis. 2010;20(6):405-11. https://doi.org/ 10.1016/j.numecd.2010.02.005.

271. Bozanic A, Toro P, Formiga F. DIABDEM project: a pilot study of prevalence of cognitive impairment in diabetes mellitus in 2 Hispanic countries. Rev Esp Geriatr Gerontol. 2019;54(6):339 45. https://doi.org/10.1016/j.regg.2019.04.004.

272. Goveas JS, Rapp SR, Hogan PE, Driscoll I, Tindle HA, Smith JC, et al. Predictors of optimal cognitive aging in $80+$ women: the Women's Health Initiative Memory Study. J Gerontol A Biol Sci Med Sci. 2016;71 Suppl 1(Suppl 1):S62-71. https://doi.org/ 10.1093/gerona/glv055.

273. Bernard L, Reix N, Benabu JC, Gabriele V, Mathelin C. Breast cancer and diabetes mellitus: complex interactions. Gynecol Obstet Fertil. 2016;44(12):701-11. https://doi.org/10.1016/j. gyobfe.2016.09.004.

274. Overbeek JA, Kuiper JG, van der Heijden A, Labots M, Haug U, Herings RMC, et al. Sex- and site-specific differences in colorectal cancer risk among people with type 2 diabetes. Int J Color Dis. 2019;34(2):269-76. https://doi.org/10.1007/s00384-018-3191-7.

275. Pérez C, Ailshire JA. Aging in Puerto Rico: A Comparison of Health Status Among Island Puerto Rican and Mainland U.S. Older Adults. J Aging Health. 2017;29(6):1056-78. https://doi. org/10.1177/0898264317714144.

276. Lundeen EA, Wittenborn J, Benoit SR, Saaddine J. Disparities in receipt of eye exams among medicare part B fee-for-service beneficiaries with diabetes - United States, 2017. MMWR Morb Mortal Wkly Rep. 2019;68(45):1020-3. https://doi.org/10. 15585/mmwr.mm6845a3.

277. Louvison MC, Lebrão ML, Duarte YA, Santos JL, Malik AM, Almeida ES. Inequalities in access to health care services and utilization for the elderly in São Paulo, Brazil. Rev Saude Publica. 2008;42(4):733-40. https://doi.org/10.1590/s003489102008000400021.

278. Cataife G. Public versus private treatment of chronic diseases in seniors: Argentina, Brazil. Chile and Uruguay Glob Public Health. 
2012;7(10):1157-69. https://doi.org/10.1080/17441692.2012. 721894 .

279. Rodríguez-Vigil E, Kianes-Pérez Z. Quality of care provided to patients with diabetes mellitus in Puerto Rico; managed care versus fee-for-service experience. Endocr Pract. 2005;11(6):376-81. https://doi.org/10.4158/ep.11.6.376.

280. Hoogendijk EO, Rijnhart JJM, Kowal P, Pérez-Zepeda MU, Cesari M, Abizanda P, et al. Socioeconomic inequalities in frailty among older adults in six low- and middle-income countries: results from the WHO Study on global AGEing and adult health (SAGE). Maturitas. 2018;115:56-63. https://doi.org/10.1016/j. maturitas.2018.06.011.

281. Whittemore R, Vilar-Compte M, De La Cerda S, Marron D, Conover R, Delvy R, et al. Challenges to diabetes selfmanagement for adults with type 2 diabetes in low-resource settings in Mexico City: a qualitative descriptive study. Int J Equity Health. 2019;18(1):133. https://doi.org/10.1186/s12939-0191035-x.

282. Gallegos-Carrillo K, García-Peña C, Durán-Muñoz CA, Flores YN, Salmerón J. Relationship between social support and the physical and mental wellbeing of older Mexican adults with diabetes. Rev Investig Clin. 2009;61(5):383-91.

283. Briceño I, Barriocanal LA, Papiha SS, Ashworth LA, Gómez A, Bernal JE, et al. Lack of diabetes in rural Colombian Amerindians. Diabetes Care. 1996;19(8):900-1. https://doi.org/10.2337/diacare. 19.8.900.

284. Alvarado-Osuna C, Milian-Suazo F, Valles-Sánchez V. Prevalence of diabetes mellitus and hyperlipidemia among Otomi indians. Salud Publica Mex. 2001;43(5):459-63.

285. Guerrero-Romero F, Rodríguez-Morán M, Sandoval-Herrera F. Low prevalence of non-insulin-dependent diabetes mellitus in indigenous communities of Durango. Mexico Arch Med Res. 1997;28(1):137-40.

286. Barbosa CC, Sacuena ESR, Pinto AM, Cardoso-Costa GL, Guerreiro JF. Anthropometric and metabolic profile of a Brazilian Amerindian group: The Xikrin (Mebengôkre). Am J Hum Biol. 2019;31(4):e23255. https://doi.org/10.1002/ajhb. 23255.

287. Breathett K, Sims M, Gross M, Jackson EA, Jones EJ, NavasAcien A, et al. Cardiovascular health in American Indians and Alaska Natives: a scientific statement from the American Heart Association. Circulation. 2020;141(25):e948-e59. https://doi.org/ 10.1161/cir.0000000000000773.

288. Walker JD, Slater M, Jones CR, Shah BR, Frymire E, Khan S, et al. Diabetes prevalence, incidence and mortality in First Nations and other people in Ontario, 1995-2014: a population-based study using linked administrative data. Cmaj. 2020;192(6):E128-e35. https://doi.org/10.1503/cmaj.190836.

289. de Souza Filho ZA, Ferreira AA, Dos Santos J, Meira KC, Pierin AMG. Cardiovascular risk factors with an emphasis on hypertension in the Mura Indians from Amazonia. BMC Public Health. 2018;18(1):1251. https://doi.org/10.1186/s12889-018-6160-8.

290. Rodríguez-Morán M, Guerrero-Romero F, Brito-Zurita O, Rascón-Pacheco RA, Pérez-Fuentes R, Sánchez-Guillén MC, et al. Cardiovascular risk factors and acculturation in Yaquis and Tepehuanos Indians from Mexico. Arch Med Res. 2008;39(3): 352-7. https://doi.org/10.1016/j.arcmed.2007.12.003.

291. Alvim Rde O, Mourao-Junior CA, de Oliveira CM, Krieger JE, Mill JG, Pereira AC. Body mass index, waist circumference, body adiposity index, and risk for type 2 diabetes in two populations in Brazil: general and Amerindian. PLoS One. 2014;9(6):e100223. https://doi.org/10.1371/journal.pone.0100223.
292. Lindgärde F, Widén I, Gebb M, Ahrén B. Traditional versus agricultural lifestyle among Shuar women of the Ecuadorian Amazon: effects on leptin levels. Metabolism. 2004;53(10): 1355-8. https://doi.org/10.1016/j.metabol.2004.04.012.

293. Baldoni NR, Aquino JA, Alves GCS, Sartorelli DS, Franco LJ, Madeira SP, et al. Prevalence of overweight and obesity in the adult indigenous population in Brazil: a systematic review with meta-analysis. Diabetes Metab Syndr. 2019;13(3):1705-15. https://doi.org/10.1016/j.dsx.2019.03.024.

294. Araujo M, Moraga C, Chapman E, Barreto J, Illanes E. Interventions to improve access to health services by indigenous peoples in the Americas. Rev Panam Salud Publica. 2016;40(5): 371-81.

295. Chary A, Greiner M, Bowers C, Rohloff P. Determining adult type 2 diabetes-related health care needs in an indigenous population from rural Guatemala: a mixed-methods preliminary study. BMC Health Serv Res. 2012;12:476. https://doi.org/10.1186/14726963-12-476.

296. de Alencar R, Galvao TF, Antonio BVR, Silva MT. Prevalence of Self-Reported Chronic Diseases and Health Services Utilization by Ethnic Minorities in Manaus Metropolitan Region. Ethn Dis. 2018;28(1):49-54. https://doi.org/10.18865/ed.28.1.49.

297. Guevara PE, Andrade FC. Socioeconomic and lifestyle factors associated with chronic conditions among older adults in Ecuador. Rev Panam Salud Publica. 2015;38(3):226-32.

298. Harding T, Oetzel J. Implementation effectiveness of health interventions for indigenous communities: a systematic review. Implement Sci. 2019;14(1):76. https://doi.org/10.1186/s13012019-0920-4.

299. Micikas M, Foster J, Weis A, Lopez-Salm A, Lungelow D, Mendez P, et al. A community health worker intervention for diabetes self-management among the Tz'utujil Maya of Guatemala. Health Promot Pract. 2015;16(4):601-8. https://doi. org $/ 10.1177 / 1524839914557033$.

300. Nieblas-Bedolla E, Bream KDW, Rollins A, Barg FK. Ongoing challenges in access to diabetes care among the indigenous population: perspectives of individuals living in rural Guatemala. Int $\mathrm{J}$ Equity Health. 2019;18(1):180. https://doi.org/10.1186/s12939019-1086-Z

301. Coimbra CE Jr, Santos RV, Welch JR, Cardoso AM, de Souza $\mathrm{MC}$, Garnelo L, et al. The first national survey of indigenous people's health and nutrition in Brazil: rationale, methodology, and overview of results. BMC Public Health. 2013;13:52. https://doi.org/10.1186/1471-2458-13-52.

302. Mirassou CS. Health system and aboriginal communities in the province of Formosa, Argentina. Medicina (B Aires). 2013;73(5): 453-6.

303. Rashak HA, Sánchez-Pérez HJ, Abdelbary BE, Bencomo-Alerm A, Enriquez-Ríos N, Gómez-Velasco A, et al. Diabetes, undernutrition, migration and indigenous communities: tuberculosis in Chiapas. Mexico Epidemiol Infect. 2019;147:e71. https://doi. org/10.1017/s0950268818003461.

304. Céspedes C, López L, Aguirre S, Mendoza-Ticona A. Prevalence of comorbidity tuberculosis and diabetes mellitus in Paraguay, 2016 and 2017Prevalência de comorbidade tuberculose-diabetes mellitus no Paraguai, 2016 e 2017. Rev Panam Salud Publica. 2019;43:e105. https://doi.org/10.26633/rpsp.2019.105.

305. Nascimento CV, Soares SM. Co-management of tuberculosis and diabetes: an integrative reviewManejo integrado de la tuberculosis y la diabetes: revisión integrativa. Rev Panam Salud Publica. 2019;43:e21. https://doi.org/10.26633/rpsp.2019.21. 
306. Pablos-Méndez A, Vega J, Aranguren FP, Tabish H, Raviglione MC. Covid-19 in Latin America. Bmj. 2020;370:m2939. https:// doi.org/10.1136/bmj.m2939.

307. Barone MTU, Harnik SB, de Luca PV, Lima BLS, Wieselberg RJP, Ngongo B, et al. The impact of COVID-19 on people with diabetes in Brazil. Diabetes Res Clin Pract. 2020;166:108304. https://doi.org/10.1016/j.diabres.2020.108304.

308. Bello-Chavolla OY, González-Díaz A, Antonio-Villa NE, Fermín-Martínez CA, Márquez-Salinas A, Vargas-Vázquez A, et al. Unequal impact of structural health determinants and comorbidity on COVID-19 severity and lethality in older Mexican adults: Considerations beyond chronological aging. J Gerontol A Biol Sci Med Sci. 2020. https://doi.org/10.1093/gerona/ glaa163.

309. Barone MTU, Villarroel D, de Luca PV, Harnik SB, Lima BLS, Wieselberg RJP, et al. COVID-19 impact on people with diabetes in South and Central America (SACA region). Diabetes Res Clin
Pract. 2020;166:108301. https://doi.org/10.1016/j.diabres.2020. 108301.

310. Díaz de León-Martínez L, de la Sierra-de la Vega L, PalaciosRamírez A, Rodriguez-Aguilar M, Flores-Ramírez R. Critical review of social, environmental and health risk factors in the Mexican indigenous population and their capacity to respond to the COVID-19. Sci Total Environ. 2020;733:139357. https://doi. org/10.1016/j.scitotenv.2020.139357.

311. Teles M, Sacchetta T, Matsumoto Y. COVID-19 Pandemic Triggers Telemedicine Regulation and Intensifies Diabetes Management Technology Adoption in Brazil. J Diabetes Sci Technol. 2020;14(4):797-8. https://doi.org/10.1177/ 1932296820930033.

Publisher's Note Springer Nature remains neutral with regard to jurisdictional claims in published maps and institutional affiliations. 